\title{
VIRTUS CORONATA EX AUGUSTISSIMA \\ ET SERENISSIMA DOMO AUSTRIACA ET \\ HISPANA.* EL RETRATO ECUESTRE COMO \\ SÍMBOLO DE LA CASA DE AUSTRIA
}

„VIRTUS CORONATA EX AUGUSTISSIMA

ET SERENISSIMA DOMO AUSTRIACA

ET HISPANA“:*: DAS REITERPORTRÄT

ALS HERRSCHAFTSZEICHEN DER HABSBURGER

\author{
VIRTUS CORONATA EX AUGUSTISSIMA \\ ET SERENISSIMA DOMO AUSTRIACA ET HISPANA. \\ THE EQUESTRIAN PORTRAIT AS A SYMBOL \\ OF THE HOUSE OF HABSBURG
}

FRIEDRICH POLLEROß

Universität Wien

Recibido: 23/09/2021 Evaluado: 03/12/2021 Aprobado: 10/01/2022

RESUMEN: El trabajo ofrece una visión sobre el uso de los retratos ecuestres en el contexto de la representación de ambas líneas de la Casa de Austria. Hay muchos estudios sobre el retrato ecuestre de los reyes españoles en el siglo XVII, pero pocos se ocupan del fenómeno en la corte de la rama austriaca de la familia. En efecto, ya existía una escultura ecuestre de Rodolfo I en la catedral de Estrasburgo, y el monumento

*Versión abreviada en latín del título del libro del jesuita Juan Eusebio Nieremberg, publicado originalmente en 1643 en Madrid en castellano y del cual apareció en 1675 en Viena una traducción al alemán.

** Verkürzte Version des lateinischen Titels des Buches des Jesuiten Juan Eusebio Nieremberg, das ursprünglich 1643 in Madrid in spanischer Sprache und 1675 in Wien in lateinischer Übersetzung erschienen ist. 
ecuestre del archiduque Leopoldo V sobre un caballo levantado en Innsbruck era anterior a la escultura de Felipe IV en Madrid. Con la ayuda de algunas fuentes icónicas poco utilizadas en este contexto se ha podido subrayar la función de los retratos ecuestres en el Salón de los Espejos del Alcázar y en el Salón de Reinos del palacio del Buen Retiro como Salas de Virtudes Principescas y como espejo principesco para el Infante. También parece posible que el rey Fernando III y su cuñado el rey Felipe IV tras el triunfo en la batalla de Nördlingen tuvieran la idea de una estrategia común de representación para la Casa de Austria, y que Pedro Pablo Rubens tuviera algún papel en ello.

Palabras clave: Retrato ecuestre, Alcázar, Buen Retiro, Peter Paul Rubens, Diego Velázquez

Zusammenfassung: Der Aufsatz bietet einen Überblick über die Verwendung des Reiterporträts im Rahmen der Repräsentation der Casa de Austria. Zwar wurde bereits viel über Reiterbildnisse der spanischen Könige des 17. Jahrhunderts, insbesondere jene von Diego Velázquez publiziert. Aber der Zusammenhang mit der Tradition dieses Typus bei der österreichischen Linie der Habsburger wurde bisher kaum beleuchtet. So gab es bereits eine Reiterstatue von Rudolph I. am Straßburger Münster, und auch das bronzene Reiterstandbild des Erz herzog Leopold V. auf steigendem Pferd in Innsbruck ging jenem von Philipp IV. in Madrid voraus. Aufgrund der Einbeziehung von einigen in diesem Zusammenhang bisher kaum beachteten Bildquellen wird die Rolle der Portraitserien im Salón de los Espejos des Alcázar und im Salón de Reinos des Buen Retiro als Füstenspiegel für die Infanten betont. Außerdem scheint es naheliegend, dass König Ferdinand III. und sein Schwager König Philipp IV. nach dem Triumph von Nördlingen eine gemeinsame ikonologische Strategie der Casa de Austria verfolgten, und auch Peter Paul Rubens darauf einen Einfluss gehabt haben könnte.

Schlüsselwörter: Reiterporträt, Alcázar, Buen Retiro, Peter Paul Rubens, Diego Velázquez

ABSTRACT: The paper offers an overlook about the use of equestrian portraits in the context of the representation of both lines of the Casa de Austria. There are many studies about the equestrian portrait of the Spanish kings in the 17th century, but few look after the pheno- 
men at the court of the Austrian branch of the family. Indeed, there was already an equestrian sculpture of Rudolph I at the cathedral of Strasbourg, and the equestrian monument of Archduke Leopold V on a rising horse in Innsbruck was earlier than the sculpture of Philippe IV in Madrid. With the help of some in this context not very used iconic sources it was possible to underline the function of the equestrian portraits in the Salón de los Espejos of the Alcázar and in the Salón de Reinos of the Buen Retiro palace as Halls of Princely Virtues and as a prince mirror for the Infant. It seems also possible that King Ferdinand III and his brother-in-law King Philippe IV had the idea of a common strategy of representation for the Casa de Austria after the triumph in the battle of Nördlingen, and that Peter Paul Rubens played some part in it.

Key words: Equestrian portrait, Alcázar, Buen Retiro, Peter Paul Rubens, Diego Velázquez

Desde que fuera proclamado Emperador Romano en Trento en 1508, Maximiliano I venía trayéndose la idea de una estatua ecuestre que tomara como modelo la de Marco Aurelio sobre el Capitolio de Roma. El monumento, diseñado por Hans Burgkmaier «El Viejo», según la apreciación del humanista Konrad Peutinger, combinaba la antigua representación de la Gloria, con la función de representar al donante y a la memoriae cristiana. ${ }^{1}$ El epitaphium fue levantado en un coro que financió Maximiliano para la Basílica de San Ulrico y Santa Afra en Augsburgo. La ejecución se le confió a Gregor Erhart, aunque el monumento quedaría inconcluso. ${ }^{2} \mathrm{Al}$ Habsburgo no solamente se le señala en la inscripción como Imperator Caesar, sino que además se le representa tanto con la corona imperial como con el orbe, lo que hace referencia al monumento imperial romano. Por otra parte, la espada en alto hace alusión a la porfía de Maximiliano como Protector de la Cristiandad.

Lo más importante del monumento ecuestre augsburgués se dice en el Fuggerschen Ehrenspiegel (Espéculo de Honores de Fugger) de Clemens Jäger,

1. Acerca de este género artístico, v. Joachim Poeschke, Thomas Weigel, Britta KuschARnhold (coords.): Reiter-standbilder von der Antike bis zum Klassizismus (Praemium Virtutis III), Münster: Rhema, 2008; Ulrich Keller: «Reiterstandbild» (art.), en Uwe Flecker, Martin Warnke, Hendrik Ziegler (eds.): Politische Ikonographie. Ein Hand-buch, Múnich: C.H. Beck, 2014, vol. 2, 2a ed., pp. 301-307. El texto ha sido traducido por Christian Blanco Fernández.

2. Eva Michel, Maria Luise Sternath (coords.): Kaiser Maximilian I. und die Kunst der Dürerzeit, Múnich: Prestel, 2012, pp. 348-355 (cat. exp.); HeIdrun LANGE-KRACH (ed.): Maximilian I. 1459-1519. Kaiser, Ritter, Bürger zu Augsburg, Regensburg: Schnell \& Steiner, 2019, (cat. exp,), pp. 296-297. 
de mediados del siglo XVI. Y dado que además en esta obra se habla de un monumento ecuestre a Rodolfo I (Fig. 1), quizá también pueda suponerse que esta estatua con una espada levantada inspirara a Maximiliano I. Los ciudadanos de Estrasburgo la habían erigido en su honor sobre la Plaza del Mercado de la ciudad como agradecimiento por el apoyo en la lucha contra el obispo en favor de las libertades de la ciudad: «Rodolfo y los Habsburgo [!] género de una eterna memoria, un bello epitafio, a saber, un gran caballo en alza, sobre él un escudado rey con una desenvainada y levantada espada» y la inscripción reza: «Rudolpho Victorioso Comiti in Habspurg. S.P.Q. Argentinens. Praefect. Strenno, Statuam hanc Equest. pp. M.CCLXVI». ${ }^{3}$

La versión impresa de esta obra en nombre del emperador Leopoldo I publicada en 1668 también añade que el monumento no solo se había remontado a la tradición de los monumentos romanos, sino que además «auspiciaba» la majestad imperial de Rodolfo I y sus descendientes:

Los ciudadanos de Estrasburgo/que con su memoria y ejemplo a los descendientes muestra su agradecimiento/luego de cuatro años/"Rudolpho" como su salvador y protector/una obra de honor o "Statuam" en su ciudad han erigido/a saber, la imagen coronada de un jinete a caballo/con una espada desenvainada/tallada en piedra/y con ella una firma [...]. Esto no tiene la fama del héroe/cuando está tallado en piedra:/el mármol puede aplastar el tiempo/ Las piedras no permanecen para siempre./Rodolfo tiene una columna de honor para sí mismo:/porque la Casa de Habsburgo [Ostenhaus] aún deja ver su virtud. En esta pieza, la loable corte y la ciudadanía de Estrasburgo han imitado a los romanos/ que solían dedicar públicamente tales estatuas, ecuestres o columnas de jinetes, a sus merecidos señores de la guerra: sobre los cuales puede leerse de Lazio y Rosino. Pero al honrar a nuestro Rudolphum a la moda romana/con ignorancia, por así decirlo, establecieron un presagio/ que la corona romana algún día la heredaría él y sus descendientes. ${ }^{4}$

3. El «Ehrenspiegel des Hauses Österreich» se encuentra en la Biblioteca Estatal de Baviera (BSB), Clm. 895, folio 97v.

4. El texto original en alemán: «Die Burger zu Straßburg/ damit sie ein gedächtniß und beyspiel der dankbarkeit den Nachkommen hinterliessen/ liessen vier Jahre hernach/ ,Rudolpho' als ihrem Erlöser und Schutzherrn/ ein Ehrenbild oder ,Statuam' in ihrer Stadt aufrichten/ nämlich die gekrönte Bildniß eines Ritters zu Pferd/ mit gezuck -tem Schwerd/ aus Stein gehauen/ samt einer Unterschrifft [...], Diß hält nicht der Helden Ruhm/ wann er steht in Stein gehauen:/ Marmor kan die Zeit zermalmen/ Steine stehn ewig nicht./ Rudolf eine Ehrenseule ihm hat selber zugericht:/ weil sein ewigs Ostenhaus seine Tugend noch lässt schauen. In diesem stuck haben der löbliche Raht und Bürgerschafft zu Straßburg den Römern nachgeahmet/ welche ihren wolverdienten Kriegsfürsten dergleichen Statuas Equestres oder Ritterseulen offentlich zu widmen pflegten: wovon beym Lazio und Rosino zu lesen ist. Sie haben aber auch dadurch/indem sie unsern Rudolphum auf Römisch geehret/ unwissend gleichsam ein Vorzeichen aufgestellet/ daß die Römische Kron dermaleinst auf ihn und seine Nachkommen erben würde» ( $N$. del T.). v. Sigismund von BirKen: Spiegel der Ehren des Höchstlöblichen Kayser=und Königlichen Ertzhauses Österreich [...], Núremberg: Michael und Johann Friedrich Endter, 1668, pp. 62-64. 


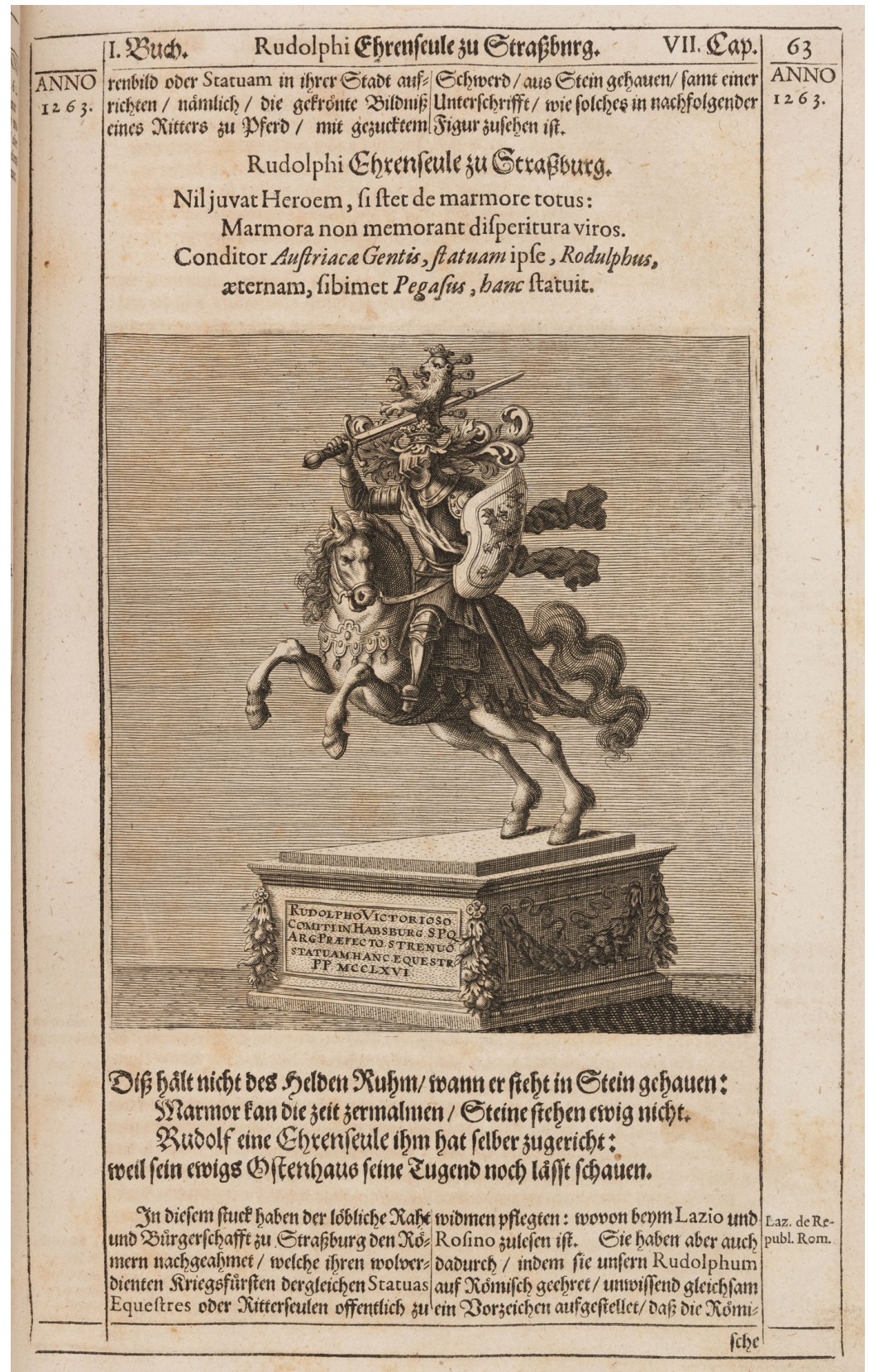

Fig. 1. Monumento ecuestre del emperador Rodolfo I en Strasburgo de 1263 o 1266, Philipp Kilian, (?), grabado en cobre, en: op. cit., Sigismund von Birken, Colección Friedrich Polleroß 
Ambas líneas familiares ya se habían remitido a esta forma de representación a principios del siglo XVII. Sin embargo, se trata de esculturas monumentales que no se erigieron en una plaza pública, sino en un jardín residencial. Son los casos del monumento al archiduque Leopoldo I de Caspar de Gras en Innsbruck, empezado en 1625 (Fig. 2) ${ }^{5}$ y no pudiendo acabarse debido a la temprana muerte del donante, y la escultura ecuestre a Felipe III que llevaron a cabo Giambologna y Pietro Tacca en 1606-1616 en el Real Jardín de la Casa de Campo. ${ }^{6}$ En 1634-1640 y siguiendo la pintura de Velázquez, apareció el monumento al rey Felipe IV de Tacca en el Palacio del Jardín del Buen Retiro que es, al contrario que el monumento ecuestre insbruqués que no le hace a esta justicia alguna, la primera estatua con la dificultosa representación técnica de un caballo en alza (Fig. 3). ${ }^{7}$ Por otra parte, es un hecho digno de mención, que tanto el soberano tirolés, que luchaba en España contra los protestantes, como el rey español, fueran retratados como mariscales de campo y con vestimenta militar y el bastón de mando.

Luego de los monumentos tridimensionales y sus diversos focos de influencia políticos y $\operatorname{artísticos}^{8}$ que han recibido tanta atención en la investigación, como las pinturas españolas de este tipo, ${ }^{9}$ se ofrecerá aquí una descripción comparativa del uso de este en las cortes de Viena y de Madrid, y la

5. Walter Liedtie: The Royal Horse and Rider. Painting, Sculpture and Horsemanship 15001800, Nueva York: Abaris Books, 1989, pp. 212-213, il. 76; Artur RosenAuER (ed.): Spätmittelalter und Renaissance (Geschichte der bildenden Kunst in Österreich 3), Múnich: Prestel 2003, p. 393, NC 186 (Cornelia Plieger); Thomas Kuster: Hoch zu Ross. Das Reiterstandbild Erzherzog Leopolds V.. cat. exp. Innsbruck, Viena: Kunsthistorisches Museum 2020.

6. Katharine Watson: Pietro Tacca. Successore to Giovanni Bologna, Londres: Garland Publishing, 1983, pp. 226-260; Franca Falletti (ed.): Pietro Tacca. Carrara, la Toscana, le grandi corti europee, Carrara: Mandragora, 2007, pp. 54-73 y NC 18 (cat. exp.). Acerca de la procedencia artística y política de la tradicición del monumento, véase: Jessica MACK-AndRICK: Pietro Tacca. Hofbildhauer der Medici (1577-1640). Politische Funktion und Ikonographie des frühabsolutistischen Herrscherdenkmals unter den Großherzögen Ferdinando I., Cosimo II. und Ferdinando II., Weimar: vDG, 2005.

7. Karin Hellwag-Konkerth: La estatua ecuestre de Felipe IV de Pietro Tacca y la fachada del Alcázar de Madrid, Madrid: Archivo Español de Arte n²50, 1990, pp. 233-241; José Manuel Matilla: El Caballo de Bronce. La estatua de Felipe IV. Arte y técnica al servicio de la Monarquía, Madrid: Real Academia de Bellas Artes de San Fernando, 1997; Dimitrios Zikas: "Ars sine scientia nihil est». Il contribuito di Pietro Tacca al bronzo italiano (cap.), en op. cit, Falletti, pp. 54-73. Diane H. Bodart: Pouvoirs du portrait sous les Habsbourg d'Espagne, París: CTHS/ INHA, 2011, pp. 414-418.

8. Para un vistazo a los géneros en relación con las influencias en los medios, v.: op. cit., LIEDTKE; Lars Olof Larson: Antonio Tempesta und das Reiterporträt im 17. Jahrhundert eine typologische Studie. In Wege nach Süden. Wege nach Norden. Aufsätze zu Kunst und Architektur. Als Festgabe zum 60. Geburtstag hg.von Adrian von Buttlar, Ulrich Kuder und Hans-Dieter Nägelke, Kiel: Ludwig, 1998, pp. 26-35; Víctor Mínguez, Inmaculada Rodríguez Moya: Napoleón y el espejo de la antigüedad. Arqueología de las imágenes del poder, Valencia: Universidad de Valencia, 2014, pp. 71-88 («Imperator ecuestre»).

9. Acerca del retrato ecuestre español, Walter A. Liedtke, John F. Moffitt: «Velázquez, Olivares,

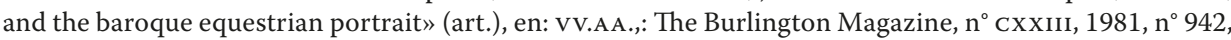
pp. 528-537; John F. MoffitT: «Velázquez y el significado del retrato ecuestre barocco» (art.), en vV. AA: Goya, n 202, 1988, pp. 207-215; Miguel Morán Turina, Fernando Checa, Jonathan Brown: El Palacio del Buen Retiro y el nuevo Museo del Prado Madrid, 2000, pp. 63-87; Víctor Mínguez: La invención de Carlos II. Apoteósis simbólica de la Casa de Austria, Madrid: CEEH, 2013, 193-216 («El rey cabalga y gobierna»). 
ideología que hay detrás de ellos. ${ }^{10}$ Un condicionante de ambos géneros es el interés hipológico, característico del linaje espanol y austríaco, y el entusiasmo por la Escuela Española de Equitación. ${ }^{11}$ Esto ya quedó de manifiesto en 1581 en el primer ilustrado Catálogo de Colección de los Habsburgo: Juan de Austria, el hijo ilegítimo de Carlos V, hizo que Jan van der Straet grabara a cobre una serie de grabados de sus caballos más valiosos. ${ }^{12} \mathrm{Y}$ los retratos de Velázquez y Alonso Cano muestran explícitamente a Felipe IV, y sobre todo a su hijo Baltasar Carlos, en la Escuela de Equitación haciendo la llamada corveta o levade, una maniobra particularmente difícil en el arte de la equitación, ya que el caballo en alza solo puede ser domado con una mano. ${ }^{13}$ Así se utilizaba, entre otras cosas, aquella antigua metáfora de que «un buen gobernante sabe dirigir bien tanto a su caballo como a su pueblo», formulada en 1623 por el jurista Jerónimo de Cevallos en su tratado Arte real para el buen govierno de los reyes y príncipes y de sus vasallos, expressis verbis, con referencia a Valerius Maximus: «El reynar, señor, es como domar un cavallo desbocado, y feroz' que sino se rige con prudencia, y arte, derribarà al que subiere en el. Qui regnum adipiscitur simile est ei, qui equm habet indomitum, à quo nisi cum arte et perittà noverit, tergo eius insidere (Val. Max. lib. 7)». ${ }^{14}$

10. Para un pequeño vistazo de las estautas ecuestres y de las estatuillas de corte en Madrid, Viena y París, Jesús SÁenz de Miera: «Sobre los géneros artísticos y la representación del poder» (art.), en Fernando Checa Cremades (ed.): Cortes del Barroco. De Bernini y Velázquez a Luca Giordano, Madrid: SEACEX, 2003, pp. 216-223 (cat. exp.). Un primer resumen de esta contribución está en: Friedrich Polleroß: "Theatro della Gloria Austriaca”. Das Reiterporträt als Herrschaftszeichen der Casa de Austria» (art.), en Alexandra Merle, Éric Leroy du Cardonnoy (eds.): Les Habsbourg en Europe. Circulations, échanges, regards croisés, pp. 79-92, Figs. 1-29.

11. Elisabeth Gürtler, Armin Basche, René van Bakel: 450 Jahre Spanische Hofreitschule: 450 Years Spanish Riding School. Baden: Edition Lammerhuber 2015; Rubens, Velázquez, and the Spanish Riding School (cap.), en op. cit., LIEDTKE, pp. 18-35.

12. op. cit., Liedtke, pp. 192-193; Marjolein Leesberg, Huigen Leeflang: Johannes Stradanus. Part III (The New Hollstein. Dutch E Flemish etchings, engravings and woodcuts 1450-1750), Amsterdam: Sound \& Vision, 2008, pp. 232-277, NC 527-566. Ya se han tratado las posibles influencias de Velázquez y estos grabados en SABINA De CAVi: «Nuove fonti per l'iconografia equestre del Salón de los Reinos di Velázquez al Buen Retiro (1628-1634/35)» (art.), en Locvs amoenvs, n 11, 2011/2012, pp. 129-149, esp. 136-137.

13. Martin Warnke: Das Reiterbildnis des Baltasar Carlos von Velázquez (cap.), en Kurt Badt, Martin Gosebruch (eds.): Amici amico, Múnich: Fink, 1968, pp. 217-227; Dawson W. Carr: Painting and Reality: The Art and Life of Velázquez (art.) en: Dawson W. CARr, Xavier Bray, John H. Elliot, Larry Keith, Javier Portús: Velázquez, London: Yale University Press 2006, pp. 26-53, 38, esp. 76-179, NC 25, 182-185, 27 (cat. exp.).

14. Jerónimo de Cevallos: Arte real para del buen govierno de los Reyes, y Principes, y de sus vasallos. Toledo: Imprenta de Jerónimo de Cevallos, 1623, fol. 96r. 


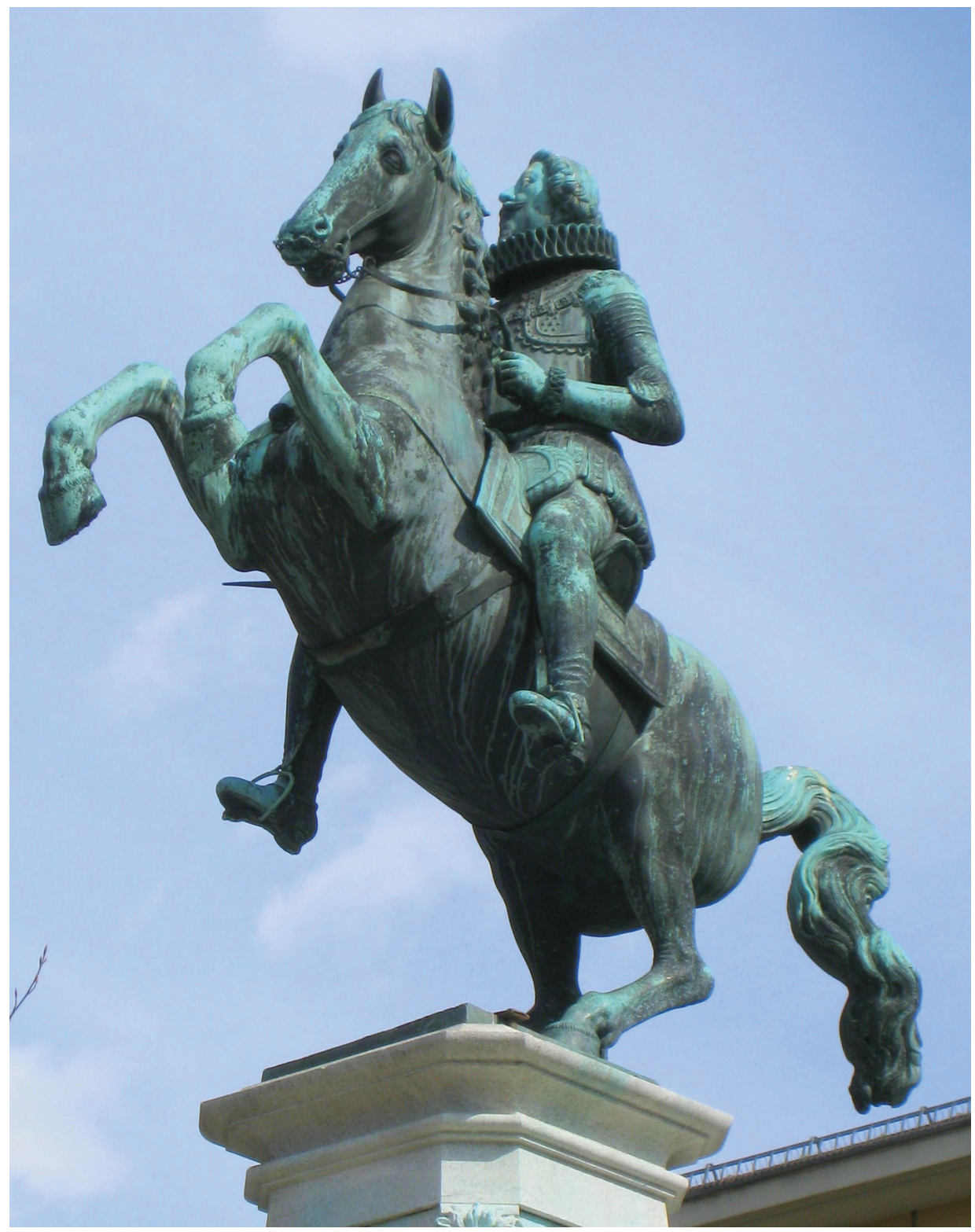

Fig. 2. Estatua ecuestre del Archiduque Leopoldo, Caspar Gras, circa 1625, Innsbruck, Lepoldsbrunnnen 


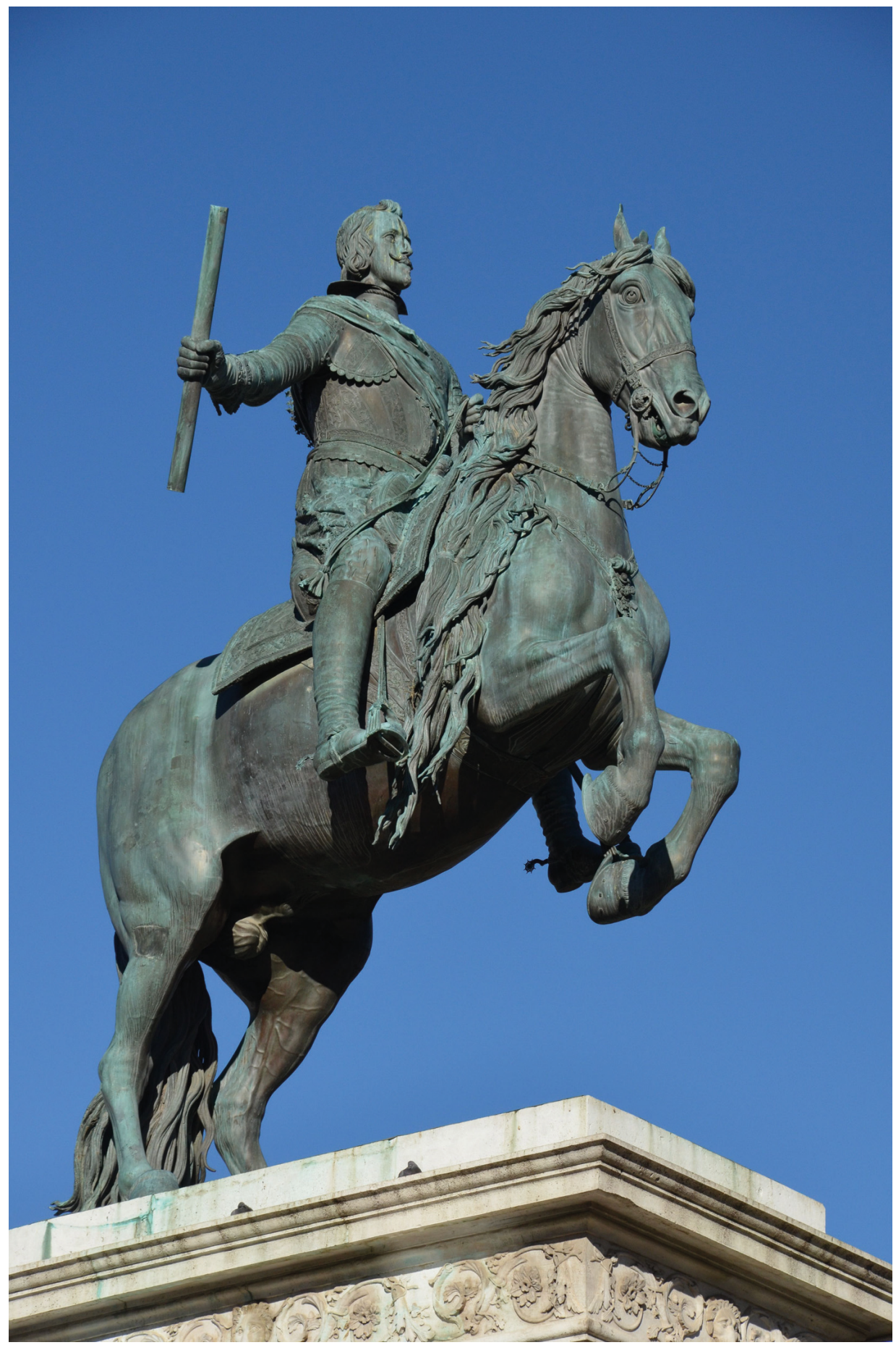

Fig. 3. Estatua ecuestre del rey Felipe IV, Pietro Tacca, circa 1635; Madrid, Plaza de Oriente 
El cuadro de Tiziano del emperador Carlos V en la batalla de Mühlberg en 1548 es un buen punto de partida en un sentido artístico e ideológico (Fig. 4).$^{15}$ Incluso si permite una variedad de interpretaciones iconográficas desde Miles Christi hasta la Profectio Augusti, y desde César hasta Constantino o quizás, mejor dicho, si se relaciona intencionadamente, ${ }^{16}$ el typus se mantiene en la tradición del monumento ecuestre de Marco Aurelio en el Capitolio, que durante mucho tiempo ha sido considerado un monumento del que fuera el primer emperador cristiano Constantino. La pintura sirvió como recordatorio de la victoria imperial sobre la Liga Protestante de Schmalkalden. En consecuencia, el gobernante aparece no solo con la armadura que usó durante la batalla del 24 de abril de $1547,{ }^{17}$ sino también con la banda carmesí de los católicos. En la opinión de Pietro Aretino, el papel de Carlos V como defensor de la fe católica debería haberse visualizado con mayor claridad. El poeta propuso pintar sobre el gobernante las personificaciones de la Religión con un cáliz y una cruz, y de la Fama con una trompeta y un globo terráqueo: «la Religión y la Fama, una con la cruz y el cáliz en mano, que le muestra el cielo, y la otra con las alas y la trompeta, que le ofrece el mundo». ${ }^{18}$

Que el typus encarnaba tanto una imagen española como una imperial en el contexto de los Habsburgo, puede ser probado por algunos grabados. Cuando el veneciano Domenico de Franceschi creó una vera efigie para el príncipe heredero Felipe II hacia 1555, el filio di Carlo Quinto Imperatore no solo fue retratado a caballo, sino también con el águila bicéfala como signo de la descendencia imperial. ${ }^{19}$

15. Fernando Checa: Tiziano y la monarquia hispanica. Usos y funciones de la pintura veneciana en España (siglos XVI y XVII), Madrid: Nerea ,1994, pp. 35-51; La Restauración de El emperador Carlos Va caballo en Mühlberg de Tiziano, cat. exp. Madrid: Museo del Prado 2001; op. cit., BodART, pp. 255-260.

16. Jörg Oberhaidacher: Zu Tizians Reiterbildnis Karls V. Eine Untersuchung seiner Beziehungen zum Georgs-thema (cap.), en Jahrbuch der kunsthistorischen Sammlungen in Wien, $\mathrm{n}^{\circ}$ 78, 1982, pp. 69-90; John F. Moffit T: The Forgotten Role of a „Determined Christian Knight" in Titian's Depiction of,Charles V, Equestrian, at Mühlberg' (art.), en Gazette des Beaux Arts, n 137, 2001, pp. 37-52.

17. Álvaro Soler del Campo (ed.): El arte del poder. La Real Armería y el retrato del corte, Madrid: SEACEX, 2010, pp. 138-141, NC 15, 16 (cat. exp.).

18. Texto original en italiano: «la Religione e la Fama, l'uno con la croce e il calice in mano, che gli mostrasse il cielo, e l'altra con le ali e le trombe, che gli offerisse il mondo» (N. del T.). Carta, ${ }^{\circ}$ CDXII de abril de 1548, en Fidenzio Fertile (ed.): Lettere sull'arte di Pietro Aretino, (1543-1555), Milán: Edizioni del Milione, 1957, p. 212 ( $2^{\circ}$ vol.); Harold E. Wethey: The Paintings of Titian. II. The Portraits, Londres: Phaidon, 1971, pp. 87-90, n² 21; op. cit., CHeCA, p. 42.

19. op. cit., Polleroß, Tabla Xiv. 


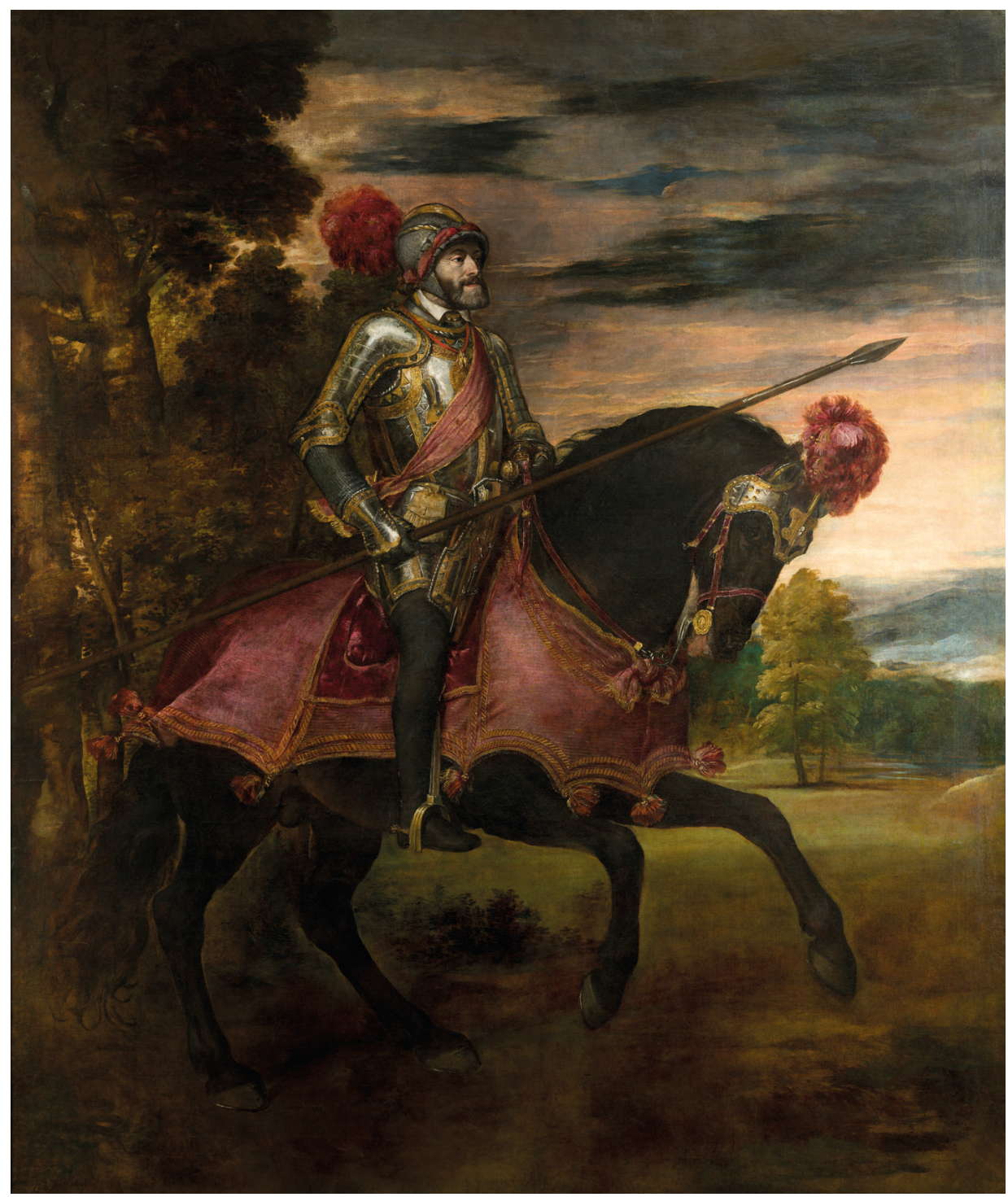

Fig. 4. Carlos V en la Batalla de Mühlberg, Tiziano, 1548, óleo s. lienzo, Madrid, Museo Nacional del Prado

En 1604, en la ciudad imperial de Colonia, se puso en boga la idea de que «a la forma le sigue la función» ["form follows function"], y el grabadista neerlandés Crijspin De Passe la tomó para su serie de retratos a cobre de los Romani Imperatores Domo Austriae editi X hoc tempore postremi. Esta era la contrapieza o la continuación de su otra serie de grabados a cobre de los Doce Emperadores Romanos que hiciera unos años atrás. En su serie de 
retratos de los emperadores habsburgo, también había hecho una referencia iconográfica a los comienzos del antiguo imperio romano, pues a los diez emperadores no solo se les había representado como jinetes, sino además all'antica, con coronas de laurel, armaduras o edificios antiguos romanos al fondo. De estos, el retrato de Alberto I de Habsburgo es una variante de un grabado anterior de Vespasiano, y el de Alberto II, una paráfrasis del de Tiberio en la serie grabada de retratos de los emperadores romanos de Antonio Tempesta..$^{20}$ El título de la obra copia al del frontispicio de Hendrik Goltzius de 1586, que asimismo estaba dedicado a Rodolfo II y reemplazaba la personificación de Roma por el águila bicéfala. ${ }^{21}$ De hecho, desde 1594, De Passe había grabado retratos de Rodolfo II varias veces y también copiado el conocido retrato ecuestre de la serie imperial de Egidio Sadeler según Adriaen De Vries. ${ }^{22}$ Tanto las numerosas alegorías relievadas en bronce de este último y una pintura de Bartholomeus Spranger y Hans von Aachen, ${ }^{23}$ el retrato ecuestre del emperador realizado por el grabadista de Rodolfo II a gran formato, pretendía aludir a las victorias de aquel sobre los turcos a través de una inusual lanza, que toma como referencia directa del retrato ecuestre de Carlos I (Fig. 5). ${ }^{24}$ Este grabado y, sobre todo, el monumento ecuestre a Rodolfo II de $63 \mathrm{~cm}$. de altura de Giambologia (1595 circa), ${ }^{25}$ demuestra que los Habsburgo recurrían a esta iconografía como signo de su dignidad imperial, plasmándola artísticamente a través del característico arte del grabado y las piezas de cámara de arte. ${ }^{26}$

20. Eckhard Leuschner: Antonio Tempesta (= The illustrated Bartsch 35/2), Nueva York, NY: Abaris Books, 2007.

21. K. G. Boon, J. Verbeeck: Van Ostade-De Passe (Hollstein XV), Amsterdam: Hertzberger, 1964, pp. 217-218, NC 655-666; Milan PelC: «Illustrium Imagines. Das Porträtbuch der Renaissance» (art.), en Studies in Medieval and Reformation Thought LXXXVIII, Leiden: Brill, 2002, p. 105, NC 122.

22. Ilija Veldman: «Crispijn de Passe's Representations of Emperor Rudolf II» (art.), en LubomíR Konečný, Lubomir Slaviček (eds.): Libellus Amicorum Beket Bukovinská, Praga: Artefactum, 2013, pp. 136-155, esp. 136-155.

23. Karl VocelKa: «Die politische Propaganda Kaiser Rudolfs II. (1576-1612)», en Veröffentlichungen der Kommission für die Geschichte Österreichs, vol. Ix, Viena: pp. 219-299 („Die Zeit des Langen Türkenkrieges“); Lars Olof Larson: Prag um 1600. Kunst und Kultur am Hofe Kaiser Rudolfs II, Viena: Lucas 1988, pp. 87, 102-104, 163, 182-183, NC 58 (1 $1^{\circ}$ vol), nc 548-550, $6762^{\circ}$ vol.; vV.AA.: Praga magica 1600, Dijon: Dijon, 2002, nC 29 (cat. exp.); Claudia Reichl-Ham: Der „Lange Türkenkrieg“ Rudolfs II. und seine Rezeption im Heeresgeschichtlichen Museum (art.), en Viribus Unitis. Jahresbericht, Viena, 2008, pp.11-34, esp. pp. 7-22.

24. Alena Volrábová, Blanka Kubíková (eds.): Rudolf II. a mistři graficke’ho umĕní, Praga: Národní Galerie v Praze, 2012, pp. 20-21, NC 1/3 (cat. exp.).

25. op. cit., LARSSON, p. 139, NC 46.

26. Eckhard Leuschner: «Roman Virtue, Dynastic Succession and the Re-Use of Images: Constructing Authority in Sixteenth \& Seventenneth-Century Portraiture» (art.), en Studia Rudolphina, $\mathrm{n}^{\circ}$ 6, 2006, pp. 5-25, 19-21; Friedrich Polleroß: „Kayserliche Schatz- und Kunstkammer". Die habsburgischen Sammlungen und ihre Öffentlichkeit im 17. Jahrhundert (cap.), en SABINE HA AG, FRANZ Kirchweger, Paulus Rainer (eds.): Das Haus Habsburg und die Welt der fürstlichen Kunstkammern im 16. und 17. Jahrhundert, Viena: Holzhausen, 2016, pp. 255-295, esp. 255-262. 


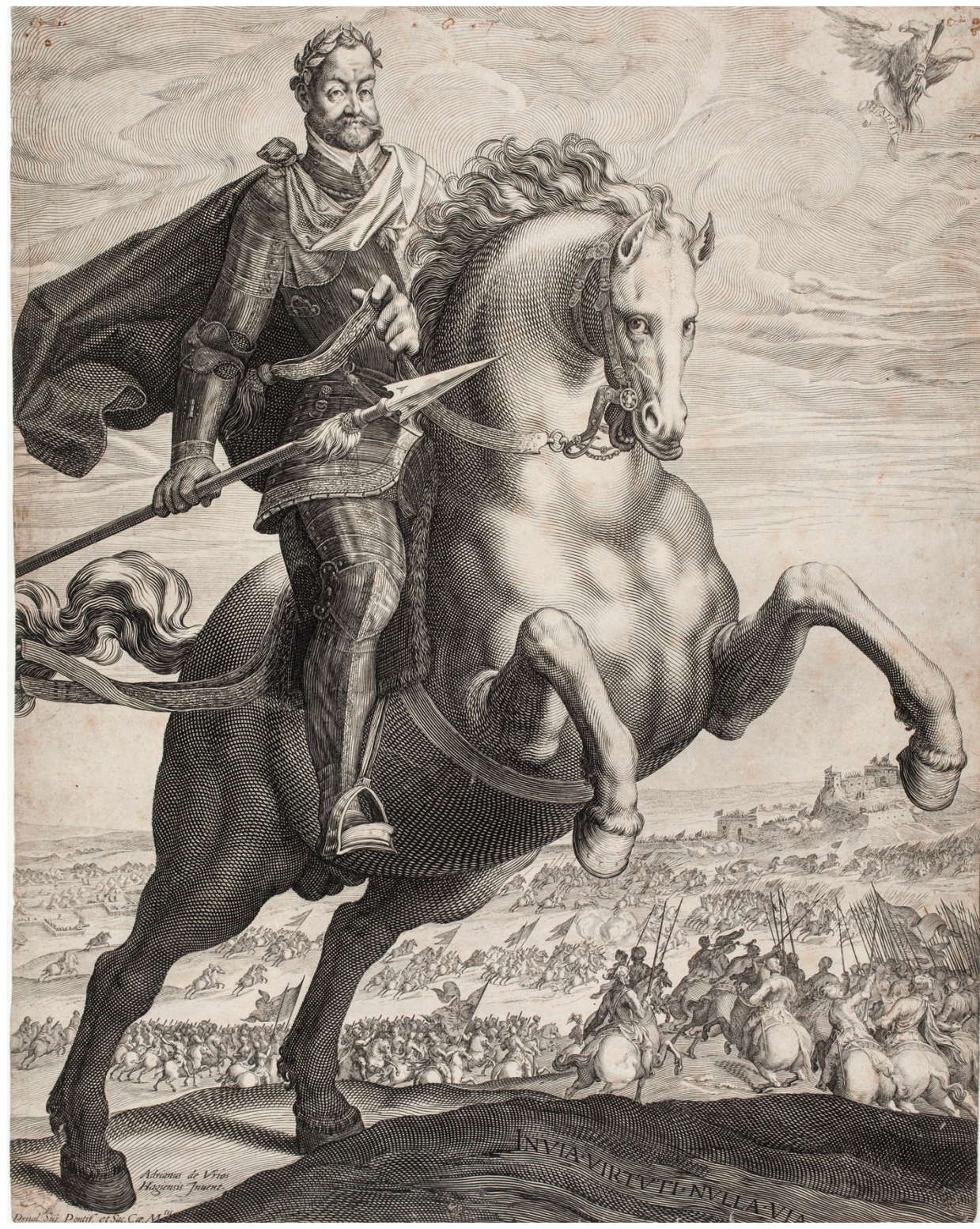

Fig. 5. Retrato ecuestre del emperador Rodolfo II, Edigio Sadeler según Adriaen de Vries, circa 1603/4, Colección Friedrich Polleroß

Empero, el retrato ecuestre (con el caballo sobre dos patas) no solamente alude a una raíz española y romana, sino también, explícitamente, como se ha mencionado anteriormente, a una tradición imperial habsburga, como el monumento al rey Rodolfo I en Estrasburgo, que se describe en el Espéculo 
de Honor de la Casa de Austria de 1555. Rodolfo II y sus herederos disponían de una copia de este manuscrito, por lo que no es seguramente una casualidad que el «tipo rudolfiniano» de retrato ecuestre fuera explícitamente adoptado tanto por el emperador Fernando II como por su hijo. Así produjo Lucas Kilian un grabado en cobre de gran formato del rey romano tras la victoria habsburga contra los protestantes en la Batalla de Nördlingen de 1634, como paráfrasis directa con el retrato de grabado de Rodolfo II (Fig. 6). ${ }^{27}$

No obstante, Fernando III también recurrió a la segunda idea de su predecesor, esto es, a la representación de la majestad imperial por medio de estatuillas ecuestres en la cámara de arte. ${ }^{28}$ Los monumentos del cuarto imperial de Rodolfo II, del archiduque Maximiliano III y del archiduque Leopoldo V eran todavía las piezas únicas ${ }^{29}$ que había, por lo que, poco después de asumir el cargo de emperador, se hizo cargo del rediseño de estas, mandando hacer una serie de monumentos representativos que revalorizara el concepto rudolfiniano de crear una cámara de arte imperial. ${ }^{30}$ Alrededor de 1640 , se le encargó a Caspar Gras la realización de estatuillas ecuestres en metal de Fernando II y Fernando III, seguidas de las de Segismundo Francisco y Leopoldo I. ${ }^{31}$ Así, el principio de representación de la secuencia de retratos ecuestres de series imperiales de entre $1580^{32}$ y 1640 se trasladaba deliberadamente al género de los monumentos de cámara de arte (Fig. 7). Sin embargo, al no solo porque era de la familia, sino además por la conexión artística y política con su primo, cuñado y suegro Felipe IV, ${ }^{33}$ la idea de Fernando III de crear una serie familiar vienesa de retratos ecuestres, o podría haber tenido su inspiración en la de Madrid, o al menos haberse desarrollado al tiempo que esta, e incluso junto con ella. De hecho, se hizo una estatuilla ecuestre en bronce dorado de Felipe IV como príncipe de la corona alrededor de 1615-1620, atribuida a Pietro Tacca. No se conoce quién fue el propietario original de la obra que el Museo del Prado compró en 1952, como tampoco de qué se

27. Gerd Dethlefs: Das Kunstwerk des Monats, Münster: wflm Münster, 2016: http://www.lwl. org/landesmuseum-download/kdm/archiv/2016/Ans_KdM_Mai_2016.pdf.

28. Sobre el efecto modelo a seguir de las impresiones, etc. en los retratos ecuestres de Velázquez v, op. cit. LARSSON, pp. 26-31.

29. Para la estatuilla ecuestre del archiduque Maximiliano III, de Hubert Gerhard, de ca 1600/05 v., Gert Ammann (ed.): Ruhm und Sinnlichkeit. Ruhm und Sinnlichkeit. Innsbrucker Bronzeguss 1500-1650 von Kaiser Maximilian I. bis Erzherzog Ferdinand Karl, Innsbruck: Tiroler Landesmuseum, 1996, pp. 242-244 (exp. cat.). (Manfred Leithe-Jasper).

30. Evidentemente, se completaron los bustos de Carlos V de Leone Leoni y Rodolfo II de Adriaen de Vries a partir del busto de bronce de Fernando III von Schweiger: op. cit., Polleroß, p. 268.

31. op. cit., AmManN, pp. 300-317.

32. Gabriele Vitásek: Das Effigerivm caesarvm opvs, Kaiserreihe von 1580, Viena: FrühneuzeitInfo, $\mathrm{n}^{\circ} 11,2000$, cuaderno 2, pp. 28-49.

33. Friedrich Polleroß: «Serie, Paraphrase, Kopie: Diego Velázquez und Frans Luycx als Porträtisten der Casa de Austria»(art.), en Sylvia Ferino-Pagden (ed.): Velázquez: Anregungen, Vorschläge, Lösungen, Viena: Кнм, 2018, pp. 142-165. 
trataba, de si era un borrador para una segunda estatua en Madrid, o si era «solo» un regalo diplomático y obra de cámara de arte. ${ }^{34}$

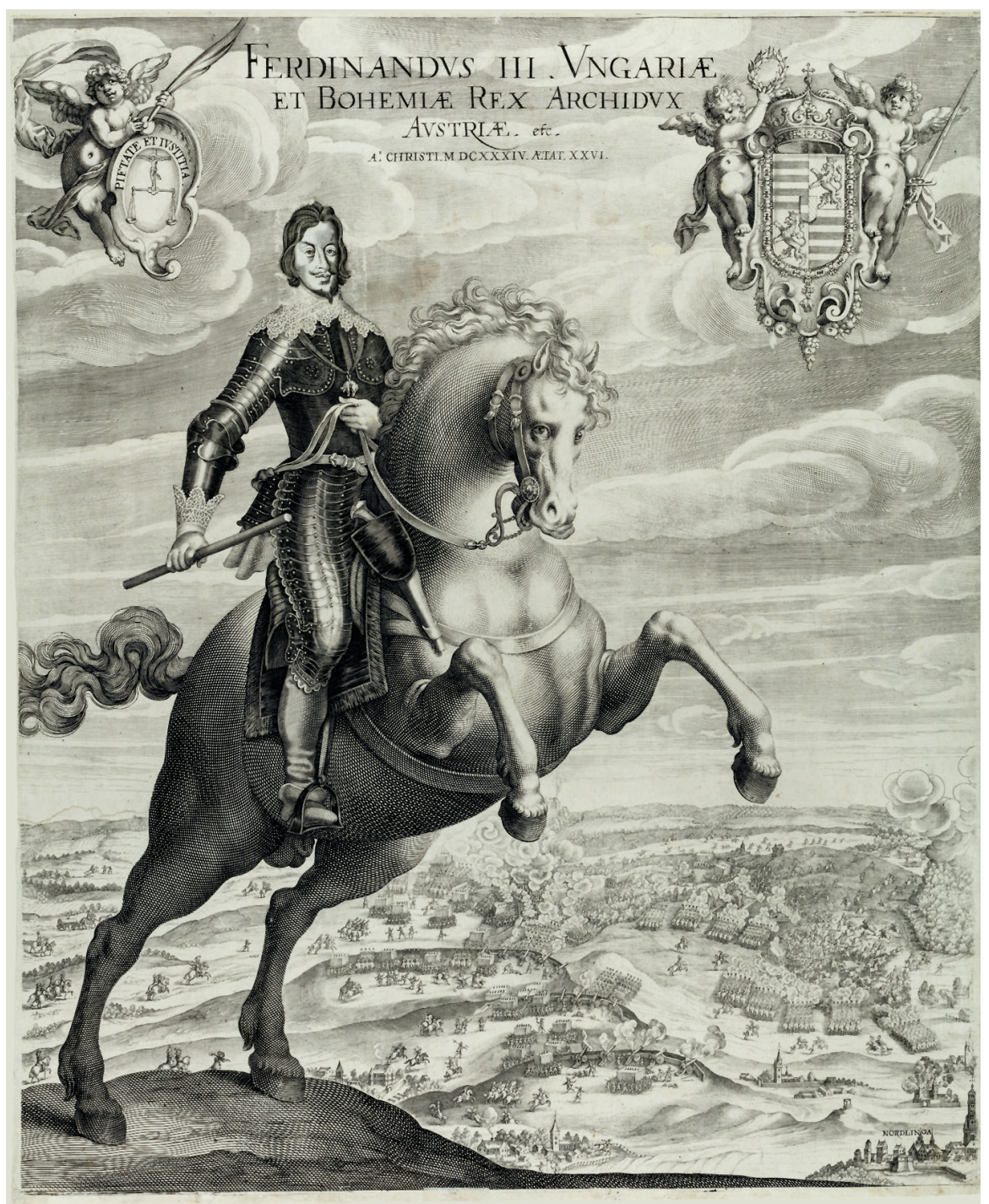

Fig. 6. El rey Fernando III de Hungría como vencedor de la Batalla de Nörlingen, Lucas Kilian, 1634, grabado en cobre, Colección Friedrich Polleroß

34. Leticia Azcue Brea: «Panorama de la escultura cortesana y el coleccionismo escultórico nobiliario en la época de Felipe IV. Estado de la cuestión» (art.), en José MARTínez Millán, MANUEL Rivero Rodríguez (ed.): Arte, coleccionismo y sitios reales (La corte de Felipe IV (1621-1665): Reconfiguración de la Monarquía católica III/4), Madrid: Polifemo, 2017, pp. 2.871-3.001 (esp. 2.9672.971), Fig. 10. 


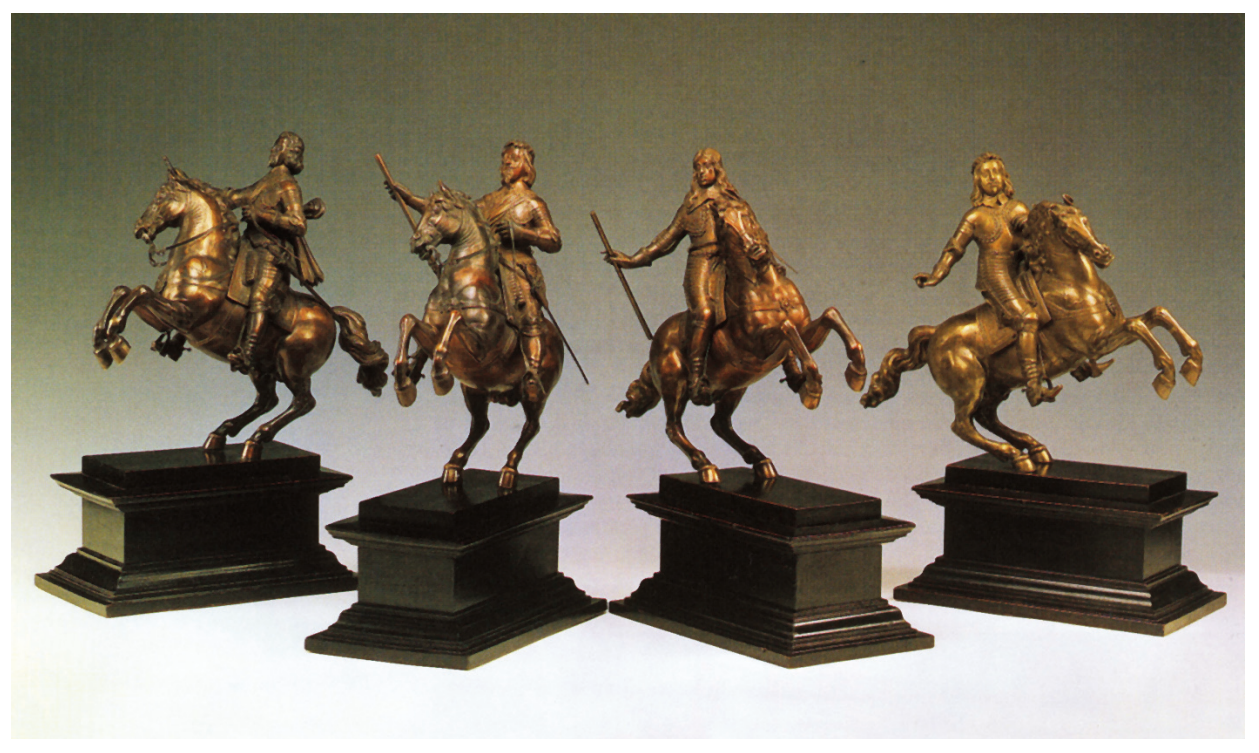

Fig. 7. Estatuillas ecuestres de los emperadores Fernando II y Fernando III y los archiduques Sigmund Franz y Fernando Carlos, Caspar Gras, circa 1640 y circa 1650 resp., Viena, Kunsthistorisches Museum, Kunstkammer

Aparte de esto, tras su remodelación, el Salón Nuevo del Alcázar de Madrid -que más tarde sería conocido como Salón de los Espejos, siendo el más representativa de la residencia real española- se decoró en torno a 1625 con el retrato ecuestre de Carlos V en la Batalla de Mühlberg, la alegoría Felipe II ofreciendo al cielo al infante Don Fernando tras la Batalla de Lepanto, y la alegoría de la Contrarreforma La Religión socorrida por España, de Tiziano ${ }^{35}$. También estaba el retrato ecuestre de Felipe IV y la pintura de Felipe III y la Expulsión de los Moriscos, de Velázquez ${ }^{36}$. Al rey español no solo se le retrató con el prognatismo heredado de su bisabuelo sino, además -como se dice en una carta del nuncio papal fechada del 16 junio de 1625- "como un César» ${ }^{37}$. Desafortunadamente, no sabemos si esta declaración de la carta dirigida al Vaticano se refería a una a comparación con Carlos V, al caballo sobre dos patas, o a la armadura all'antica.

35. Sobre las pinturas de Tiziano, v. op. cit., CHECA, pp. 36-87.

36. Steven N. Orso: Philip IV and the Decoration of the Alcázar of Madrid, Princeton: Princeton University Press 1986, pp. 43-60; Fernando CheCA (ed.): El Real Alcázar de Madrid. Dos siglos de arquitectura y coleccionismo en la corte de los Reyes de España, Madrid: Nerea, 1994, p. 391 (cat. exp.).

37. Jeannine Baticle: «El retrato ecuestre del rey Felipe IV» (art.), en Svetlana Alpers et al.: Velázquez, Barcelona: Galaxia Gutenberg, 1999, pp. 57-69 (esp. 62). 


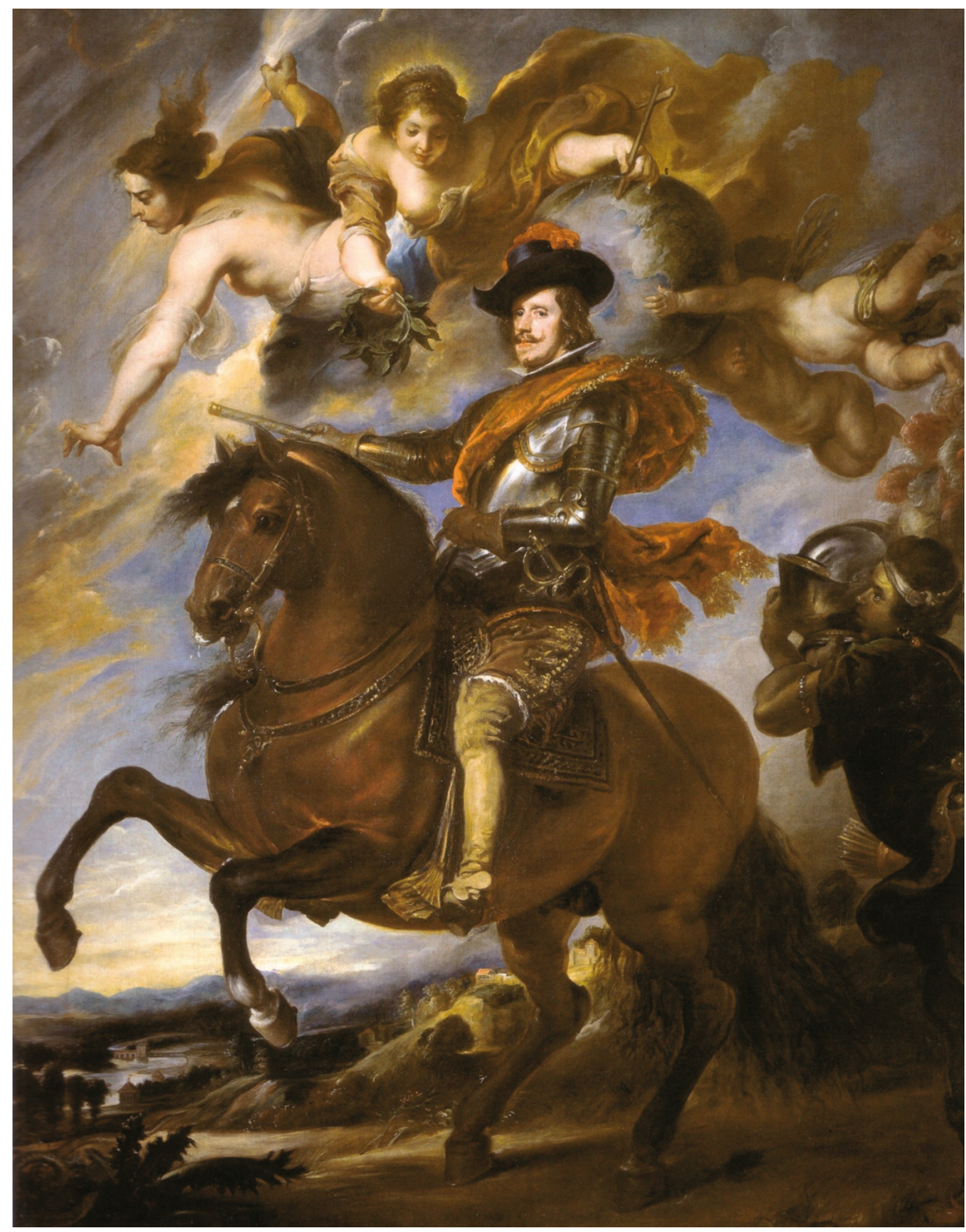

Fig. 8. Retrato del rey Felipe IV, Diego de Velázquez y taller según Peter Paul Rubens, circa 1645, óleo sobre lienzo, Florencia, Galleria degli Uffizi

El retrato del [entonces] monarca gobernante se reemplazó, sin embargo, por el retrato ecuestre de Felipe IV como defensor global de la Fe Católica de Peter Paul Rubens, donde se representa la personificación de la Justicia 
Divina y el Furor Divino, la Fe y la Herejía, que se simboliza con la serpiente y la representación del globo (introduciéndose la alegoría barroca en el retrato del rey español). La obra solo nos ha llegado como copia (Fig 8) ${ }^{38}$. Intencionadamente o no, se fiió en la iconografía de Aretino para este retrato de Carlos V. ${ }^{39}$ Y fue probablemente el maestro flamenco quien pintara en 1625 con la Galería Medici de París un «incunable» barroco de una obra política de arte total [Gesamtkunswerk], ${ }^{40}$ además de la serie de tapices El Triunfo de la Eucaristía (una glorificación del emperador Fernando II y del rey Felipe IV como defensores de la Fe Católica en la Guerra de los Treinta Años). ${ }^{41}$ Quizá Rubens tenía ya de antes esta idea en mente tras su regreso a Amberes, a saber, no solo intercambiar el retrato de Felipe IV, sino además colgar su copia del retrato de Felipe II sobre la Batalla de San Quintín (tomando como modelo el de Carlos V en el Tapiz de Túnez de Jan Cornelis Vermeyen), ${ }^{42}$ en lugar de la «ofrenda real» de Tiziano, y otro retrato ecuestre del Infante Cardenal Fernando de Austria como vencedor de los protestantes; ${ }^{43}$ organi-

38. Frances Huemer: Portraits I. Corpus Rubenianum Ludwig Burchard XIX, Bruselas: Arcade, 1977, pp. 150-154, NC 30; LARry L. Ligo: «Two Seventeenth-century Poems which link Rubens Equestrian Portrait of Philip IV to Titian's Equestrian Portrait of Charles V» (art.), en Gazette des BeauxArts, $\mathrm{n}^{\circ} 112$, 1970, pp. 345-354; MARY CRAWFORD VOLK: «Rubens in Madrid and the decoration of the Salón Nuevo in the Palace» (art.), en The Burlington Magazine, n CxxiI, 1980, n 924, pp. 168-180; Alejandro Vergara: Rubens and his Spanish Patrons, New York, Cambridge University Press, 1999, pp. 67-75; Garín Llombart, Salvador Salort Pons: Velázquez, Milán: Electa, 2010, pp. 232-237; José López-Rey, Odile Delenda: Velázquez. Das vollständige Werk, Colonia: Taschen, 2014, p. 374, nC 96; Sabine HaAg (ed.): Velázquez, Múnich: Hirmer, 2014, NC 24 (Javier Portús Pérez) (cat. exp.), Dominique Jacquot: Rubens. Portraits princiers, París: Réunion des Musées Nationaux, 2017, pp. 126127, NC 21 (cat. exp.).

39. En 2001 expresó Falomir una opinión similar: Miguel Falomir Faus: «Tiziano, el Aretino y las "alas de la hipérbole". Adulación y alegoría en el retrato de los siglos XVI y XVII» (art.), en VV. AA., La Restauración de «El emperador Carlos V a caballo en Mühlberg» de Tiziano, Madrid: MNP, 2001, pp. 71-86, (esp. 74-80).

40. Bernhard Wehlen: „Antrieb und Entschluss zu dem was geschieht". Studien zur Medici-Galerie von Peter Paul Rubens, Múnich: Scanneg, 2008; Nico VAn Hout: "Henry IV valait bien une Galerie!" Rubens unvollendetes Projekt für das Palais du Luxembourg (cap.), en Gerhard FincKH, NicOLE Hartje-Grave (eds.): Peter Paul Rubens, Wuppertal: Van der Heydt-Museum, 2012, pp. 88-115; Olaf MüCKain: Zwei Gemäldezyklen für den französischen Hof (cap.), en op. cit., Finckн, Hartje-Grave, pp. 268-293. Ulrich Pfisterer ha sido el primero en señalar las posibles relaciones entre la galería de Rubens en París y sus pinturas en Madrid, v. Ulrich Pfisterer: Malerei als Herrschafts-Metapher. Velázquez und das Bildprogramm des Salón de Reinos (cap.), en Marburger Jahrbuch für Kunstwissenschaft, $\mathrm{n}^{\circ} 29$, 2002, pp. 199-252 (esp. 210-211).

41. Wolfgang Brassat: «Für die Einheit der katholischen Liga. Zum politischen Gehalt des Eucharistie-Zyklus von Peter Paul Rubens. Idea» (art.), en Jahrbuch der Hamburger Kunsthalle, ${ }^{\circ}$ VII, 1988, pp. 43-62; Marion Lisken-Pruss: Rubens im Dienst des Brüsseler Hofes (cap.), en op. cit., FincK, Hartje-Grave, pp. 176-203; Anne Woollet t: Faith and Glory. The Infanta Isabel Clara Eugenia and the ,Triumph of the Eucharist' (cap.), en Alejandro Vergara, Anne Wollett (eds.): Spectacular Rubens. The Triumph of the Eucharist, Los Angeles: J. Paul Getty Museum, 2014, pp. 10-29.

42. El cuadro, que no apareció en el inventario del Alcázar hasta 1686, entre 1629 y 1640, v. op cit., Falomir, p. 74, 84; op. cit., CheCA, de Urríes y del Colina, pp. 212-216, NC 54; op. cit., Bodart, pp. 260-263.

43. op. cit., BROWN, pp. 136-139, NC 8. 
zando los motivos de las cuatro esquinas de la sala, como si fuera una galería, para así continuar la serie, sino ideológica, al menos iconográficamente. ${ }^{44}$

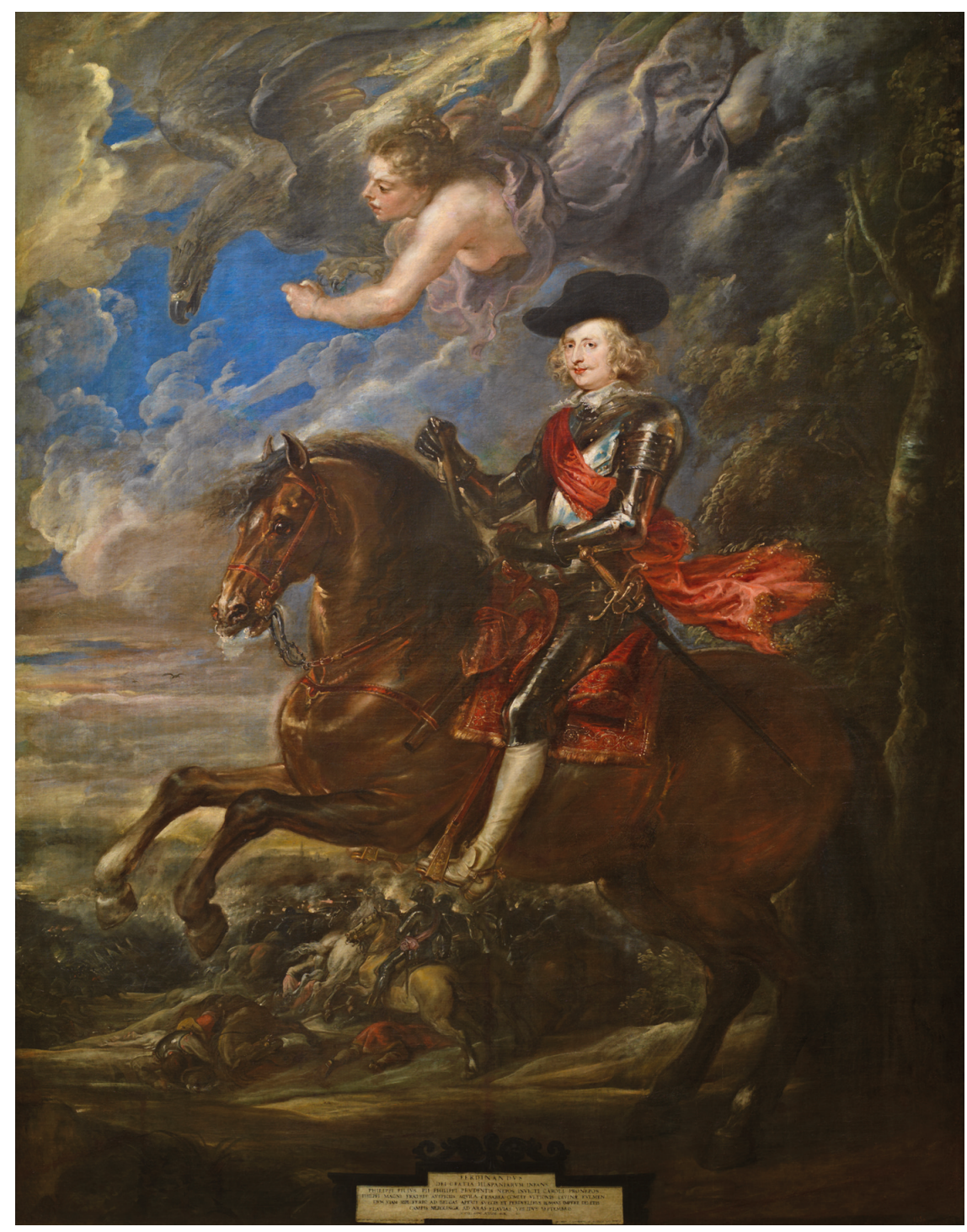

Fig. 9. Retrato ecuestre del cardinal-infante Fernando, Peter Paul Rubens, circa 1635, óleo sobre lienzo, Madrid, Museo Nacional del Prado

44. También aquí Falomir expresó una opinión similar, v.op.cit., FAlOMIR, pp. 83-86; vgr., AlEJANDRO Vergara: El universo cortesano de Rubens (cap.), en op. cit., Brown, pp. 67-89 (esp. 83-85); UlRICH Heinen: Loyalität-Diplomatie-Religion. Peter Paul Rubens' Beitrag zum Überleben der Habsburgischen Niederlande (cap.), en Gerhard Finckh, Nicole Hartje-Grave: Freiheit-Macht-Pracht, Wuppertal: Heydt-Museum, 2009, pp. 10-31 (cat. exp.). 


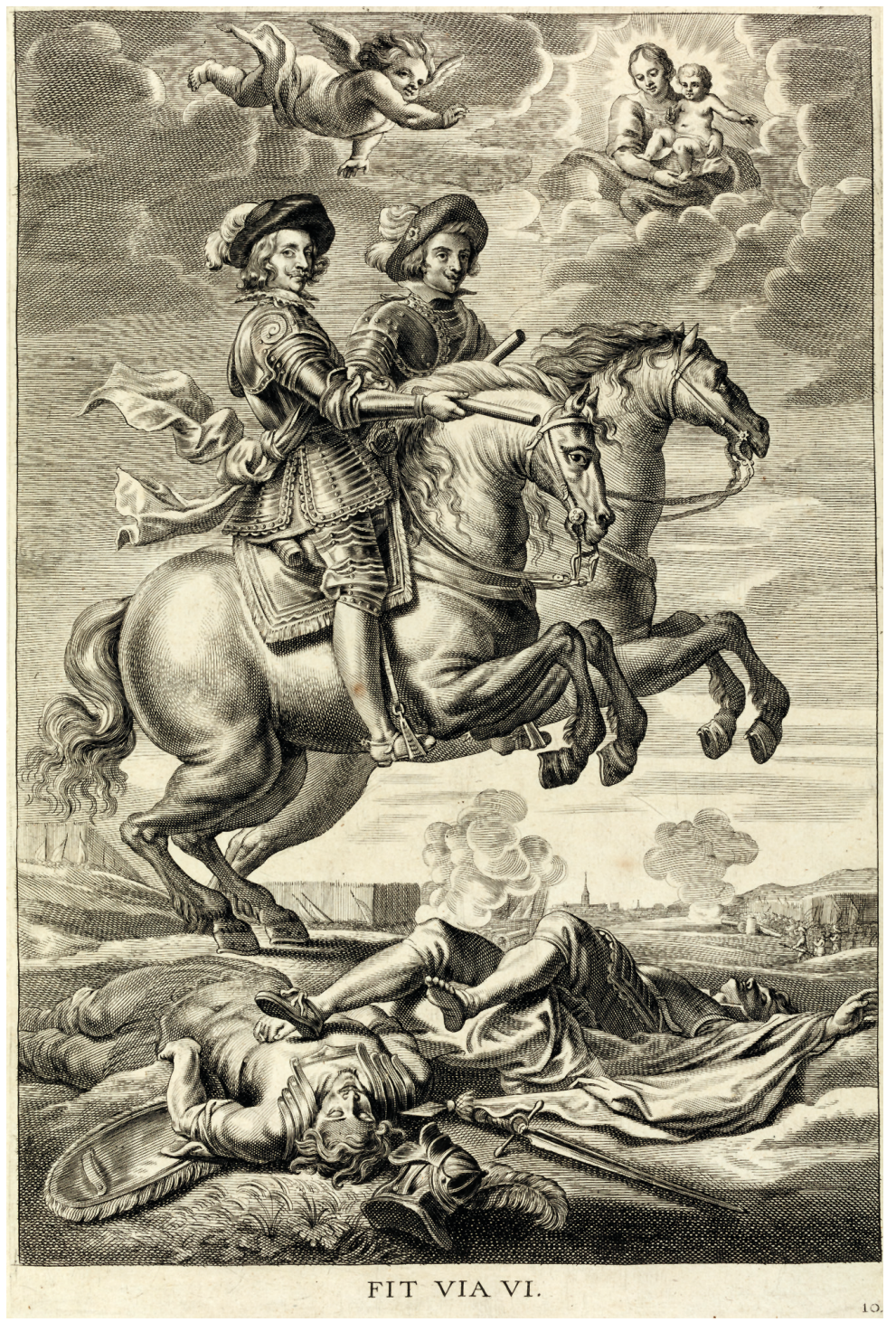

Fig. 10. Rey Fernando III de Hungría y cardinal-infante Fernando en una Visión de la Virgen en la Batalla de Nördlingen, Peter de Jode según Cornelis Schut), 1636, reproducción del óleo sobre lienzo para un arco triunfal, Colección Friedrich Polleroß

En una pintura amberina de las festividades de Gante en conmemoración del triunfo de $1634,{ }^{45}$ retrataron Cornelis Schut y su maestro Rubens al Fernando

45. John R. Martin: The Decoration of the Pompa Introitus Ferdinandi, Bruselas: Arcade, 1972, pp. 147-150, NC 37. 
español y al austríaco, juntos a caballo como vencedores de la Batalla de Nördlingen (Fig. 10). ${ }^{46}$ La visión de la Madre de Dios junto con el Niño Jesús resulta del hecho de que los Habsburgo ya la habían declarado Generalissima de sus ejércitos. ${ }^{47}$ Lo que testimonia que el retrato ecuestre triunfante [pretendía] mostrar claramente la victoria militar de la Casa de Austria sobre los «incrédulos» protestantes y musulmanes, con la ayuda de Dios. En este contexto, conviene también hacer referencia a las representaciones de Santiago Matamoros sobre un caballo a dos patas, quien en el siglo XVII se convirtió en «figura simbólica en la lucha contra los herejes y el paganismo».. ${ }^{48}$ Aun cuando la suposición de esta serie rubensiana para el Salón de Espejos fuera especulativa, este concepto subyacente politico-pedagógico también se observa en una pintura de Gaspar de Crayer, alumno de Rubens, que fue realizada en Ginebra para un arco de triunfo en honor al Cardenal Infante Fernando tras la Batalla de Nördlingen de 1634. En esta representación se encuentran el mariscal de campo español y su tatarabuelo a caballo y con la batuta de mariscal en el campo de batalla (Fig. 11) ${ }^{49}$ en una concepción genealógica en la cual Carlos V instruye a su descendiente..$^{50}$ Dice la inscripción del grabado posterior «DISCE NEPOS VIRTVTEM EX ME» («Aprende, nieto, de mí la virtud»). De hecho, la idea de que los gobernantes debían aprender de la historia y los modelos a seguir le era familiar a Felipe IV desde su niñez y el Salón de los Espejos era de manera clara no solamente una galería de pinturas, sino también un «Salón de la Virtud Principesca» («a Hall of Princely Virtue") y, más concretamente, un Salón de la Fama de los Reyes Católicos. ${ }^{51}$ En este contexto, me parece probable que los llamados ocho espejos de la sala con sus marcos de bronce dorado y forma de águila no sean decoraciones lujosas, sino que también deban interpretarse simbólicamente como espejos (espéculos) de la virtud y, por lo tanto, son parte esencial de este concepto.

Nos es permitido hacer tal interpretación, sobre todo a raíz de un frontispicio del alumno y nieto de Rubens, Erasmus Quellinus I, publicado en Bruselas

46. Sobre la pintura, v. op. cit., LiedtKe, p. 266, NC 138; Gertrude Wilmers: Schut Cornelis (15971655). A Flemish Painter of the High Baroque, Turnhout: Brepols, 1996, pp. 83-85, NC 22; JAN WALGRAVE: A Royal Image. The Image of the Sovereign since Sir Anthony Van Dyck, Amberes: Amberes, 1999, pp. 131-132, NC 34 (cat. exp.).

47. Anna Coreth: Pietas Austriaca. Österreichische Frömmigkeit im Barock. Viena: Oldenbourg Wissenschaftsver-lag 1982, pp. 45-72.

48. Michael Scholz-Hänsel: Bildpropaganda gegen die Anderen. Spanische Kunst im europäischen Kontext der Toleranzdiskussion des Westfälischen Friedens (cap.), en KLAUS BuSSMANN, Heinz Schilling: Krieg und Frieden in Europa (tomo 2), Osnabrück: 350 Jahre Westfälischer Friede mbH, 1998, pp. 131-139, 133, Fig. 1.

49. Acerca de esta pintura, v. op. cit., Liedtke, p. 268, n 40; Hans Vlieghe: Gaspar de Crayer, sa vie es ses oeuvres, Bruselas: Arcade, 1972, pp. 120-121, Fig. 50; CARL VAN DE Velde, Hans Vlieghe: Stadsversieringen te Gent in 1635 voor de blijde intrede van den Kardinaal-Infant, Gante: Stadt Gent, 1969, pp. 51-53, Il. 39-40.

50. En 1622 se representó este tema en un grabado a cobre de Pedro Perret. En él se muestra al infante Don Carlos ante el retrato de Carlos V, en cuyos marcos aparece escrito «VIRTVTEM EX ME», v. El linaje del emperador, Cáceres: Centro de Exposiciones San Jorge, 2000, pp. 378-379, NC 8.7. (cat. exp.).

51. op. cit., Orso, pp. 89-95 
en 1655 en el Speculum Principium de Petrus Belluga, que muestra a un gobernante (habsburgo) y a la alegoría de la Fe y la Unidad o la Justicia, quienes le sujetan el espejo en el cual aparece rodeado de las personificaciones de la Virtud (Fig. 12)..$^{52}$ El significado central artístico-alegórico que se le asigna al espejo en el retrato de grupo Las Meninas de Velázquez hace tan evidente esta conjetura, ${ }^{53}$ como respecto a los siguientes cuadros del Salón de Reinos. «Un verdadero speculum principium» que también se ha visto en varias representaciones del heredero al trono Carlos II. ${ }^{54}$ La decoración del salón seguía el mismo patrón que el de la galería en honor a Carlos V y que el de Galería de las Doce Virtudes en honor a Felipe III en el Palacio del Pardo..$^{55}$

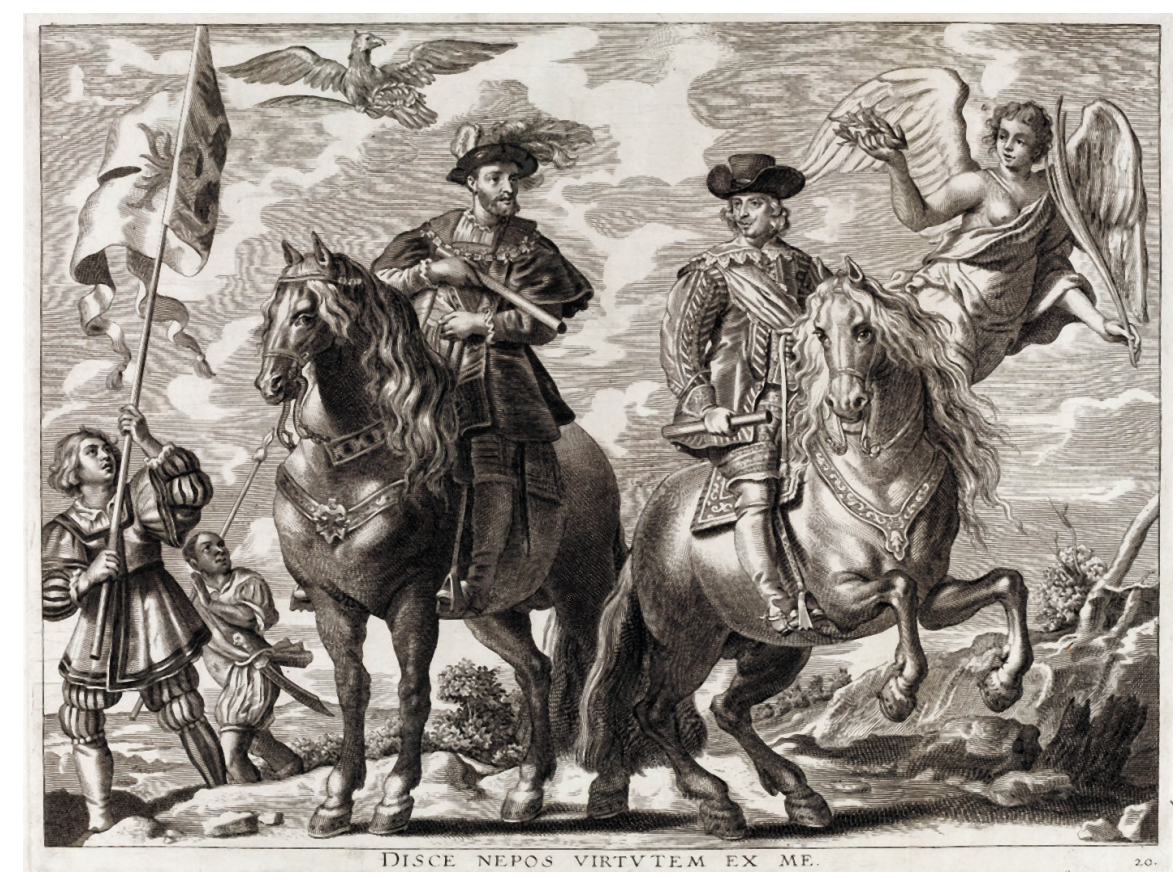

Fig. 11. Carlos V modelo a seguir del cardenal-infante Fernando, Peter de Jode (según Caspar de Crayer), reproducción del óleo sobre lienzo para un arco triunfal, 1636, Colección Friedrich Polleroß

52. Ann Diels: The Shadow of Rubens. Print Publishing in $17^{\text {th }}$ century Antwerp. Prints by the history painters Anselm van Diepenbeeck, Cornelis Schut and Erasmus Quellinus II, Londres: Brepols, 2009, Il. 38. El tema se convirtió más tarde en una alegoría de Leopoldo I.

53. Jan Ameling Emmens: „Las Meninas“ von Velázquez: Fürstenspiegel für Philipp IV (art.), en Thierry Greub (ed.): Las Meninas im Spiegel der Deutungen, Berlín: Dietrich Reimer Verlag, 2001, pp. 115-133; Martina Pippal: „Las Meninas“ von Diego Velázquez-des Rätsels Lösung? (art.), en op. cit., FERINO, pp. 166-195 (esp. 185).

54. op. cit., Mínguez, pp. 65-72.

55. RichaRD L. KAGAN: «Imágenes y política en la corte de Felipe IV de España. Nuevas perspectiva sobre el Salón de Reinos» (art.), en JoAn Lluís Palos, Diana Carrió-Invernizzi (eds.): La historia imaginada, Madrid: CEEH, 2008, pp. 101-119 (esp. 106-107). 


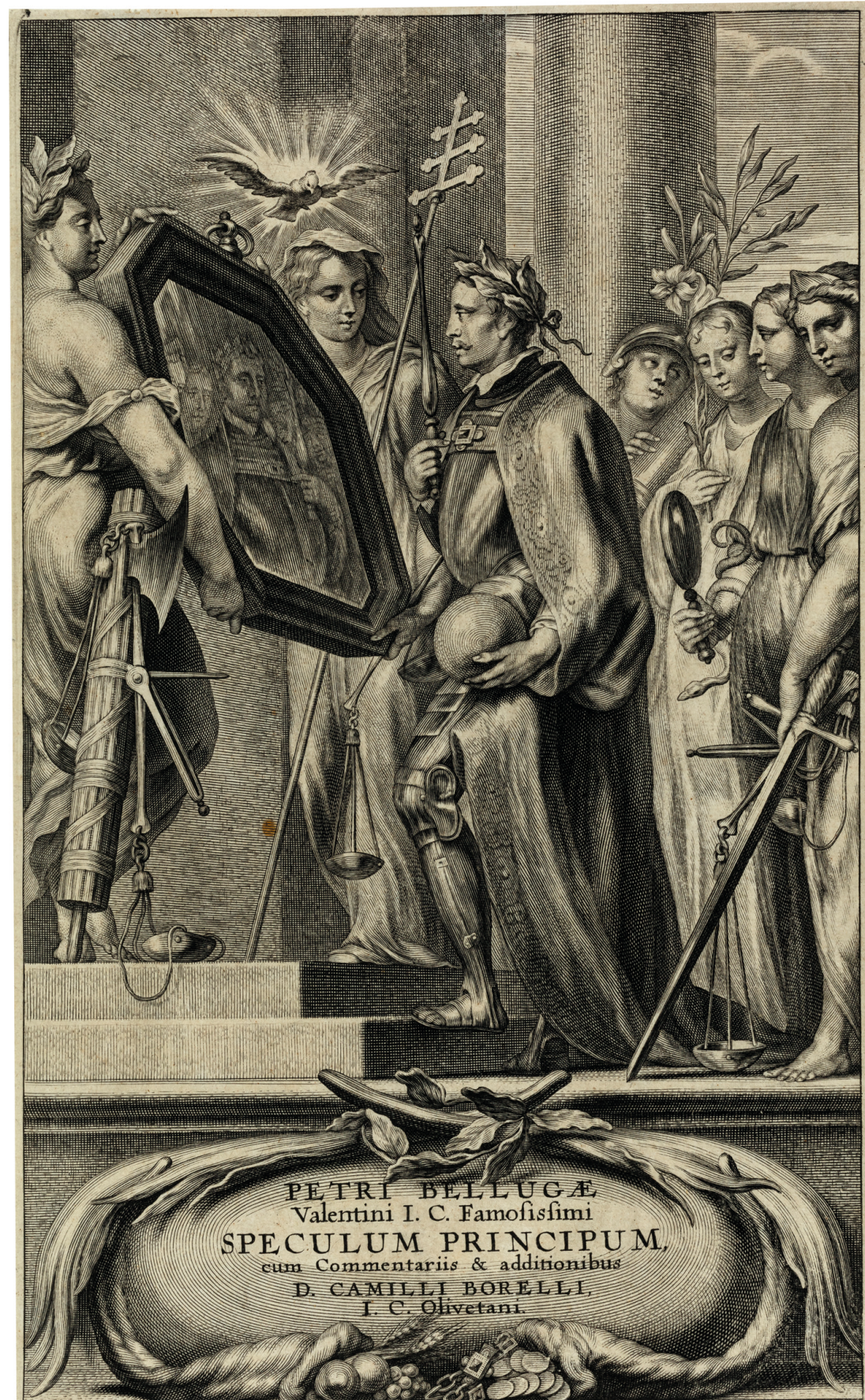

BRU XELLIS ex officina FraNCISCI VIVIEN fub figno beni Paftoris.M. DC.LV.

Fig. 12. Alegría del speculum del príncipe (Frontispicio del Titelkupfer del libro «Speculum Principium» de Pedro Belluga), Erasmus Quellinus, 1665, Colección Friedrich Polleroß 
En cualquier caso, era lógico que precisamente alrededor de 16341635 , el concepto de retrato ecuestre en serie iniciado en el Alcázar de Madrid se retomara y utilizase también para el mobiliario de la Sala del Trono del Palacio del Buen Retiro. Las entonces pinturas de gran formato de Felipe II y María de Austria -inicialmente estaban destinadas a la residencia de la ciudad-fueron hechas más grandes con tiras de lienzo e instaladas en los estrechos muros del Salón de Reinos junto con los retratos de Felipe IV e Isabel de Borbón, también de Velázquez y taller (Fig. 13, Fig. 14). ${ }^{56} \mathrm{Al}$ mismo tiempo, los cuatro retratos ecuestres junto con el retrato ecuestre de menor tamaño del sucesor al trono Baltasar Carlos (Fig. 15), así como con un ciclo de reyes españoles, los escudos de armas de los veinticuatro imperios, una serie de batallas de por aquel entonces, en su mayoría contra los neerlandeses calvinistas, y una serie de obras sobre Hércules, ideológicamente se completaban e integraban ${ }^{57}$ con el fin de -como explicó el poeta cortesano José Pellicer de Tovar en 1635 en un soneto del retrato ecuestre de Baltasar Carlos- «animar al espectador a actos de gloria aún mayores». ${ }^{58}$ Todas esas referencias temáticas apuntan al retrato ecuestre del sucesor del trono en medio de los retratos de sus padres sobre los estrechos muros de la sala, como recogió el poeta portugués Manoel de Galhegos en 1637 en sus poemas laudatorios la Silva topográfica al Buen Retiro ${ }^{59}$ : «Entra en esse Salon; y alegre mira/ la copia de Felipo, que pendiente/ adorna desta puerta lo eminente./ Contempla el fuego que en sus ojos gira,/ considera que airado/ en ginete veloz se

56. Javier Portús, J. García-Máiquez, R. Dávila: «Los retratos ecuestres de Felipe III y Margarita de Austria de Veláz-quez para el Salón de Reinos» (art.), en Boletín del Museo del Prado, $\mathrm{n}^{\circ}$ XxIX, 2011, n 47, pp. 16-39.

57. John F. Moffit t: «An "Emblematization” of Philip IV in the Salón de Reinos» (art.), en Pantheon, n XlviII, 1990, pp. 70-75; Juan José L. Fernández: „Der Salón de Reinos des Buen Retiro-Palastes in Madrid“ (art.) en: op. cit., Bussmann, Schilling, pp. 121-129; op. cit., Brown, pp. 107-129, 121-129; Jonathan Brown (ed.): Velázquez, Rubens y Van Dyck, Madrid: Ediciones El Viso, 1999, pp. 136-139, (esp. 107-129), NC 8; JonAthan Brown: «The Hall of Realms and the Thirty Years' War» (cap.), en Ronald G. Asch, Wulf Eckart Voss, Martin Wrede (eds.): Frieden und Krieg in der Frühen Neuzeit. Die europäische Staatenordnung und die außereuropäische Welt, Múnich: Wilhelm Fink Verlag, 2001, pp. 207-214; Jonathan Brown, John H. Elliott: A Palace for a King. The Buen Retiro and the Court of Philip IV, New Haven: Yale University Press, 2003 (2ed.), pp. 141-202; José Álvarez Lopera: «The Hall of Realms: the Present State of Knowledge and a Reconsideration» (art.), en ANDRÉS ÚBEDA DE LOS Совоs (ed.): Painting for the Planet King. Philip IV and the Buen Retiro Palace, Madrid: Paul Holberton Publishing, 2005, pp. pp. 90-110; 112-119, NC 9-12 (cat. exp.); Fernando Marías: Pinturas de Historia, Imágenes políticas. Pensando el Salón de Reinos, Madrid: Real Academia de la Historia, 2012; op. cit., López-Rey, Delenda, pp. 360-362, nC 66-69; Mercedes López Simal: «El Real Sitio del Buen Retiro y sus colecciones durante el reinado de Felipe IV» (art.), en José Martínez Millán, Manuel Rivero Rodríguez (eds.): Arte, coleccionismo y sitios reales (La corte de Felipe IV (1621-1665): Reconfiguración de la Monarquía católica III/4), Madrid: Polifemo, 2017, pp. 2.339-2.566 (esp. 2.741-2.472).

58. Diego Covarrubias i Leyva (ed.): Elogios al Palacio Real del Bven Retiro, Madrid: Imprenta del Reyno, 1635.

59. Manuel de Gallegos: Obras varias al real palacio del Bven Retiro, Madrid: Maria de Quiñones, 1637, folios 2v-3v; vg., Jesús Ponce Cárdenas: «Pintura y Panegírico. Usos de la écfrasis en Manoel de Galhegos» (art.), en Versants, $n^{\circ} 65,2018, n^{\circ} 3$, pp. 97-123. 
ostenda armado. Si así le viera el belga en la campaña/ al Imperio de España/se rindieran las turbas rebeladas/ en rayos de decoro fulminadas». A pesar de la amable representación del paisaje, el retrato ecuestre de Felipe IV de Velázquez encarnaba, al igual que el de Rubens, la batalla de los Habsburgo contra los neerlandeses.

En estos dos cuadros, al sucesor del trono se le representaba como a un «exemplum de la majestad» y símbolo del buen gobierno del príncipe. En palabras del poeta cortesano: « ¿No ves como veloz, como ligera/ al bello Adonis de hermesura armado/ conduze à par del dia/ acanelada pia?» ${ }^{60}$ El retrato muestra al sucesor del trono irguiéndose con su caballo como todo un jinete, y con ello, «el perfecto dominio del animal se convierte en la expresión del buen gobierno» ${ }^{61}$ Ya en 1640, Diego de Saavedra Fajardo recurrió a esta idea [de representación] en un emblema de su tratado de instrucción para el infante. ${ }^{62}$ Qué tareas iban a esperarle en su gobierno al heredero al trono, eso fue lo que describió el poeta de la cámara real Antonio Hurtado de Mendoza en 1639 tras el juramento de las haciendas castellanas -quien por cierto era probablemente uno de los posibles redactores del programa de ornamento- de Baltasar Carlos, de entonces diez años de edad: «De resistir á tantos y tan declarados enemigos de la Iglesia y suyos y de la Augustissima Casa de Austria [...], la defensa de la Fe y del Imperio» ${ }^{63}$ Esta interpretación del retrato ecuestre de Velázquez lo confirman sobre todo dos tratados educativos dirigidos al príncipe habsburgo de los años 1640 y 1643. [Aquí] se observa el escrito abreviado de Saavedra bajo el título de Idea de un príncipe político Christiano [...], dedicado al príncipe de las Españas nuestro Señor sobre el frontispicio de la primera edición publicada en Múnich en 1640 y que evidencia la ideología del Salón de Reinos (Fig. 16). ${ }^{64}$ Dicho título del libro, presentado en un nicho a modo de ventana, está flanqueado por los retratos de Felipe IV y del Cardenal Infante. Las inscripciones «VIRTVTEM EX ME» y «EX ME LABOREM ET FORTVNAM» aparecen en sus zócalos y se refieren al padre y al tío del

60. op. cit., WARNKE, pp. 146-159.

61. op. cit, Pfisterer, p. 229. Relaciónese la interpretación con el retrato de Felipe IV.

62. M. a del Carmen H. Moreno, Juana Hidalgo Ogáyar: «Intercambio de regalos entre la realeza europea y mercedes reales por servicion prestados a la corona (1621-1640)» (art.), en De Arte, $\mathrm{n}^{\circ}$ 15, 2016, pp. 150-167 (esp. 159-160).

63. Antonio Hurtado de Mendoza: Ceremonial que se observa en España para el juramento de Príncipé hereditario, ó convocacion de las cortes de Castilla, segun se ha executado dese el juramento del Príncipe Nostro Sr. D. Baltasar Carlos, primero de este nombre, Madrid: Imprenta de Gonzales, 1789, p. 17. Es comprensible que el hijo ilegítimo y militarmente activo de Felipe IV, Don Juan José de Austria, fuera retratado de esta forma por José de Ribera ya en 1648, v. CARMEN ChecA García-FríAs, JAVIER Jordán de UrRíes y del Colina (eds.): El Retrato en las colecciones reales del Patrimonio Nacional. De Juan de Flandes a Antonio López, Madrid: Patrimonio Nacional, 2014, pp. 212-216, NC 29 (cat. exp.) (Gabriele Finaldi).

64. DieuwKe de Hoop Scheffer (comp.): Aegidius Sadeler to Raphael Sadeler. Hollstein Dutch E Flemish etchings, engravings and woodcuts 1450-1700, vol. xxI, Amsterdam: Van Gendt, 1980, p. 194, NC 13. 
infante como los modelos directos de virtud a imitar. Que fuera Múnich el lugar de publicación y la posición del autor como embajador de España en la corte bávara y diplomático en el Congreso de Paz de Münster, no deja lugar a dudas de [que se trataba de] la estrategia coordinada entre las dos ramas de la Casa de Austria. Esto también lo confirma el espejo de virtudes de Corona virtuosa y virtud coronada, en que se proponen los frutos de la virtud de un príncipe, juntamento con los heroicos exemplos de virtudes de la Casa de Austria y los reyes de España, publicado en Madrid en 1643 por el jesuita Eusebio Nieremberg. Pues esto no solo presenta el sabido paralelismo entre los exempla de la virtud desde Rodolfo I hasta Fernando II por el lado imperial, y desde Fernando el Santo a Felipe III por el lado español, ¡sino que además se publicó en Viena en 1675 en una versión en latín! ${ }^{65}$ Como muy tarde alrededor de 1646 se discutió oficialmente [el acuerdo de] un matrimonio entre Baltasar Carlos y su prima la archiduquesa María Ana, por Felipe IV e incluso el consejero de Estado español. ${ }^{66}$

En ambas ramas de la Casa de Austria, durante el segundo cuarto del siglo XVII, al retrato ecuestre se le consideraba abiertamente como el prototipo de retrato propiamente habsburgo y de su fortuna de batalla que estaba bajo protección divina. Esto también se demuestra por el grabado a cobre de 1653 en el que se representa a Fernando IV de Roma y al posible prometido de la infanta María Teresa como el nuevo Constantino (Fig. 17). ${ }^{67}$ Georg Lackner representó al sucesor del trono montado a caballo frente a una escena batalla con guerreros turcos. En el cielo aparece la doble cruz (húngara) con el lema «IN HOC SIGNO VINCES» («con este signo ganarás»), que equipara la batalla del romano y húngaro contra los otomanos y el triunfo del primer emperador cristiano sobre sus oponentes paganos. La imagen ideal del gobernante que, como Constantino, lucha con sus oponentes confiando en la cruz, fue un motivo central de la Pietas Austriaca y se remonta a Rodolfo ${ }^{68}{ }^{68}$

65. Acerca del autor, v. D. SCOtt Hendrickson: Jesuit Polymath of Madrid. The Literary Enterprise of Juan Eusebio Nieremberg (1595-1658), Boston: Brill, 2015.

66. Claudia Ham: Die Verkauften Bräute. Studien zu den Hochzeiten zwischen österreichischen und spanischen Habsburgern im 17. Jahrhundert, Viena: Dissertation der Universität Wien, 1995, pp. 169-182.

67. Friedrich Polleroß: Das sakrale Identifikationsporträt. Ein höfischer Bildtypus vom 13. bis zum 20. Jahrhundert Manuskripte zur Kunstwissenschaft 18, Worms: Wernersche Verlagsgesellschaft, 1988, Fig. 99; VV.AA.: Welt des Barock, Linz: Oö. Landesregierung, 1986, p. 72, NC 1.31.

68. op. cit., Coreth: Pietas Austriaca, 38-44. 


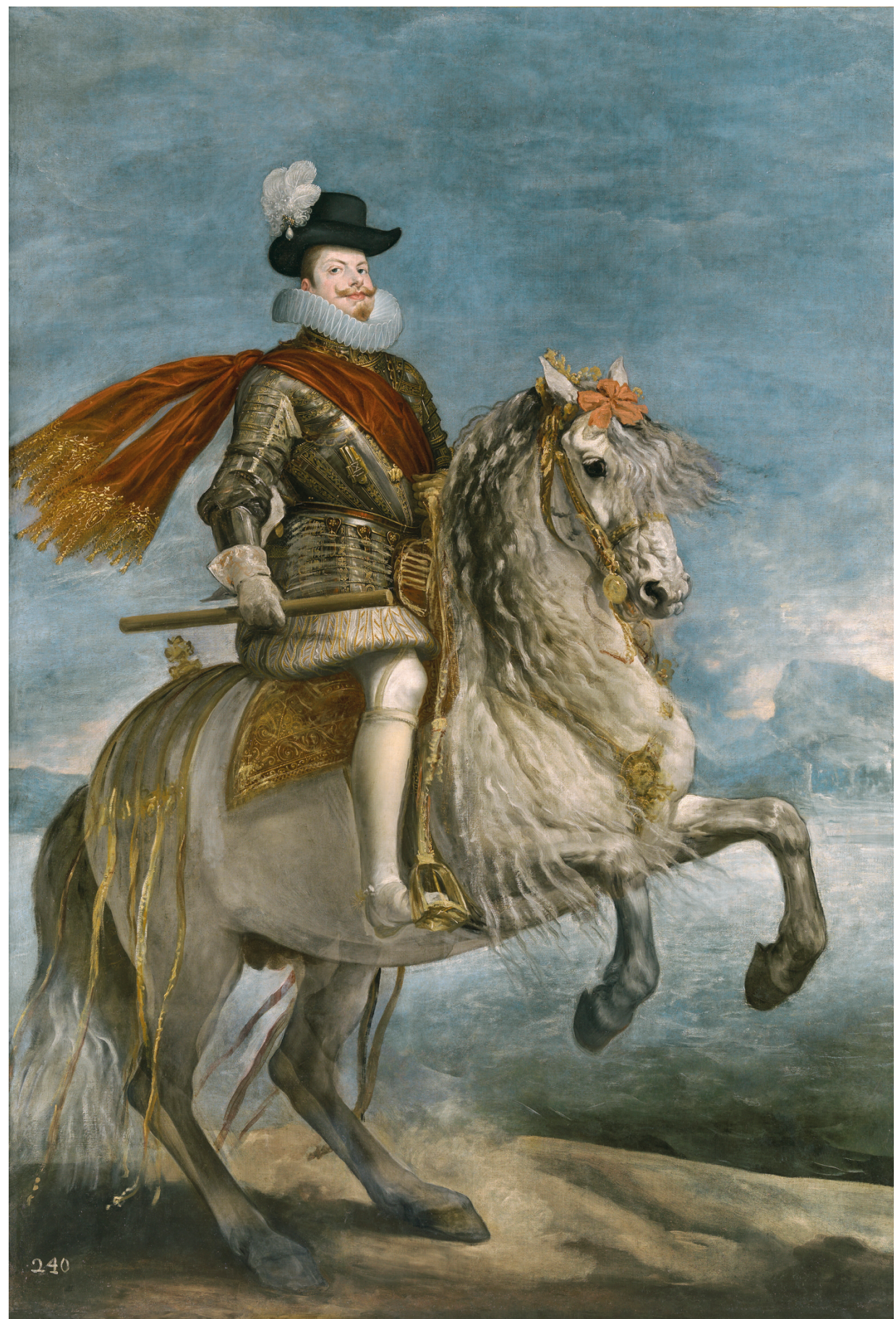

Fig. 13. Retrato de Felipe III, Diego Velázquez y taller, 1635, óleo sobre lienzo, Madrid, Museo Nacional del Prado 
Hacia 1668-1670 el pintor de la corte española Sebastián de Herrera Barnuevo realizó un retrato ecuestre del joven rey Carlos II (Fig. 18), en el que parafraseó directamente el retrato ecuestre de Baltasar Carlos de Velázquez y además retrató al joven habsburgo con la batuta. ${ }^{69} \mathrm{Un}$ retrato ecuestre suyo algo más temprano seguía, por el contrario, el modelo iconográfico del Cardenal Infante de Rubens; $;^{70}$ en ambos casos, el príncipe, que estaba enfermo desde el principio, debía presentarse ante el público crítico como un potencial líder militar. Un retrato a gran formato de este tipo probablemente estuviera destinado a continuar la serie de retratos de gobernantes de las dos residencias reales de Madrid, ya que era obvio que Carlos II asimismo debía emular a Carlos I (Carlos V) estéticamente. ${ }^{71}$ Paralelamente, o como contraparte de un retrato del rey algo más temprano de Francisco Rizi, el mismo pintor planeó la realización de un retrato ecuestre de la madre reina María Ana de Austria (o sea, la hermana del mencionado Fernando IV), que muestra a la regente con el traje de viuda y el bastón de mariscal (!) y a caballo, mientras la Fama está flotando por las nubes con la trompeta y la corona real. ${ }^{72}$ Del retrato solo ha sobrevivido el boceto de un dibujo, por lo que se puede suponer que, o bien no se ejecutó luego de la destitución de María Ana, o bien fue reemplazado por el retrato de la primera esposa del rey. ${ }^{73}$

Hasta qué punto el retrato ecuestre se ha convertido en un «logo familiar» habsburgo, se revela sobre todo por los retratos femeninos de representaciones de princesas a caballo, que tienden a ser poco habituales. ${ }^{74}$ Una excepción que confirma la regla, son las representaciones en serie de las duquesas de Borgoña y los estatúderes neerlandeses a caballo, que inicialmente habían sido ilustradas en manuscritos y eran habituales en grabados desde mediados del siglo XVI. Con los retratos de María de Borgoña, María de Hungría y Margarita de Parma, la corte española y sus artistas se hacían una idea de la iconografía que correspondía a estas. ${ }^{75}$ Ya en 1525 había aparecido una xilografía que representaba a caballo a Carlos V y a Fernando I, por un lado,

69. Álvaro Pascual Chenel: «Sebastián de Herrera Barnuevo y los retratos ecuestres de Carlos II durante su minoría de edad. Fortuna iconográfica y propaganda política» (art.), en Reales Sitios, $\mathrm{n}^{\circ} \mathrm{XLVI}$, 2009, n¹82, pp. 4-27 (esp. 4-12); op. cit., Pascual Chenel, pp. 431-447; op. cit., Mínguez, pp. 206-212; op. cit., SANCHO, Souto, p. 172.

70. Subasta «Alte Meister 24/04/2018», Lote $n^{\circ} 77$ : Dorotheum Viena.

71. Ya en 1666, una ilustración de un libro mostraba al príncipe frente a un monumento del emperador, v. op. cit., Souto, Sancho, Fig. 5.

72. op. cit., Souto, Sancho: pp. 54-55, Fig. 10.

73. Para el retrato ecuestre de Marie Louise d'Orléans, v. Álvaro Pascual Chenel: El retrato de Estado durante el reinado de Carlos II. Imagen y propaganda (Tesis Doctorales Cum Laude A/33), Madrid: FUE, 2010, pp. 574-575.

74. vgr., op. cit., LIEDTKE.

75. Sabine Haag, Dagmar Eichberger, Annemarie Jordan Gschwend (eds.): Frauen, Kunst und Macht, Viena, кнм, 2018, p. 38 (cat. exp.). La tradición se remonta al siglo xv, cuando María de Borgoña fue retratada a caballo como heredera del archiducado según el manuscrito Chronik von Flandern, v. op. cit., DE CAVI, pp. 137-140. 
y a sus hermanas Isabel, Juana, Catarina y María, por el otro ${ }^{76}$. Por lo tanto, no es de extrañar que un grabador de cobre de Estrasburgo como Abraham Aubry - que además de en esta ciudad, trabajaba en otras alemanas- se fijara en una aún más vieja hoja de papel en la que se mostraba a la reina francesa Ana de Austria, para un retrato a grabado de la esposa imperial María Margarita Teresa (Fig. 19). ${ }^{77} \mathrm{El}$ que estuviera rindiéndole homenaje a la futura emperatriz a través del retrato de un jinete, no es menos casual que el hecho de que tomara como modelo un retrato de su tía española. Igualmente, un modelo francés y, con ello, la representación de una infanta [sucesora] al trono francés, fue «copiado» y grabado [abgekupfert] al parecer, por el editor nuremburgués Johann Hoffman en 1666, para retratar a Leopoldo I y su esposa española a caballo. ${ }^{78}$

Tras este traslado de la tipología «feminista» de la corte española a la vienesa, era lógico que la idea de un encuentro monumental ecuestre entre los Habsburgo en la ópera nupcial de Il Pomo d'Oro en honor a Leopoldo I y su esposa española Margarita en 1668 fuera efímera, pero se convirtió en una forma artística imponente. La escenografía del prólogo de Ludovico Ottavio Burnacini titulada Teatro della gloria austriaca muestra en el centro de la perspectiva a Leopoldo I apoteósico, sobre un caballo en los cielos y coronado con la corona de laurel. El soberano está rodeado de una arquitectura con columnas corintias de mármol, entre las cuales se colocan, a cada lado, seis monumentos ecuestres dorados de sus antepasados o antecesores. Antes de estas, las personificaciones del Imperio, las Tierras Heredadas y los Territorios Españoles en Europa y América, parecen simbolizar el dominio mundial de la Casa de Habsburgo (Fig. 20)..$^{79} \mathrm{Al}$ igual que a su sobrino y cuñado en el Salón de Reinos, al joven gobernante a caballo se le representa tanto como sucesor de las virtudes de sus antepasados (con caballos al trote), como heredero de un dominio mundial.

76. Dieuw Ke De Hoop SCHEFFER: Vorstenportretten uit de eerste helft van de 16de eeuw. Houtsneden als propaganda, Amsterdam: Rijksmuseum,1972, NC 4, Fig. (cat. exp.).

77. op. cit., Polleroß, Fig. 23, Fig. 24. No es por otra parte sorprendente, que el primer retrato ecuestre de Luis XIV de Charles Le Brun nos llegara en forma de copia no por casualidad, sino más bien siguiendo el modelo de retrato de Rubens realizó de su suegro en Madrid a plena consciencia, $v$. DAMIEN BRIL: «A la curiosité des genres. Louis XIV et le portrait équestre» (art.), en Artibus et Historiae, $\mathrm{n}^{\circ} \mathrm{XXXV}$, 2014, n 69, pp. 213-231.

78. Milan Pelc: «Der Sammler und sein Kaiser. Leopold I. in der Sammlung Valvasor - Die Ikonographie des Kaisers aus der Perspektive eines adeligen Zeitgenossen» (art.), en Werner Telesko (ed.) : Die Repräsentation der Habsburg-Lothringischen Dynastie in Musik, visuellen Medien und Architektur Representing the Habsburg-Lorraine Dynasty in Music, Visual Media and Architecture 16181918, Weimar: Böhlau, 2017, pp. 231-250 (esp. 238-239), Fig. 4. Puede compararse con el doble retrato ecuestre de Luis XIII y Ana de Austria (1639), vgr., op. cit., BrIL, Fig. 4.

79. Friedrich Polleroß (ed.): Federschmuck und Kaiserkrone. Das barocke Amerikabild in den habsburgischen Ländern, Viena: Künstlerhaus, 1992, NC 7.18 (Andrea Sommer-Mathis) (cat. exp.). 


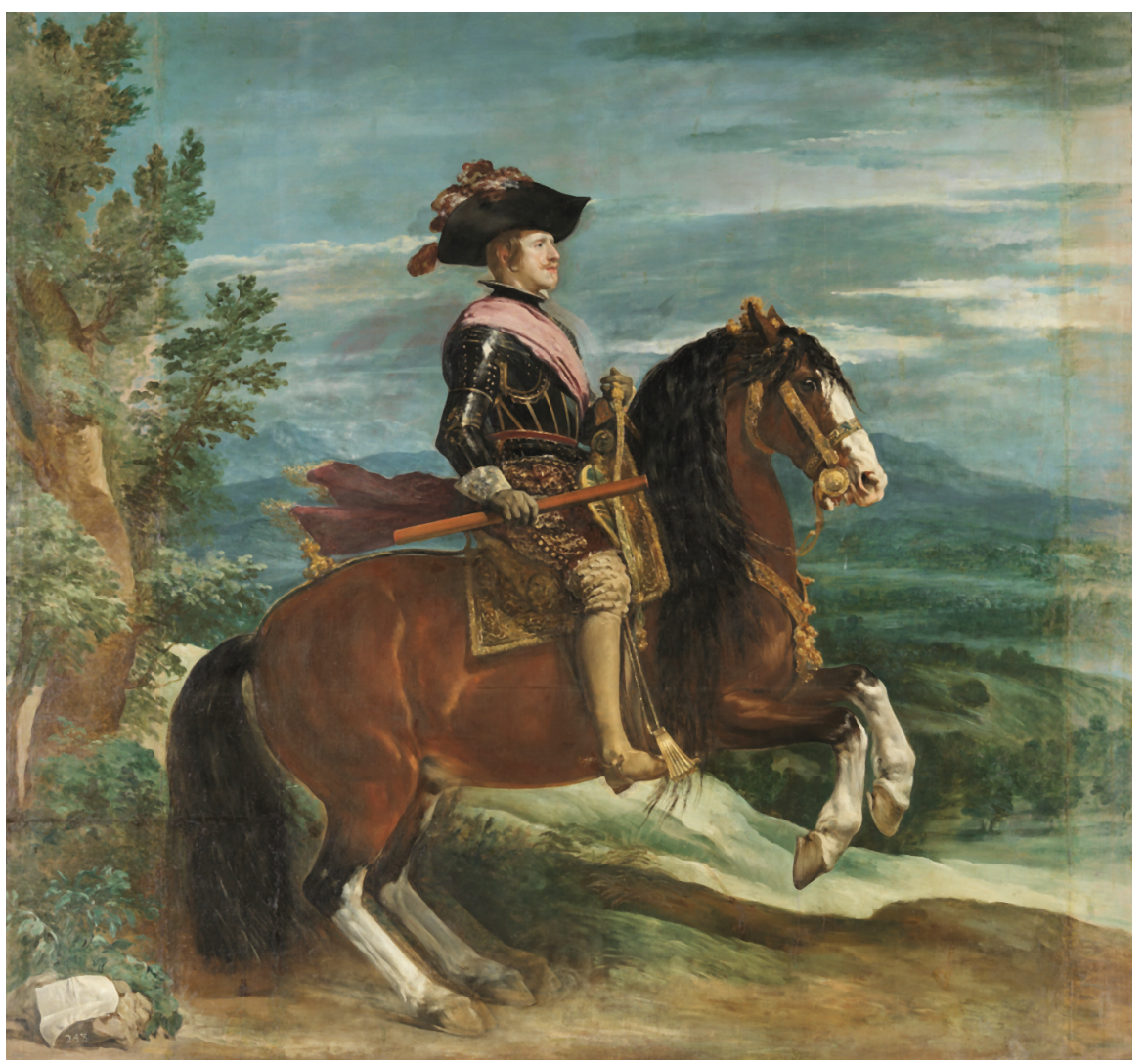

Fig. 14. Retrato de Felipe IV, Diego Velázquez, circa 1635, óleo sobre lienzo, Madrid, Museo Nacional del Prado

La razón de las representaciones de Leopoldo I como un triunfante desde 1683 se debe sobre todo a las victorias de los ejércitos cristianos sobre los otomanos. Como el gobernante huyó de la ciudad sitiada y más tarde no participó en ninguna otra batalla, la propaganda de la época proclamaba que el habsburgo habría apoyado a sus tropas con su oración. Más allá de este tema, los éxitos militares en Hungría se celebraron cual triunfo del occidente cristiano sobre el islamismo otomano, y el emperador [aparecía] en folletos y grabados populares representados a caballo en la batalla y como «empereurs de guerre». ${ }^{80}$ Una hoja de tesis por J. Schormer y Johann Franz Samuel Wussim (Viena, 1687) firmado

80. Maria Goloubeva: The Glorification of Emperor Leopold I in Image, Spectacle and Text, Mainz: Philipp von Zabern, 2000, pp. 122-141 („Conquering the Thracian: the Emperor's Image and the Turkish Campaigns“); MARTIN WREDE: «Türkenkrieger, Türkensieger. Leopold I. und Ludwig XIV. als Retter und Ritter der Christenheit» (cap.), en Christoph Kampmann (ed.): Bourbon, Habsburg, Oranien. Konkurrierende Modelle im dynastischen Europa im 1700, Colonia: Köln, 2008, pp. 149 -165; MARTIN WREDE: «Die ausgezeichnete Nation. Identitätsstiftung im Reich Leopolds I. in Zeiten von Türkenkrieg und Türkensieg, 1663-1699» (art.), 
Illlinc protegeris Virtute hinc Numine Caesar: Tutior ad Lauros non valet esse via, muestra a Leopoldo I a caballo sobre dos patas frente a una escena de batalla y vestido con el traje antiguo (Fig. 21). La ayuda divina se ilustra con un ángel con una espada de fuego y el escudo húngaro, así como con el águila de Júpiter y un haz de relámpago y, encima de ellos, la personificación de la Divina Providencia queda entronizada. El grabado copiaba indirectamente una hoja de tesis francés con el retrato del rey francés Luis XIV, ${ }^{81}$ aunque la iconografía del patrón protector celestial ya había sido utilizada antes en el retrato del Cardenal Infante.

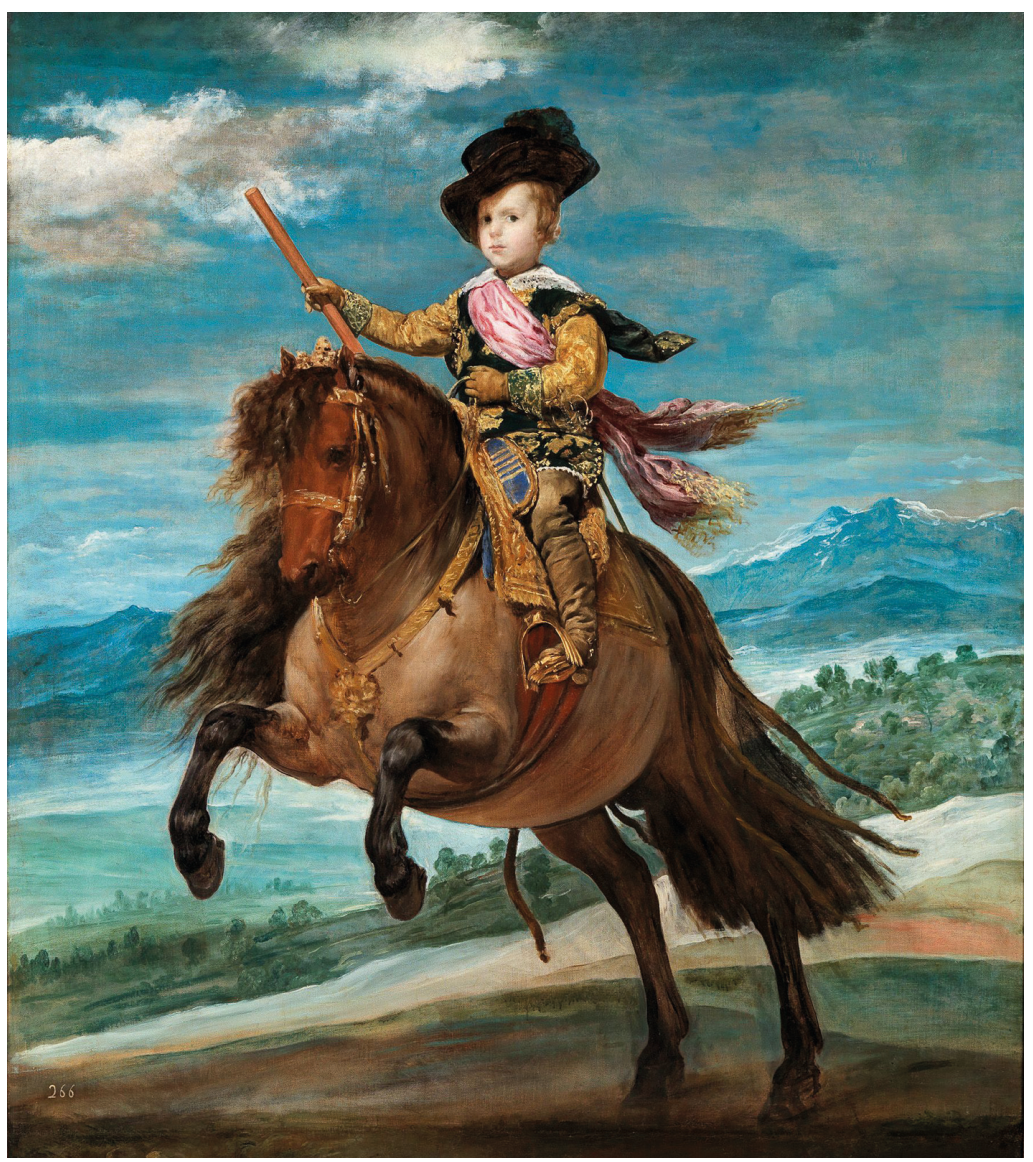

Fig. 15. Retrato ecuestre del infante Baltasar Carlos, Diego Velázquez, 1634/5, óleo sobre lienzo, Madrid, Museo Nacional del Prado

en Eckhard Leuscher, Thomas Wunsch (ed.): Das Bild des Feindes. Konstruktion von Antagonismen und Kulturtransfer im Zeitalter der Türkenkriege, Berlín: Gebr. Mann Verlag, 2013, pp. 19-31.

81. Friedrich Polleroß: «Paraphrases artistiques ou contre-images politiques? Les empereurs et les rois de France dans des gravures parallèles» (art.), en: Bulletin du Centre de recherche du château de Versailles, 03 avril, 2018, URL:https://journals.openedition.org/crcv/14924 pp. 1-33, fig. 12. 


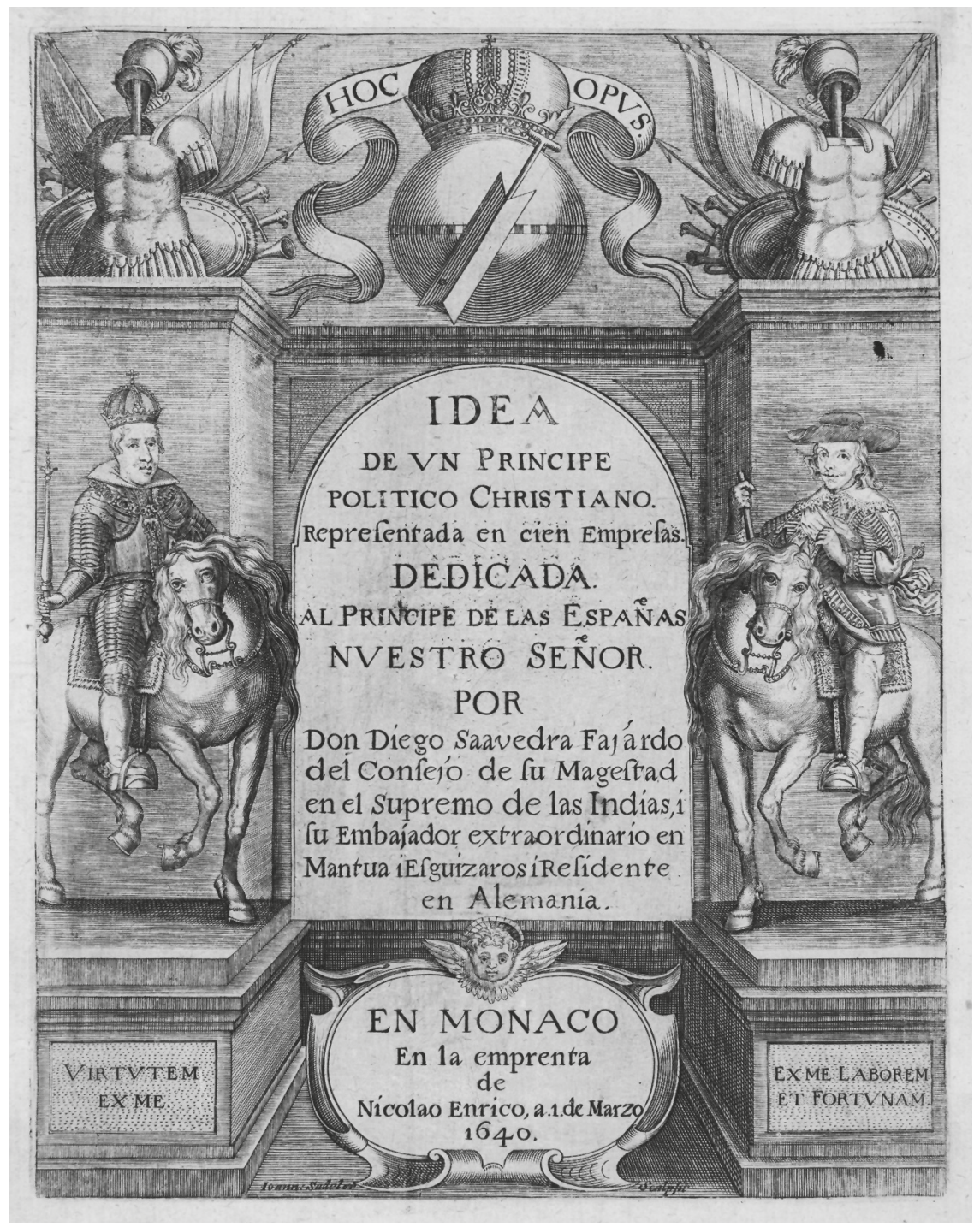

Fig. 16. Frontispicio del libro «Idea de un Principe político Christiano» de Diego de Saavedra Fajardo, grabado en cobre por Jan Sadeler, 1640, Colección Friedrich Polleroß

Tras las victorias sobre los otomanos y la coronación de José I, la serie de estatuillas ecuestres de Viena prosiguió en la cámara de arte imperial, con [la introducción de] pequeños monumentos de Leopoldo I y José I realizados por Matthias Steinl en marfil (Fig. 22) -como prefería Leopoldo I-, y no en bronce, género de talla propio del Barroco alto. ${ }^{82}$

82. Eleonore Pühringer-Zwanowetz: Matthias Steinl, Viena: Herold, 1966, pp. 42-54; SABINE HAAG: „...Das artigste...alss ich mein tage wass gesehen habe.... Elfenbeinkunst im kaiserlichen Wien der 


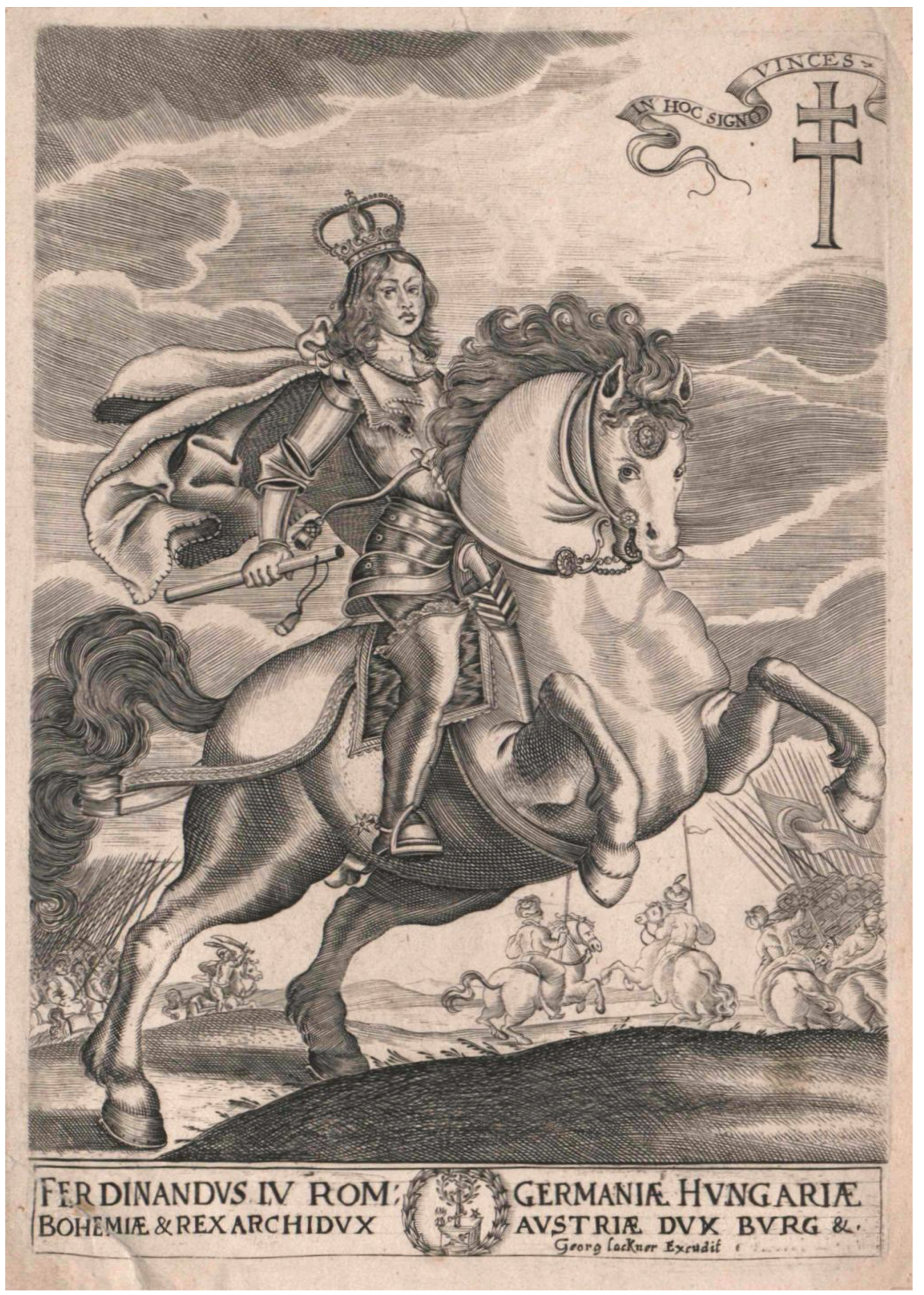

Fig. 17. El rey Fernando IV como emperador Constantino el Grande, Georg Lackner, 1653, grabado en cobre, Viena, ÖNB Bildarchiv, Inv.-Nr. Pg 158.149/1 in Ptf. 125

Barockzeit (cap.), en Maraike Bückling, Sabine HaAg (eds.): Elfenbein Barocke Pracht am Wiener Hof, Fráncforf del Meno: Liebighaus, 2011, pp. 14-31. 


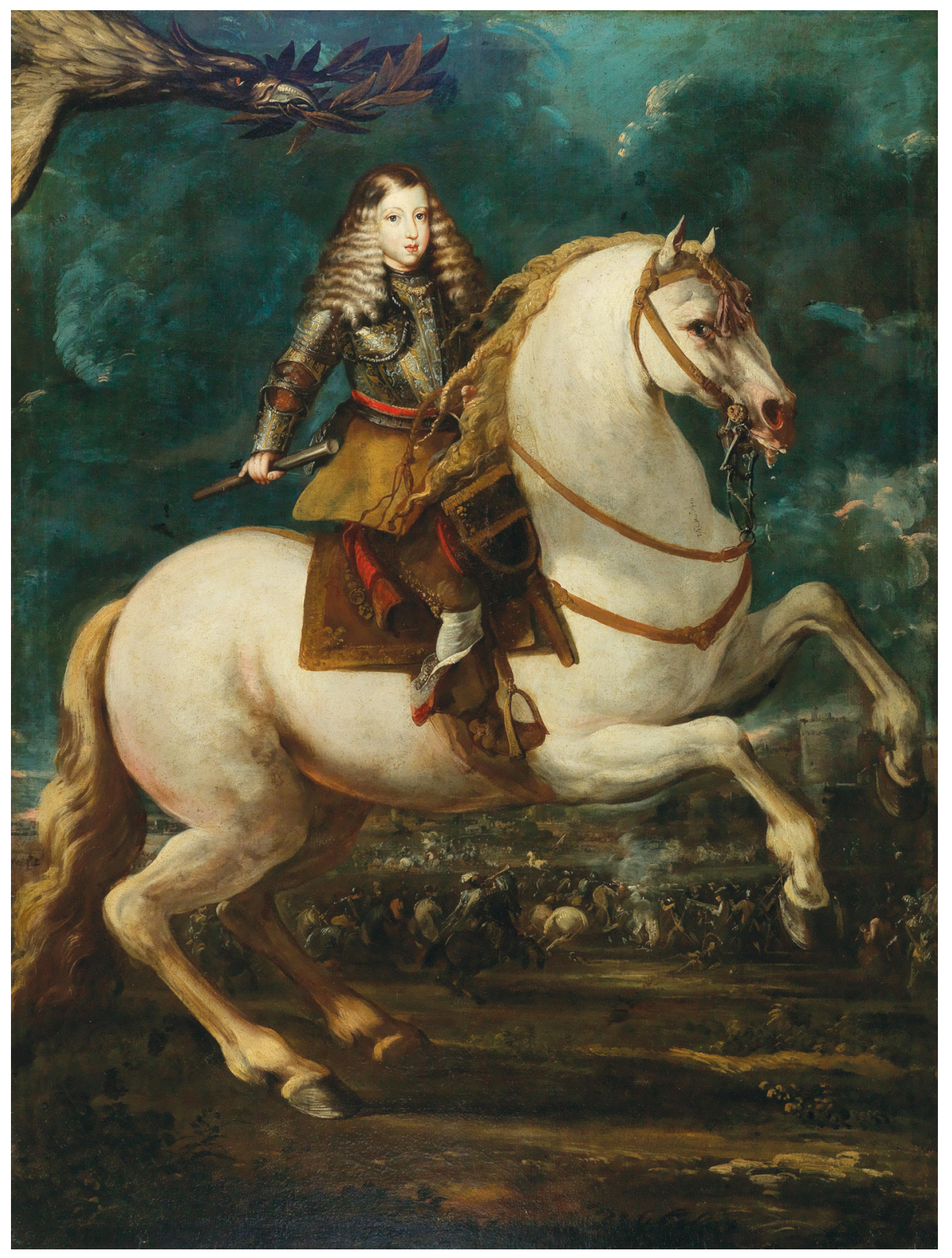

Fig. 18. Retrato ecuestre del rey Carlos II, Sebastián Herrera Barnuevo, circa 1675, óleo sobre lienzo, Dorotheum Viena 
A esta le siguió la serie de pinturas a tamaño natural del Salón de Espejos del Alcázar de Madrid. Como muy tarde en 1694 debieron colgarse los retratos ecuestres de Carlos II y su segunda esposa Mariana de Neoburgo de Luca Giordano -siguiendo el ejemplo flamenco de la monumentalidad y la alegoría de la $\mathrm{Fe}-$, a modo de contrapiezas de las pinturas que Rubens realizó de Carlos V y Felipe IV ${ }^{83}$ Así, el retrato ecuestre se convertía finalmente en el sello distintivo de la línea española habsburga, y era lógico que se recurriera a esta tipología cuando el archiduque Carlos fue nombrado sucesor del rey español en $1703 .^{84}$ Un grabado austríaco anónimo a cobre de [ca.] 1703 precisamente sigue al retrato ecuestre de Carlos II de Jacob Peeters en Amberes de en torno 1670, tanto en términos de composición por el caballo, como por la vestimenta del jinete (manto y sombrero de plumas). ${ }^{85}$ Hay, sin embargo, ejemplos con el caballo sobre dos patas: un grabado de cobre de alrededor de 1670 muestra al joven gobernante español frente a una escena de caza, mientras que un grabado del artista francés Henri Bonnart (?) datado alrededor de 1703 retrata al archiduque Carlos como «CAROLUS III. Hispaniarum et Indiarum Rex» a caballo frente a una batalla naval con el manto español y el sombrero de plumas. ${ }^{86}$

83. op. cit., Chenel, pp. 448-453, 580-581; ANdrés Úbeda DE los Cobos: «Luca Giordano y Carlos II» (art.), en Fernando Checa Cremades (ed.): Cortes del Barroco da Bernini y Velázquez a Luca Giordano, Madrid: SEACEx, 2003, pp. 73-84, (esp. 77-78), Fig. 5.3.-5.5. (cat. exp.).

84. Para la iconoclastia durante la Guerra de Sucesión española, v. Hubert Winkler: Bildnis und Gebrauch. Zum Umgang mit dem fürstlichen Bildnis in der frühen Neuzeit. Vermählungen Gesandtschaftswesen - Spanischer Erbfolgekrieg (Dissertationen Universität Wien, 239), Viena: Universidad de Viena, 1993, pp. 221-251; Friedrich Polleroß: «Hispaniarum et Indiarum Rex. Zur Repräsentation Kaiser Karls VI. als König von Spanien» (art.), en: Jordi JanÉ (ed.): Denkmodelle. Akten des 8. Spanischösterreichischen Symposions 13.-18.Dezember 1999 in Tarragona, Tarragona: Universitas Taragonensis, 2000, pp. 121-175 (esp. 133), Fig. 5; Diane H. Bodart: „Philippe V ou Charles III? La guerre des portraits à Rome et dans les royaumes italiens de la couronne d'Espagne, en Antonio Álvarez-Ossorio, Bernardo J. García García, Virginia León (eds.): La pérdida de Europa. La guerra de Succesión por la Monarquía de España, Madrid: Carlos de Amberes 2007, pp. 99-133; Friedrich Polleroß: Die Kunst der Diplomatie. Auf den Spuren des kaiserlichen Botschafters Leopold Joseph Graf von Lamberg (16531706). Petersberg: Michael Imhof Verlag 2010, pp. 373-412.

85. Friedrich Polleroß: «Soberanía e imagen dinástica en la política artística de los Habsburgo ante la crisis sucesoria española. Paralelismos y diferencias» (art.), en BERnARdo J. GARCía GARCía (ed.): En nombre de la paz. La Guerra de Sucesión Española y los Tratados de Madrid, Utrecht, Rastatt y Baden 1713-1715, Madrid: Fundación Carlos de Amberes 2013, pp. 77-89, Fig. 11, Fig. 12 (cat. exp.).

86. op. cit., Chenel, Fig. 16; op. cit., Polleroß, Fig. 28-29. 


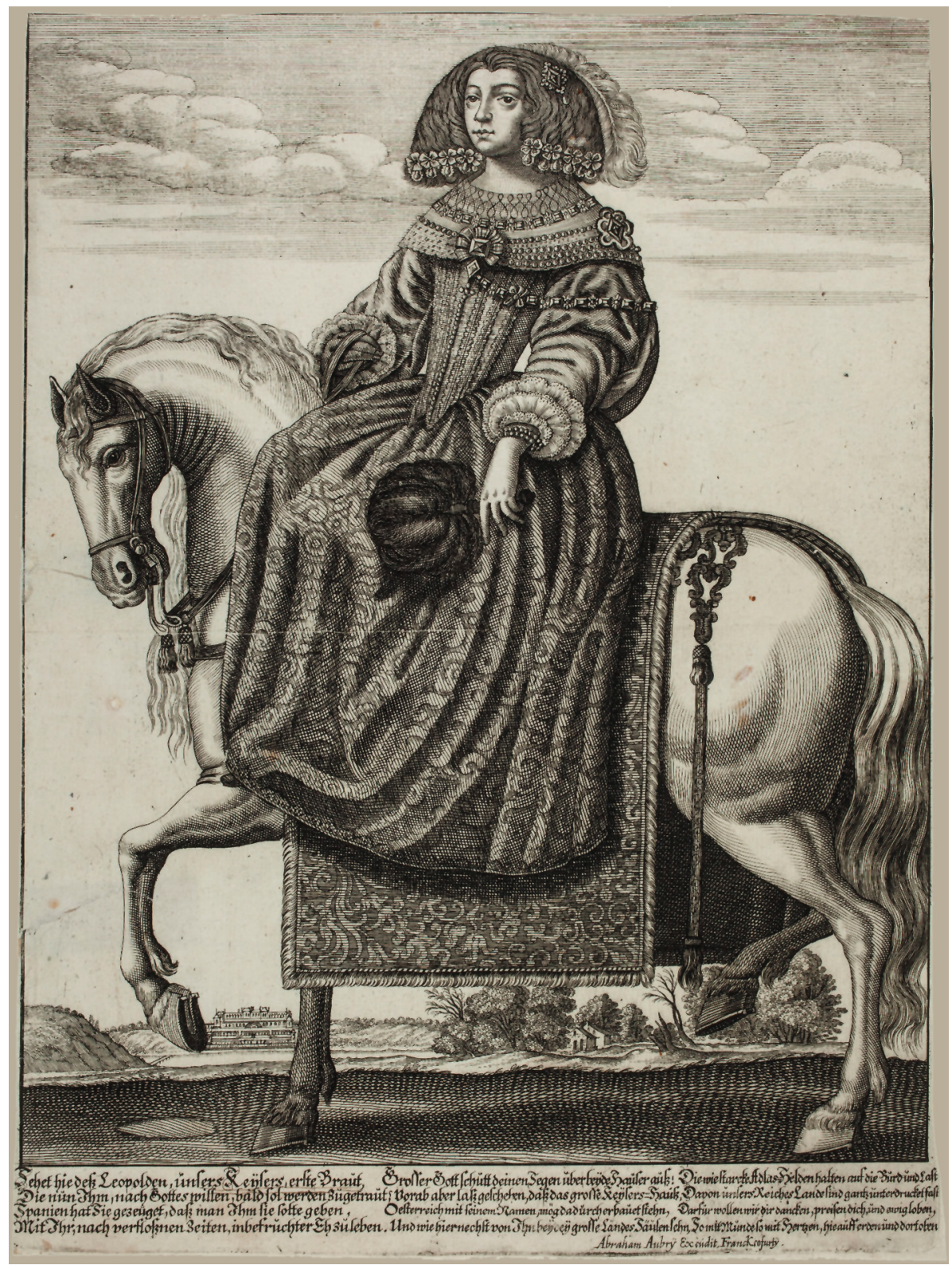

Fig. 19. Retrato ecuestre de Margarita Teresa de Austria, Abraham Aubry, circa 1666, grabado en cobre, Colección Friedrich Polleroß 
Después de 1712, Carlos VI añadió su propio monumento de cámara de arte a la serie de monumentos de marfil de Matthias Steinl. ${ }^{87}$ Y en $1727 / 28$, en la sala imperial de los canónigos agustinos de San Florián, expresamente dedicada al triunfo habsburgo sobre los otomanos ${ }^{88}$ se colocaron finalmente sobre las chimeneas dos retratos ecuestres de gran formato: uno muestra al príncipe Eugenio de Saboya y el otro al emperador Carlos VI. ${ }^{89}$ Es digno de mención que al emperador se le representara aquí con la coraza y el tricornio, o sea, en una forma aún inusual de uniforme de campo (Fig. 23).

Aun cuando la tipología del retrato ecuestre fuera generalmente apreciada y estuviera ampliamente extendida entre príncipes y nobles, pudiendo verse como una seña de identidad invididual o familiar, al mismo tiempo era utilizada en San Florían a plena consciencia, tanto para el caso de las victorias habsburgas contras los infieles con la ayuda de Dios como desde Carlos V y el surgimiento de este género.

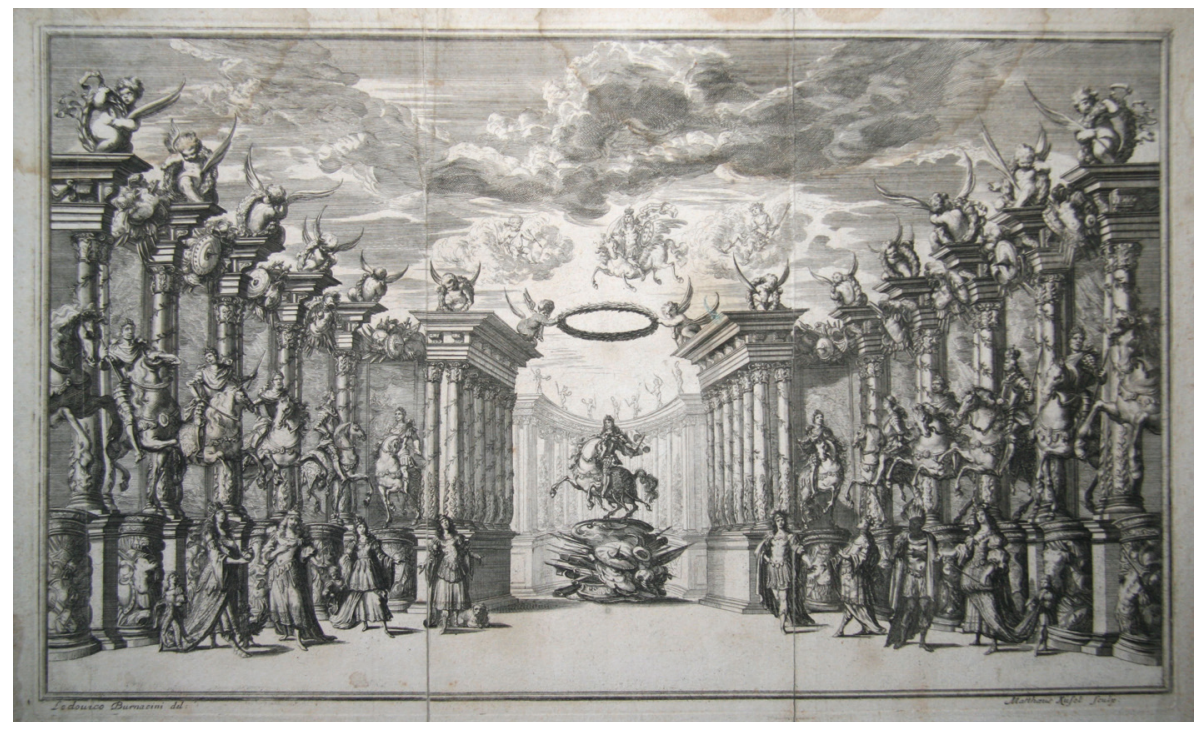

Fig. 20. Teatro della Gloria Austriaca para el prólogo de la obra «Il Pomo d’oro», Matthäus Küsel según Ludovico Ottavio Burnacini), 1668, grabado en cobre, Colección Friedrich Polleroß

87. op. cit., Steinl PÜhringer-Zwanowetz. pp. 55-56; op. cit., BüCKling, Mareike, pp. 134-139.

88. Werner Telesko: «Der „Marmorsaal“ im Augustiner-Chorherrenstift St. Florian. Die Verherrlichung des Türken-siegers Kaiser Karls VI. im Lichte schriftlicher und bildlicher Quellen» (art.), en Jahrbuch des oberösterreichischen Musealvereines, $\mathrm{n}^{\circ}$ 158, 2013, pp. 211-258.

89. Отто Wutzel: Das Augustiner-Chorherrenstift St. Florian, Linz: Rudolf Trauner, 1998, Fig. 115116; Friedrich Polleroß: «Karl Vi. im Porträt - Typen \& Maler» (art.), en Stefanie Hertel, FranzStefan Seitscheк (eds.): Herrschaft und Repräsentation in der Habsburgermonarchie, Berlín, 2021, pp. 347-373. 


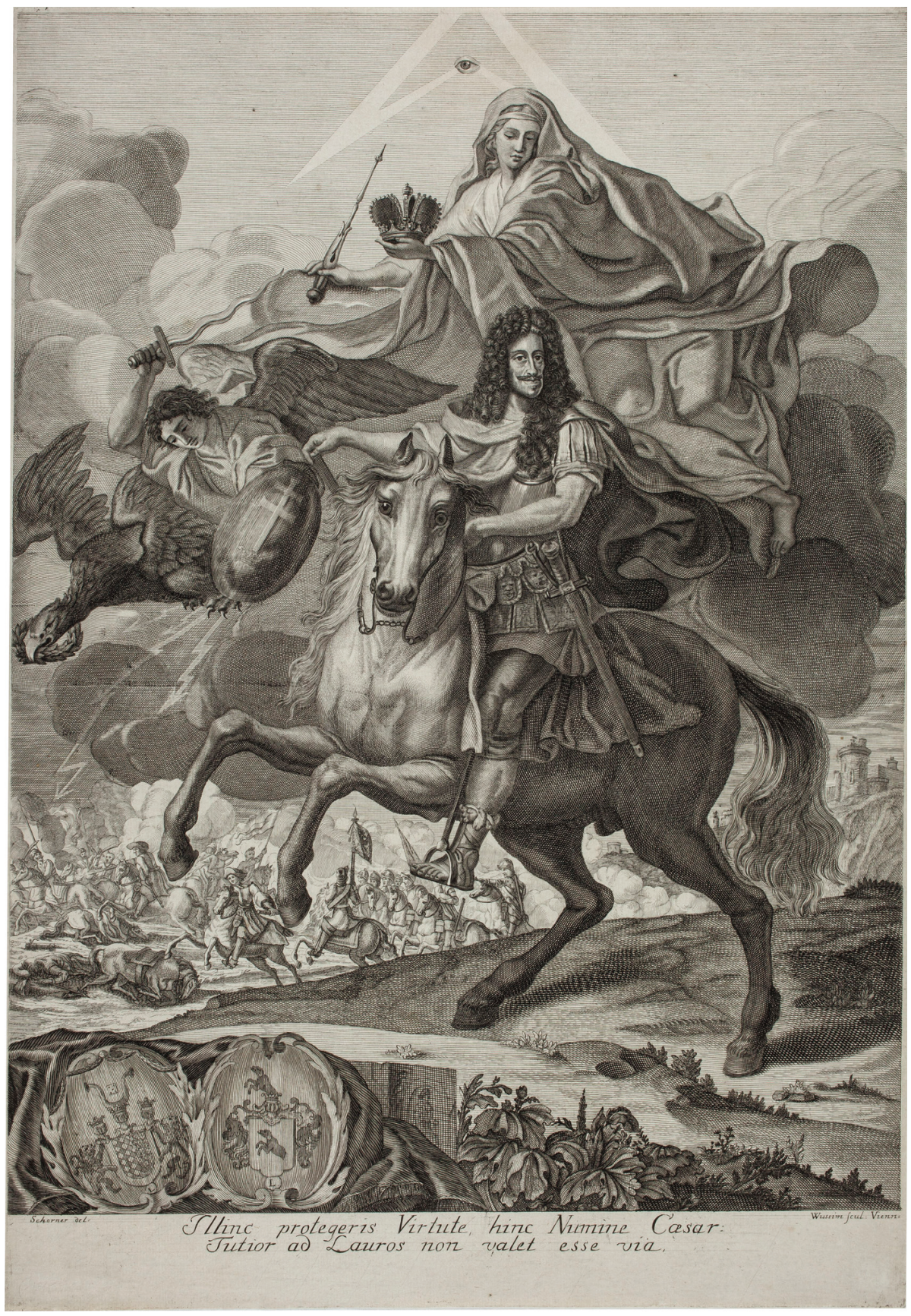

Fig. 21. Emperador Leopolgo como vencedor contra los turcos, J. Schormer según Johann Franz Samuel Wussin, 1687, grabado en cobre, Colección Friedrich Polleroß 


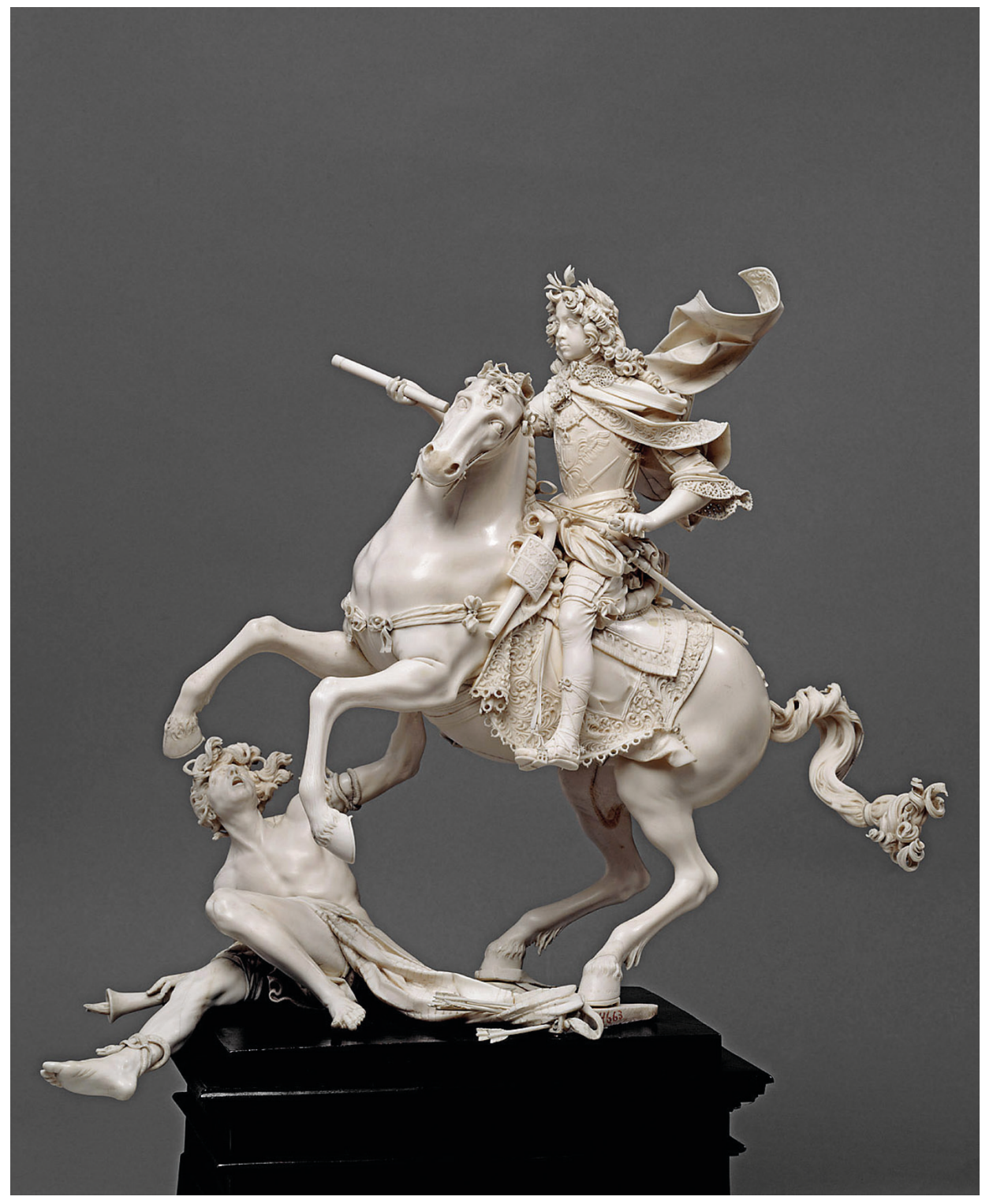

Fig. 22. Estatua ecuestre de José I, Matthias Steinl, circa 1690/93, marfil, Viena, KHM, Kunstkammer 


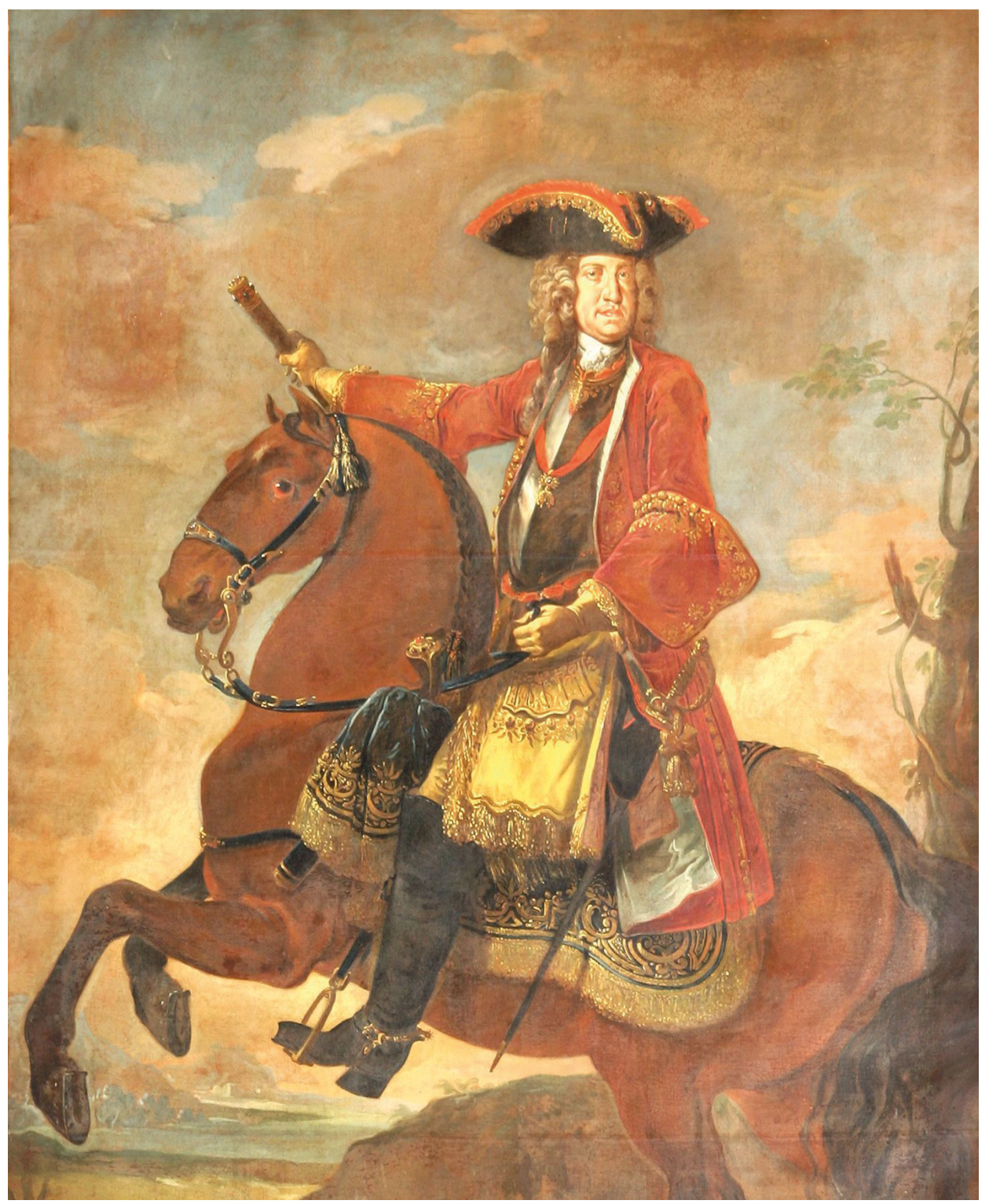

Fig. 23. Retrato ecuestre de Carlos IV como vencedor contra los turcos, anónimo, circa 1730, Sala del Emperador, Abadía San Florián 


\section{„VirTUS CORONATA EX AUgUSTISSIMA ET SERENISSIMA DOMO Austriaca et Hispana“" Das Reiterporträt als Herrschaftszeichen der Habsburger}

Bereits Kaiser Maximilian I. hat sich seit seiner Proklamation zum Römischen Kaiser in Trient im Jahre 1508 mit dem Gedanken eines Reiterstandbildes nach dem Vorbild des Marc Aurel auf dem Kapitol in Rom getragen. Das Denkmal, dessen Entwurf von Hans Burgkmair d. Ä. nach einem Konzept des Humanisten Konrad Peutinger erhalten blieb, verband allerdings die antike Ruhmesdarstellung mit der Funktion eines Stifterbildes und der christlichen Memoria ${ }^{2}$. Das als „Epitaphium“ bezeichnete Monument sollte nämlich neben oder in dem von Maximilian finanzierten Chor der Kirche St. Ulrich und Afra in Augsburg errichtet werden. Die Ausführung wurde Gregor Erhart übertragen, das Denkmal blieb aber unvollendet ${ }^{3}$. Der Habsburger wurde nicht nur in der Inschrift als „Imperator Caesar" bezeichnet, sondern auch mit Kaiserkrone sowie Reichsapfel abgebildet und damit war auch der Bezug auf das römische Monument naheliegend. Das erhobene Schwert visualisiert hingegen wohl den Eifer Maximilians als Protektor der Christenheit. Die wichtigste Information über das Augsburger Reiterdenkmal wurden im „Fuggerschen Ehrenspiegel“ von Clemens Jäger aus der Mitte des 16. Jahrhunderts überliefert, und da man in diesem Werk auch über ein Reiterdenkmal zu Ehren Rudolf I. berichtet hat (Abb. 1), kann man vielleicht davon ausgehen, dass auch dieses Standbild mit erhobenem Schwert eine Anregung für Maximilian bildete. Die Bürger von Straßburg hatten es 1266 auf dem Marktplatz ihrer Stadt aus Dankbarkeit für die Unterstützung im Kampf gegen den Bischof für die städtischen Freiheiten zu Ehren Rudolfs von Habsburg errichtet lassen: „Rudolphus und dem habspurgischen [!] geslecht zu einer ewigen gedächtnus, ein schöns Epitaphium, nemlich ain groß stainen pferde, darauf ein gewapneter Kinig mit gezogenem unnd erheptem schwert" und der Inschrift "'Rudolpho Victorioso Comiti in Habspurg. S.P.Q. Argentinens. Praefect. Strenno, Statuam hanc Equest. pp. M.CCLXVI.“ 4

1. Verkürzte Version des lateinischen Titels des Buches des Jesuiten Juan Eusebio Nieremberg, das ursprünglich 1643 in Madrid in spanischer Sprache und 1675 in Wien in lateinischer Übersetzung erschienen ist.

2. Zur Gattung siehe zuletzt: Poeschke, Joachim/ Weigel, Thomas/ Kusch-Arnhold, Britta (eds.): Reiterstandbilder von der Antike bis zum Klassizismus (Praemium Virtutis III). Münster: Rhema 2008; Keller, Ulrich: Reiterstandbild. In: Flecker, Uwe/ Warnke, Martin/ Ziegler, Hendrik (eds.): Politische Ikonographie. Ein Handbuch. 2. Band, München: C.H. Beck, 2. Auflage 2014, pp. 301-307.

3. Eva Michel/ Maria Luise Sternath (eds.): Kaiser Maximilian I. und die Kunst der Dürerzeit, AK Wien. München/ London/ New York: Prestel 2012, pp. 348-355; Heidrun Lange-Krach (ed.): Maximilian I. 1459-1519. Kaiser, Ritter, Bürger zu Augsburg, Ausstellungskatalog Augsburg. Regensburg: Schnell \& Steiner 2019, pp. 296-297.

4. München, Bayerische Staatsbibliothek, Clm. 895, folio 97v. 
Die 1668 im Auftrag Kaiser Leopolds I. veröffentlichte Druckfassung dieses Werkes berichtet darüber hinaus, dieses Monument habe nicht nur die Tradition der römischen Denkmäler aufgegriffen, sondern auch auf die kaiserliche Würde Rudolfs und seiner Nachkommen vorausgewiesen: „Die Burger zu Straßburg/ damit sie ein gedächtniß und beyspiel der dankbarkeit den Nachkommen hinterliessen/ liessen vier Jahre hernach/ ,Rudolpho' als ihrem Erlöser und Schutzherrn/ ein Ehrenbild oder ,Statuam' in ihrer Stadt aufrichten/nämlich die gekrönte Bildniß eines Ritters zu Pferd/ mit gezucktem Schwerd/ aus Stein gehauen/ samt einer Unterschrifft [...] ,Diß hält nicht der Helden Ruhm/ wann er steht in Stein gehauen:/ Marmor kan die Zeit zermalmen/ Steine stehn ewig nicht./ Rudolf eine Ehrenseule ihm hat selber zugericht:/ weil sein ewigs Ostenhaus seine Tugend noch lässt schauen. In diesem stuck haben der löbliche Raht und Bürgerschafft zu Straßburg den Römern nachgeahmet/ welche ihren wolverdienten Kriegsfürsten dergleichen Statuas Equestres oder Ritterseulen offentlich zu widmen pflegten: wovon beym Lazio und Rosino zu lesen ist. Sie haben aber auch dadurch/ indem sie unsern Rudolphum auf Römisch geehret/ unwissend gleichsam ein Vorzeichen aufgestellet/ daß die Römische Kron dermaleinst auf ihn und seine Nachkommen erben würde.."5

Beide Linien der Familie haben im frühen 17. Jahrhundert auf diese Repräsentationsform zurückgegriffen. Es handelte sich jedoch um Monumentalskulpturen, die nicht auf einem öffentlichen Platz, sondern im Garten einer Residenz aufgestellt wurden. Dies gilt sowohl für das um 1625 geschaffene, aber wegen des frühen Todes des Auftraggebers nicht mehr vollendete Monument Erzherzog Leopolds von Caspar Gras in Innsbruck ${ }^{6}$ (Abb. 2), als auch für das von Giambologna und seinem Meisterschüler Pietro Tacca 1606-16 ausgeführte Reiterstandbild von Philipp III. im Garten der Casa de Campo 7 . 1634-40 entstand nach dem Gemälde von Velázquez das im Garten des Buen Retiro Palastes aufgestellte Denkmal König Philipps IV. von Tacca (Abb. 3), das zu Unrecht und zum Nachteil des Innsbrucker Reiterdenkmals als das erste Standbild mit der technisch schwierigen Darstellung eines stei-

5. von Birken, Sigismund: Spiegel der Ehren des Höchstlöblichen Kayser= und Königlichen Ertzhauses Österreich [...]. Nürnberg: Michael und Johann Friedrich Endter 1668, pp. 62-64.

6. Liedtke, Walter: The Royal Horse and Rider. Painting, Sculpture and Horsemanship 15001800. New York: Abaris Books 1989, pp. 212-213, ill. 76; Rosenauer, Artur (ed.): Spätmittelalter und Renaissance (Geschichte der bildenden Kunst in Österreich 3), München u.a.: Prestel 2003, p. 393, cat.nr. 186 (Cornelia Plieger); Katalog Ibk 2020.

7. Watson, Katharine: Pietro Tacca. Successore to Giovanni Bologna, Garland Publishing New York/ London 1983, pp. 226-260; Falletti, Franca (ed.): Pietro Tacca. Carrara, la Toscana, le grandi corti europee, Ausstellungskatalog Carrara, Firenze: Mandragora 2007, pp. 54-73 und cat.-nr. 18. Zur künstlerischen Herkunft und politischen Tradition des Denkmals siehe: Mack-Andrick, Jessica: Pietro Tacca. Hofbildhauer der Medici (1577-1640). Politische Funktion und Ikonographie des frühabsolutistischen Herrscherdenkmals unter den Großherzögen Ferdinando I., Cosimo II. und Ferdinando II., Weimar: VDG 2005. 
gendem Pferd gilt ${ }^{8}$. Hinzuweisen ist vor allem auf die Tatsache, dass sowohl der teilweise in spanischen Diensten gegen die Protestanten kämpfende Tiroler Landesfürst als auch der spanische König als Feldherr in militärischer Kleidung bzw. mit Kommandostab porträtiert wurden.

Nachdem den dreidimensionalen Monumenten und ihren politisch wie künstlerisch vielfältigen Einflusssphären ${ }^{9}$ ebenso viel Aufmerksamkeit der Forschung geschenkt wurde wie den spanischen Gemälden dieses Typus ${ }^{10}$, soll hier ein vergleichender Überblick über die Anwendung des Typus an den Höfen in Wien sowie in Madrid und über die dahinter stehende Ideologie geboten werden ${ }^{11}$. Eine Voraussetzung für beide Gattungen bildet das für die spanische sowie österreichische Linie der Familie charakteristische hippologische Interesse und die Begeisterung für die spanische Hofreitschu$l e^{12}$. Dies manifestierte sich etwa schon 1581 im ersten illustrierten ,Sammlungskatalog' der Habsburger: Juan de Austria, der uneheliche Sohn Karls V., ließ nämlich damals von Jan van der Straet eine Kupferstichserie seiner wertvollsten Pferde anfertigen ${ }^{13}$. Und die Porträts des Velázquez bzw. Alonso

8. Hellwag-Konkerth, Karin: „La estatua ecuestre de Felipe IV de Pietro Tacca y la fachada del Alcázar de Madrid“. Archivo Español de Arte 250/ 1990, pp. 233-241; Manuel Matilla, José: El Caballo de Bronce. La estatua de Felipe IV. Arte y técnica al servicio de la Monarquía, Madrid: Real Academia de Bellas Artes de San Fernando 1997; Zikas, Dimitrios: „Ars sine scientia nihil est“. Il contribuito di Pietro Tacca al bronzo italiano“. In Falletti, Franca (ed.): Pietro Tacca. Carrara, la Toscana, le grandi corti europee, Ausstellungskatalog Carrara, Firenze: Mandragona 2007, pp. 54-73; Bodart, Diane H.: Pouvoirs du portrait sous les Habsbourg d'Espagne, Paris: CTHS/ INHA 2011, pp. 414-418.

9. Zum Überblick über beide Gattungen bzw. Einflüsse zwischen den Medien siehe: Liedtke: Royal Horse; Larsson, Lars Olof: Antonio Tempesta und das Reiterporträt im 17. Jahrhundert eine typologische Studie. In Wege nach Süden. Wege nach Norden. Aufsätze zu Kunst und Architektur. Als Festgabe zum 60. Geburtstag hg.von Adrian von Buttlar, Ulrich Kuder und Hans-Dieter Nägelke. Kiel: Ludwig 1998, pp. 26-35.

10. Zum spanischen Reiterporträt siehe u.a.: Liedtke, Walter A./ Moffitt, John F.: Velázquez, Olivares, and the baroque equestrian portrait. The Burlington Magazine CXXIII (1981), no. 942, pp. 528-537; Moffitt, John F.: Velazquez y el significado del retrato ecuestre barocco. Goya 202 (1988), pp. 207-215; Miguel Morán Turina: «Pues es más que Alexandro y tu si Apeles». Notas sobre los retratos ecuestres de Velázquez. In: El Palacio del Buen Retiro y el nuevo museo del Prado. Madrid (2000), pp. 63-87; Mínguez, Víctor: La invención de Carlos II. Apoteosis simbólica de la casa de Austria. Madrid: CEEH 2013, 193-216 („El rey cabalga y gobierna“).

11. Einen kleinen Überblick über Reiterstatuen bzw. Statuetten der Höfe in Madrid, Wien und Paris bietet: Sáenz de Miera, Jesús: Sobre los generos artisticos y la representación del poder. In: Checa Cremades, Fernando (ed.): Cortes del Barroco. De Bernini y Velázquez a Luca Giordano. Ausstellungskatalog Madrid/ Aranjuez. Madrid: SEACEX 2003, pp. 216-223. Eine erste Fassung dieses Beitrages bildet: Friedrich Polleroß: „Theatro della Gloria Austriaca“. Das Reiterporträt als Herrschaftszeichen der Casa de Austria. In: Alexandra Merle, Éric Leroy du Cardonnoy (eds.), Les Habsbourg en Europe. Circulations, échanges, regards croisés (= Studia Habsburgica1; Reims 2018) pp. 79-92, fig. 1-29.

12. Siehe das Kapitel „Rubens, Velázquez, and the Spanish Riding School“ in: Liedtke: Royal Horse, pp. 18-35; van Babel/ Basche/ Gürtler: Hofreitschule.

13. Liedtke: Royal Horse, pp. 192-193; Leesberg, Marjolein/ Leeflang, Huigen: Johannes Stradanus. Part III (The New Hollstein. Dutch \& Flemish etchings, engravings and woodcuts 1450-1750). Amsterdam: Sound \& Vision Publishers 2008, pp. 232-277, cat.-nr. 527-566. Auf die möglichen Einflüsse dieser Stiche auf Velázquez wurde schon hingewiesen: De Cavi, Sabina: Nuove fonti per l'iconografia equestre del Salón de los Reinos di Velázquez al Buen Retiro (1628-1634/35). Locvs amoenvs 11 (2011/12), pp. 129-149, hier 136-137. 
Cano zeigen Philipp IV. und vor allem seinen Sohn Baltasar Carlos in der Reitschule explizit bei der sogenannten corveta oder levade, einer besonders schwierigen Aufgabe der Reitkunst, da dabei das steigende Pferd mit nur einer Hand geleitet werden durfte ${ }^{14}$. Die antike Metapher, derzufolge ein guter Herrscher sein Volk ebenso wie sein Pferd zu lenken versteht, wurde u.a. 1623 vom Juristen Jéronimo de Cevellos in seinem Traktat Arte real para del buen govierno de los Reyes, y Principes, y de sus vasallos expressis verbis unter Bezugnahme auf Valerius Maximus formuliert: „El reynar, señor, es como domar un cavallo desbocado, y feroz' que sino se rige con prudencia, y arte, derribarà al que subiere en el. ,Qui regnum adipiscitur simile est ei, qui equm habet indomitum, à quo nisi cum arte et perittà noverit, tergo eius insidere.' (Val. Max. lib. 7)“15, Als Ausgangspunkt in künstlerischer und ideologischer Hinsicht bietet sich Tizians Gemälde von Kaiser Karl V. in der Schlacht bei Mühlberg von $1548 \mathrm{an}^{16}$ (Abb. 4). Auch wenn es vielfältige ikonographische Interpretationen vom Miles Christi bis zur Profectio Augusti und von Caesar bis Konstantin zulässt oder - vielleicht besser gesagt - bewusst verbindet ${ }^{17}$, steht der Typus in der Tradition des Reiterdenkmals von Marc Aurel auf dem Kapitol, das lange Zeit als ein Monument des ersten christlichen Kaisers Konstantin galt. Das Gemälde diente der Erinnerung an den kaiserlichen Sieg über die protestantische Liga von Schmalkalden. Der Herrscher erscheint daher nicht nur mit der während der Schlacht am 24. April 1547 getragenen Rüstung ${ }^{18}$, sondern auch mit der purpurroten Schärpe der Katholiken. Die Rolle Karls V. als Verteidiger des katholischen Glaubens hätte nach Meinung von Pietro Aretino noch deutlicher visualisiert werden sollen. Der Dichter schlug nämlich vor, über dem Herrscher die Personifikationen der Religion mit Kelch und Kreuz sowie des Ruhmes mit Trompete und Weltkugel zu malen: „la Religione e la Fama, l'uno con la croce e il calice in mano, che gli mostrasse il cielo, e l'altra con le ali e le trombe, che gli offerisse il mondo" ${ }^{\text {"19. }}$.

14. Warnke, Martin: Das Reiterbildnis des Baltasar Carlos von Velázquez. In: Badt, Kurt/ Gosebruch, Martin (eds.): Amici amico. München: Fink Verlag 1968, pp. 217-227; Carr, Dawson W.: Painting and Reality: The Art and Life of Velázquez. In derselbe (ed.). Velázquez, Ausstellungskatalog National Gallery. London: Yale University Press 2006, pp. 26-53, 38 und 76-179, cat.-nr. 25 und 182-185, cat.-nr. 27.

15. De Cevallos, Jéronimo: Arte real para del buen govierno de los Reyes, y Principes, y de sus vasallos. Toledo: Eigenverlag 1623, fol. 96r.

16. Checa, Fernando: Tiziano y la monarquia hispanica. Usos y funciones de la pintura veneciana en España (siglos XVI y XVII). Madrid: Nerea 1994, pp. 35-51; Bodart: Pouvoirs du portrait, pp. 255-260.

17. Oberhaidacher, Jörg: Zu Tizians Reiterbildnis Karls V. Eine Untersuchung seiner Beziehungen zum Georgsthema. In: Jahrbuch der kunsthistorischen Sammlungen in Wien 78 (1982), 69-90; Moffitt, John F.: The Forgotten Role of a „Determined Christian Knight“ in Titian's Depiction of ,Charles V, Equestrian, at Mühlberg. In: Gazette des Beaux Arts 137 (2001), 37-52.

18. Soler del Campo, Álvaro (Hg.): El arte del poder. La Real Armería y el retrato del corte, Ausstellungskatalog. Madrid: SEACEX 2010, 138-141, Kat.-Nr. 15 und 16.

19. Brief Nr. CDXII vom April 1548: Fidenzio Fertile (Hg.): Lettere sull'arte di Pietro Aretino, 2. Bd. (1543-1555). Milano: Edizioni del Milione 1957, 212; Wethey, Harold E.: The Paintings of Titian. II. The Portraits. London: Phaidon 1971, pp. 87-90, nr. 21; Checa: Tiziano, p. 42. 
Dass der Typus in habsburgischem Kontext sowohl ein spanisches als auch ein imperiales Image verkörperte, lässt sich an einigen Druckgraphiken belegen. Als der Venezianer Domenico de Franceschi um 1555 eine „vera effigie“ des Kronprinzen Philipp II. von Spanien schuf, wurde der „filio di Carlo Quinto Imperatore" nicht nur zu Pferde, sondern auch mit dem Doppeladler als Zeichen der kaiserlichen Abstammung porträtiert ${ }^{20}$.

Den Gedanken einer ,form follows function' aufgreifend entstand 1604 in der Reichsstadt Köln die Bildfolge „Romani Imperatores Domo Austriae editi X hoch tempore postremi“ des niederländischen Kupferstechers Crijspin de Passe. Sie bildete ein Gegenstück bzw. eine Fortsetzung zu einer wenige Jahre vorher vom selben Künstler geschaffenen Kupferstichfolge der Zwölf Römischen Kaiser. Der Bezug zu den antiken Anfängen des Reiches wurde von de Passe bei den Habsburgerbildnissen jedoch auch in ikonographischer Form hergestellt, da die zehn Herrscher nicht nur als Reiter, sondern teilweise all'antica mit Lorbeerkränzen und römischen Rüstungen oder antikisierenden Bauten im Hintergrund dargestellt wurden. So bildet das Porträt von Albrecht I. von Habsburg eine Variante eines älteren Vespasianstiches und jenes von Albrecht II. eine Paraphrase einer Graphik des Tiberius in der Kaiserserie von Antonio Tempesta. Das Titelblatt kopierte das Titelkupfer für die Serie Römischer Kaiser von Hendrik Goltzius aus dem Jahre 1586, die ebenfalls schon Rudolf II. gewidmet war, ersetzte aber die Personifikation der Roma durch den Doppeladler ${ }^{21}$. Tatsächlich hatte de Passe seit 1594 mehrfach Bildnisse Rudolfs II. gestochen und auch dessen Porträt der Kaiserserie nach dem bekannten Reiterporträt des Habsburgers von Ägydius Sadeler nach Adriaen de Vries kopiert ${ }^{22}$. Ebenso wie zahlreiche Allegorien in Form von Bronzereliefs von Adriaen de Vries sowie als Gemälde von Bartholomäus Spranger und Hans von Aachen ${ }^{23}$ sollte auch das von Rudolfs Hofkupferstecher angefertigte großformatige Reiterporträt des Kaisers auf Rudolfs vemeintliche Siege über die Türken hinweisen, wobei der ungewöhnli-

20. Polleroß: Reiterporträt, Taf. XIV.

21. Boon, K.G./Verbeek, J.: Van Ostade - De Passe ( Hollstein XV), Amsterdam: Hertzberger o.J., pp. 217-218, cat.-nr. 655-666; Pelc, Milan: Illustrium Imagines. Das Porträtbuch der Renaissance (Studies in Medieval and Reformation Thought LXXXVIII). Leiden/ Boston/ Köln: Brill 2002, p. 105 und cat.-nr. 122.

22. Veldman, Ilija: Crispijn de Passe’s Representations of Emperor Rudolf II. In: Konečný, Lubomír/ Slaviček, Lubomir (eds.). Libellus Amicorum Beket Bukovinská. Praha: Artefactum 2013, pp. 136-155, hier 136-155.

23. Vocelka, Karl: Die politische Propaganda Kaiser Rudolfs II. (1576-1612) Viena: ÖAW 1981, pp. 219 299 („Die Zeit des Langen Türkenkrieges“); Prag um 1600. Kunst und Kultur am Hofe Kaiser Rudolfs II. Ausstellungskatalog Wien, 1. Bd. Freren: Lucas Verlag 1988, 1. Band cat.-nr. 58, 87, 102-104,163, 182-183, 2. Band, cat.-nr. 548-550 und 676; Praga magica 1600, Ausstellungskatalog Dijon, Paris 2002, cat.-nr. 29; Reichl-Ham, Claudia: Der „Lange Türkenkrieg“ Rudolfs II. und seine Rezeption im Heeresgeschichtlichen Museum. In: Viribus Unitis. Jahresbericht 2007 des Heeresgeschichtlichen Museums. Wien 2008, pp.1134 , hier $7-22$. 
che Speer direkt auf das Reiterporträt Karls V. Bezug nahm ${ }^{24}$ (Abb. 5). Diese Graphik und vor allem das 63 Zentimeter hohe Reitermonument Rudolfs II. von Giambologna (um 1595) ${ }^{25}$ beweisen, dass der Habsburger diese Ikonographie als Zeichen seiner kaiserlichen Würde betrachtet hat und in den für ihn charakteristischen Medien der Druckgraphik und Kunstkammerstücke künstlerisch umsetzen ließ. ${ }^{26}$

Doch das Reiterporträt (mit steigendem Pferd) besaß nicht nur eine spanische und eine römische Wurzel, sondern - wie oben erwähnt - auch eine explizit habsburgisch-kaiserliche Tradition, nämlich das 1555 im Ehrenspiegel des Hauses Österreich abgebildete Denkmal für König Rudolf I. in Straßburg (Abb. 1). Eine Abschrift dieser Handschrift befand sich auch im Besitz von Kaiser Rudolf II. sowie seiner Erben, und daher war es vermutlich kein Zufall, dass der ,rudolfinische Typus' des Reiterporträts sowohl für Kaiser Ferdinand II. als auch für dessen Sohn explizit übernommen wurde. So schuf Lucas Kilian nach dem habsburgischen Erfolg gegen die Protestanten in der Schlacht bei Nördlingen im Jahre 1634 einen ebenfalls großformatigen Kupferstich des Römischen Königs, der eine direkte Paraphrase des grafischen Porträts von Rudolf II. darstellt ${ }^{27}$ (Abb. 6).

Doch Ferdinand III. griff auch die zweite Idee seines Vorgängers auf, nämlich die Repräsentation der kaiserlichen Majestät in Form von Reiterstatuetten in der Kunstkammer ${ }^{28}$. Waren die Zimmermonumente von Kaiser Rudolf II., Erzherzog Maximilian III. und Erzherzog Leopold V. noch Einzelstücke gewesen ${ }^{29}$, so übernahm Ferdinand III. bald nach seinem Regierungsantritt als Kaiser im Zuge einer repräsentativen Neugestaltung und Aufwertung der kaiserlichen Schatzkammer Rudolfs Idee der Kunstkammermonumente und begründete damit eine $\mathrm{Serie}^{30}$. Um 1640 wurden nämlich bei Caspar Gras

24. Volrábová, Alena/ Kubíková, Blanka (eds.): Rudolf II. a mistři graficke'ho umĕní/ Rudolf II and Masters of Printmaking, Ausstellungskatalog Praha: Národní Galerie v Praze 2012, pp. 20-21, cat.-nr. $1 / 3$.

25. Prag um 1600, p. 139, cat.-nr. 46 (Lars Olof Larsson).

26. Leuschner, Eckhard: Roman Virtue, Dynastic Succession and the Re-Use of Images: Constructing Authority in Sixteenth- and Seventenneth-Century Portraiture. In: Studia Rudolphina 6 (2006), pp. 5-25, 19-21; Polleroß, Friedrich: „Kayserliche Schatz- und Kunstkammer“. Die habsburgischen Sammlungen und ihre Öffentlichkeit im 17. Jahrhundert. In: Haag, Sabine / Kirchweger, Franz/ Rainer, Paulus (eds.): Das Haus Habsburg und die Welt der fürstlichen Kunstkammern im 16. und 17. Jahrhundert (Schriften des Kunsthistorischen Museums 15). Wien: Holzhausen 2016, pp. 255-295, hier 255-262.

27. Dethlefs, Gerd. WFLM Münster: Das Kunstwerk des Monats. Mai 2016, Münster 2016: http:// www.lwl.org/landesmuseum-download/kdm/archiv/2016/Ans_KdM_Mai_2016.pdf.

28. Zur Vorbildwirkung der Druckgraphiken u.a. auf Velázquez' Reiterporträts siehe: Larsson: Reiterporträt, pp. 26-31.

29. Zur Reiterstatuette des Erzherzog Maximilian III. von Hubert Gerhard um 1600/05 siehe: Ammann, Gert (ed.): Ruhm und Sinnlichkeit. Innsbrucker Bronzeguss 1500-1650 von Kaiser Maximilian I. bis Erzherzog Ferdinand Karl, Ausstellungskatalog. Innsbruck: Tiroler Landesmuseum 1996, pp. $242-$ 244 (Manfred Leithe-Jasper).

30. So wurden offensichtlich auch die Büsten Karls V. von Leone Leoni und Rudolfs II. von Adriaen de Vries um die Bronzebüste Ferdinands III. von Schweiger ergänzt: Polleroß: Kunstkammer, p. 268. 
offensichtlich gleichzeitig die metallenen Reiterstatuetten von Ferdinand II. und Ferdinand III. in Auftrag gegeben, denen später jene von Erzherzog Sigmund Franz, Erzherzog Ferdinand Karl und Leopold I. folgten ${ }^{31}$. Das von den Kaiserserien der Jahre $1580^{32}$ und 1604 vorgegebene Prinzip der Reiterporträtfolge wurde damit offensichtlich bewusst auf die Gattung der Kunstkammermonumente übertragen (Abb. 7). Da jedoch nicht nur die verwandtschaftlichen, sondern auch die kunstpolitischen Verbindungen zwischen Ferdinand III. und seinem Cousin, Schwager und Schwiegervater Philipp IV. von Spanien eng waren ${ }^{33}$, könnte die Idee zur Anfertigung einer Wiener Familienserie von Reiterporträts allerdings auch von Madrid inspiriert oder vielleicht sogar von beiden Linien parallel bzw. in mehreren Schritten gemeinsam entwickelt worden sein. Tatsächlich war schon um 1615-20 eine Reiterstatuette Philipps IV. als Kronprinz aus vergoldeter Bronze entstanden, die Pietro Tacca zugeschrieben wird. Ob es sich dabei um einen Entwurf für ein zweites Standbild in Madrid oder ,nur' um ein diplomatisches Geschenk und Kunstkammerstück handelt, ist allerdings ebenso wenig bekannt wie der ursprüngliche Besitzer des erst 1952 vom Prado angekauften Kunstwerkes ${ }^{34}$.

Davon abgesehen wurde nach dem Umbau des Alcázar in Madrid der Salón Nuevo, der später als Salón de los Espejos bekannt gewordene repräsentativste Raum der spanischen Königsresidenz, um 1625 zunächst u.a. mit dem Reiterporträt von Karl V. in der Schlacht bei Mühlberg, der Allegorie von Philipp II., der den Thonfolger nach der Schlacht von Lepanto Gott darbringt, sowie dem Gemälde Spanien hilft dem Glauben, also einer Allegorie der Gegenreformation, von Tizian geschmückt ${ }^{35}$. Dazu kamen das Reiterporträt Philipps IV. von Velázquez sowie dessen Gemälde Philipp III. und die Vertreibung der Mauren ${ }^{36}$. Der spanische König wurde auf dem Porträt vermutlich nicht nur mit dem von seinem Urgroßvater geerbten Prognatismus porträtiert, sondern auch - wie aus einem Brief des päpstlichen Nuntius

31. Ammann, Ruhm und Sinnlichkeit, pp. 300-317.

32. Vitásek, Gabriele: Das EFFIGIERVM CAESARVM OPVS, eine illuminierte Kaiserreihe von 1580. Frühneuzeit-Info 11 (2000) Heft 2, pp. 28-49.

33. Polleroß, Friedrich: Serie, Paraphrase, Kopie: Diego Velázquez und Frans Luycx als Porträtisten der Casa de Austria. In: Sylvia Ferino-Pagden (Hg.), Velázquez: Anregungen, Vorschläge, Lösungen (= Schriften des Kunsthistorischen Museums 18, Wien 2018), pp. 142-165.

34. Azcue Brea, Leticia: Panorama de la escultura cortesana y el coleccionismo escultórico nobiliario en la época de Felipe IV. Estado de la cuestión. In: José Martínez Millán/ Manuel Rivero Rodríguez (Hg.): Arte, coleccionismo y sitios reales (La corte de Felipe IV (1621-1665): Reconfiguración de la Monarquía católica III/4). Madrid: Ediciones Polifemo 2017, pp. 2871-3001, hier 2967-2971, fig. 10.

35. Zu den Gemälden Tizians siehe: Checa: Tiziano, pp. 36-87.

36. Orso, Steven N.: Philip IV and the Decoration oft he Alcázar of Madrid. Princeton NJ: Princeton University Press 1986, pp. 43-60; Checa, Fernando (ed.): El Real Alcázar de Madrid. Dos siglos de arquitectura y coleccionismo en la corte de los Reyes de España, Ausstellungskatalog. Madrid: Nerea 1994, p. 391. 
vom 16. Juni 1625 hervorgeht - „como un César“37. Leider erfahren wir aus dem Schreiben an den Vatikan nicht, ob sich diese Aussage auf die Gegenüberstellung zu Karl V., auf den Typus des steigenden Pferdes oder auf eine Rüstung all'antica bezog.

Das Bildnis des regierenden Monarchen wurde jedoch bereits 1628 durch das nur in Kopie überlieferte Reiterporträt Philipps IV. als globaler Verteidiger des katholischen Glaubens von Peter Paul Rubens ersetzt, der mit den Personifikation der göttlichen Gerechtigkeit („la divina Justicia“) bzw. des göttlichen Zorns („furor divino“), des Glaubens sowie der die Häresie symbolisierenden Schlange und der Darstellung des Globus die barocke Allegorie in das spanische Königsporträt einführte (Abb. 8) ${ }^{38}$. Unbewusst oder beabsichtigt wurde damit offensichtlich die ikonographische Idee Aretinos für das Bildnis Karls V. aufgegriffen ${ }^{39}$. Und es war wohl auch der flämische Meister, der um 1625 mit der Medici-Galerie in Paris eine barocke Inkunabel eines politischen ,Gesamtkunstwerkes ${ }^{40}$ und mit der Teppichfolge Triumph der Eucharistie eine Verherrlichung von Kaiser Ferdinand II. und von König Philipp IV. als Verteidiger des katholischen Glaubens im Dreißigjährigen Krieg ${ }^{41}$ geschaffen hatte, der vielleicht erst nach seiner Rückkehr nach Antwerpen eine neue Idee ins Spiel brachte; nämlich nicht nur das Port-

37. Baticle, Jeannine: El retrato ecuestre del rey Felipe IV. In: Alpers, Svetlana e.a. Velázquez. Barcelona: Galaxia Gutenberg 1999, pp. 57-69, hier 62.

38. Huemer, Frances: Portraits I (Corpus Rubenianum Ludwig Burchard XIX), Brussels: Arcade 1977, pp. 150-154, cat.-nr. 30; Ligo, Larry L.: Two Seventeenth-century Poems wich link Rubens ' Equestrian Portrait of Philip IV to Titian's Equestrian Portrait of Charles V. In: Gazette des Beaux-Arts 112 (1970), pp. 345-354; Volk, Mary Crawford: Rubens in Madrid and the decoration of the Salón Nuevo in the Palace. The Burlington Magazine CXXII (1980), no. 924, 168-180; Vergara, Alejandro: Rubens and His Spanish Patrons, Cambridge/ New York/ Melbourne: Cambridge University Press 1999, pp. 67-75; Llombart Garín, Felipe V./ Salort Pons, Salvador (eds.): Velázquez, Ausstellungskatalog Roma, Milano: Electa 2001, pp. 232-237; Rey, José López-Rey/ Delenda, Odile: Velázquez. Das vollständige Werk, Köln: Taschen 2014, p. 374, cat.-nr. 96; Haag, Sabine (ed.): Velázquez, Ausstellungskatalog Wien, München: Hirmer 2014, cat.nr. 24 (Javier Portús Pérez); Jacquot, Dominique: Rubens. Portraits princiers, Ausstellungskatalog. Paris: Éditions de la Réunion des musées nationaux 2017, pp. 126-127, cat.-nr. 21.

39. Einen ähnlichen Gedanken hat Falomir Faus bereits 2001 geäußert: Falomir Faus, Miguel: Tiziano, el Aretino y las „alas de la hipérbole“. Adulación y alegoría en el retrato de los siglos XVI y XVII. In: La Restauración de „El emperador Carlos V a caballo en Mühlberg“ de Tiziano, Ausstellungskatalog. Madrid: Museo Nacional del Prado 2001, pp. 71-86, hier 74-80.

40. Wehlen, Bernhard. „Antrieb und Entschluss zu dem was geschieht“. Studien zur Medici-Galerie von Peter Paul Rubens (Beiträge zur Kunstwissenschaft 86). München: Scanneg 2008; Van Hout, Nico. ,Henry IV valait bien une Galerie!' Rubens‘ unvollendetes Projekt für das Palais du Luxembourg. In: Finckh, Gerhard, Hartje-Grave, Nicole (eds.). Peter Paul Rubens. Wuppertal: Van der Heydt-Museum 2012, pp. 88-115; Mückain, Olaf. Zwei Gemäldezyklen für den französischen Hof. In: ebenda, pp. 268-293. Auf mögliche Bezüge zwischen Rubens' Galerie in Paris und seinen Gemälden in Madrid hat erstmals Ulrich Pfisterer hingewiesen: Pfisterer, Salón de Reinos, pp. 210-211. Auf mögliche Bezüge zwischen Rubens Galerie in Paris und seinen Gemälden in Madrid hat erstmals Ulrich Pfisterer hingewiesen: Pfisterer, Ulrich. Malerei als Herrschafts-Metapher. Velázquez und das Bildprogramm des Salón de Reinos. Marburger Jahrbuch für Kunstwissenschaft 29 (2002), pp. 199-252, hier 210-211.

41. Brassat, Wolfgang. Für die Einheit der katholischen Liga. Zum politischen Gehalt des EucharistieZyklus von Peter Paul Rubens. Idea. Jahrbuch der Hamburger Kunsthalle VII (1988), pp. 43-62; LiskenPruss, Marion. Rubens im Dienst des Brüsseler Hofes. In: Finck, Hartje-Grave, Rubens, pp. 176-203; Woollett, Anne T. Faitt and Glory. The Infanta Isabel Clara Eugenia and the ,Triumph of the Eucharist‘. 
rät Philipps IV. auszutauschen, sondern auch das von Rubens nach der Darstellung Karls V. in der Tunistapisserie von Jan Cornelis Vermeyen kopierte Reiterporträt Philipps II. in der Schlacht von St. Quentin ${ }^{42}$ an die Stelle der ,königlichen Darbringung 'Tizians zu hängen und nach 1634 mit einem weiteren Reiterporträt des Kardinalinfanten Don Ferdinand als Sieger über die Protestanten ${ }^{43}$ (Abb. 9) die vier Ecken des galerieartigen Raumes künstlerisch und inhaltlich aufeinander abzustimmen oder die Serie zumindest ikonographisch-ideologisch fortzusetzen ${ }^{44}$.

Auf einem Gemälde der Genter Festlichkeiten zur Feier des Triumphes von 1634 porträtierte Cornelis Schut ebenso wie sein Lehrer Rubens in Antwerpen ${ }^{45}$ den spanischen und den österreichischen Ferdinand auf dem Pferd als gemeinsame Sieger der Schlacht bei Nördlingen ${ }^{46}$ (Abb. 10). Die Vision der Gottesmutter mit dem segnenden Christkind resultiert aus der Tatsache, dass die Habsburger Maria damals zur Generalissima ihrer Heere erklärt hatten ${ }^{47}$, und bezeugt, dass das triumphale Reiterporträt also eindeutig den mit göttlicher Hilfe erlangten militärischen Erfolg der Casa de Austria über die ,ungläubigen' Protestanten und Muslime visualisierte. In diesem Zusammenhang ist auch auf die Darstellungen des Santiago Matamoros zu verweisen, der im 17. Jahrhundert auf steigendem Pferd zur „Symbolfigur für den Kampf gegen Ketzer- und Heidentum" wurde. ${ }^{48}$ Wenngleich die Vermutung einer Rubens'schen Serie für den Salón de Espejos spekulativ ist, so wird das dahinter stehende politisch-pädagogische Konzept auch durch ein

In Vergara, Alejandro, Woollett, Anne T. (eds). Spectacular Rubens. The Triumph of the Eucharist. Los Angeles: The J. Paul Getty Museum 2014, pp. 10-29.

42. Das erst 1686 im Inventar des Alcázar aufscheinende Gemälde wird zwischen 1629 und 1640 datiert: Falomir Faus: Tiziano, p. 74 und 84; García-Frías Checa/ Jordán de Urríes y del Colina: El Retrato, pp. 212-216, cat.-nr. 54; Bodart: Pouvoirs du portrait, pp. 260-263.

43. Brown: Velázquez, Rubens y Van Dyck, pp. 136-139, cat.-nr. 8.

44. Einen ähnlichen Gedanken hat Falomir Faus bereits 2001 geäußert: Falomir Faus, Miguel: Tiziano, el Aretino y las „alas de la hipérbole“. Adulación y alegoría en el retrato de los siglos XVI y XVII. In: La Restauración de „El emperador Carlos V a caballo en Mühlberg“ de Tiziano, Ausstellungskatalog. Madrid: Museo Nacional del Prado 2001, pp. 71-86, hier 83-86; Vgl. dazu auch: Vergara, Alejandro. El universo cortesano de Rubens. In Brown, Velázquez, Rubens y Van Dyck, pp. 67-89, hier 83-85; Heinen, Ulrich. Loyalität - Diplomatie - Religion. Peter Paul Rubens` Beitrag zum Überleben der Habsburgischen Niederlande. In Finckh, Gerhard/ Hartje-Grave, Nicole (eds.). Freiheit - Macht - Pracht. Niederländische Kunst im 17. Jahrhundert. Ausstellungskatalog Wuppertal: Von der Heydt-Museum 2009, pp. 10-31.

45. Martin, John Rupert. The Decoration of the Pompa Introitus Ferdinandi (Corpus Rubenianum Ludwig Burchard XVI), Brussels: Arcade 1972, pp. 147-150, cat.-nr. 37.

46. Zum Gemälde: Liedtke: Royal Horse, p. 266, nr. 138; Wilmers, Gertrude, Cornelis Schut (1597-1655). A Flemish Painter of the High Baroque (Pictura Nova I), Turnhout: Brepols 1996, pp. 8385, cat.-nr. 22; Walgrave, Jan. A Royal Image. The Image of the Sovereign since Sir Anthony Van Dyck, Ausstellungskatalog Antwerpen: Provincie Antwerpen 1999, pp. 131-132, cat.-nr. 34.

47. Coreth, Anna. Pietas Austriaca. Österreichische Frömmigkeit im Barock. Wien: Oldenbourg Wissenschaftsverlag 2. Auflage 1982, pp. 45-72.

48. Scholz-Hänsel, Michael. Bildpropaganda gegen die Anderen. Spanische Kunst im europäischen Kontext der Toleranzdiskussion des Westfälischen Friedens. In: Bußmann, Klaus/ Schilling, Heinz (ed.). 1648. Krieg und Frieden in Europa. 2. Bd. Münster/ Osnabrück: 1998350 Jahre Westfälischer Friede mbH 1998, pp. 131-139, 133, Abb. 1. 
Gemälde des Rubensschülers Gaspar de Crayer verdeutlicht, das 1634 nach der Schlacht von Nördlingen für einen Triumphbogen zu Ehren von Kardinalinfant Ferdinand in Gent entstanden ist. Auf dieser Darstellung treffen der spanische Feldherr und sein Ururgroßvater zu Pferd sowie mit dem Marschallstab gleichsam in einer genealogischen Vision auf dem Schlachtfeld zusammen ${ }^{49}$ (Abb. 11) und Karl V. instruiert seinen Nachkommen ${ }^{50}$, wie die Inschrift des danach angefertigten Kupferstiches verrät: DISCE NEPOS VIRTVTEM EX ME (Lerne Enkel von mir die Tugend!). Tatsächlich war die Vorstellung, dass Herrscher aus der Geschichte und von Vorbildern lernen sollten, Philipp IV. von seiner eigenen Erziehung her geläufig und der Salón de los Espejos war eindeutig nicht nur eine Gemäldegalerie, sondern auch „a Hall of Princely Virtue" und insbesondere eine Ruhmeshalle der katholischen Könige $^{51}$. In diesem Zusammenhang scheint es mir wahrscheinlich, dass die namengeben acht Spiegel des Saales mit ihren Adlerrahmen aus vergoldeter Bronze nicht nur luxuriöse Dekoration, sondern symbolisch als Tugendspiegel zu deuten sind und damit zentraler Teil des Konzeptes waren. Eine solche Interpretation erlaubt vor allem das 1655 in Brüssel veröffentliche Titelkupfer des Rubensenkelschülers Erasmus Quellinus d.J. zum Speculum Principum von Petrus Belluga, das einen (habsburgischen) Herrscher zeigt, dem die Allegorie des Glaubens und der Eintracht oder Gerechtigkeit den Spiegel vorhalten, in dem er von den Personifikationen der Tugenden umgeben erscheint ${ }^{52}$ (Abb. 12). Die zentrale künstlerisch-allegorische Bedeutung, die dem Spiegel im Gruppenporträt Las Meninas von Velázquez zukommt ${ }^{53}$, lässt eine solche Vermutung ebenso naheliegend erscheinen wie die Interpretation der im Folgenden zu behandelnden Gemälde des Salón de Reinos als „un verdadero ,speculum principum“, wie es auch in mehreren Darstellungen des Thronfolgers Karl II visualisiert wurde ${ }^{54}$. Die Raumausstattung folgte also offensichtlich dem Muster der Karl V. würdigenden Galerie sowie

49. Zum Gemälde: Liedtke: Royal Horse, p. 268, nr. 140; Vlieghe, Hans. Gaspar de Crayer, sa vie es ses oeuvres (Monographie du „Nationaal Centrum voor de plastische kunsten van de XVIde en XVIIde eeuw“ IV). Bruxelles: Arcade 1972, pp. 120-121, fig. 50; Van de Velde, Carl, Vlieghe, Hans. Stadsversieringen te Gent in 1635 voor de blijde intrede van den Kardinaal-Infant. Gent: Stadt Gent 1969, pp. 51-53, ill. 39-40.

50. Diese Thematik wurde schon 1622 bei einem Kupferstich von Pedro Perret aufgegriffen, der den Infanten Don Carlos vor einem Bildnis Karl V. zeigt, dessen Rahmen die Aufschrift trägt: VIRTVTEM EX ME: El linaje del Emperador, Ausstellungskatalog Cáceres: Centro de Exposiciones San Jorge 2000, pp. 378-379, cat.-nr. 8.7.

51. Orso: Alcázar, pp. 89-95.

52. Diels, Ann. The Shadow of Rubens. Print Publishing in 17th-century Antwerp. Prints by the history painters Anselm van Diepenbeeck, Cornelis Schut and Erasmus Quellinus II, London/ Turnhout Harvey Miller Publishers/ Brepols 2009, ill. 38. Das Thema wurde später auf eine Allegorie für Leopold I. übertragen.

53. Ameling Emmens, Jan. ,Las Meninas‘ von Velázquez: Fürstenspiegel für Philipp IV. In Greub, Thierry (ed.). Las Meninas im Spiegel der Deutungen. Berlin: Dietrich Reimer Verlag 2001, pp. 115-133; Pippal, Martina: „Las Meninas“ von Diego Velázquez - des Rätsels Lösung? In: Ferino, Velázquez, pp. 166-195, hier 185.

54. Mínguez: Carlos II, pp. 65-72. 
der zu Ehren Philipps III. im Pardo Palast eingerichteten Galería de Doce Virtudes ${ }^{55}$.

Es war jedenfalls nur folgerichtig, dass genau in den Jahren um 1634/35 das im Alcázar begonnene Konzept der seriellen Reiterporträts auch bei der Ausstattung im Thronsaal des Buen Retiro Palastes aufgegriffen und aktualisiert wurde. Damals hat man die offensichtlich zunächst für die Stadtresidenz vorgesehenen großformatigen Gemälde von Philipp III. und Margarethe von Österreich durch Leinwandstreifen vergrößert und gemeinsam mit den ebenfalls von Velázquez und seiner Werkstatt stammenden Bildnissen von Philipp IV. und Isabella von Bourbon an den Schmalwänden des Salón de Reinos installiert ${ }^{56}$ (Abb. 13-14). Gleichzeitig wurden die vier Reiterporträts mit dem kleineren Reiterbildnis des Thronfolgers Baltasar Carlos (Abb. 15) sowie mit einem Zyklus spanischer Könige, mit den Wappen der 24 Reiche, mit einer Serie zeitgenössischer, vorwiegend gegen die kalvinistischen Holländer geführter Schlachten und mit einer Folge der Arbeiten des Herkules ergänzt und ideologisch eingebunden ${ }^{57}$, um - wie es der Hofdichter José Pellicer de Tovar 1635 in einem Sonett auf das Reiterporträt des Baltasar Carlos ausführte - den Betrachter „zu noch größeren Ruhmestaten anzufeuern ${ }^{\text {"58 }}$. Alle diese thematischen Bezüge laufen in der Person des zwischen den Bildnissen seiner Eltern thronenden Königs bzw. im Reiterporträt des Thronfolgers inmitten der Porträts seiner Eltern auf der gegenüberliegenden Schmalwand des Saales zusammen, wie der portugiesische Dichter

55. Kagan, Richard L. Imágines y política en la corte de Felipe IV de España. Nuevas perspectiva sobre el Salón de Reinos. In Palos, Joan Lluís/ Carrió-Invernizzi, Diana (eds.). La historia imaginada. Madrid: CEEH 2008, pp. 101-119, hier 106-107.

56. Portús, Javier/ J. García-Máiquez/ R. Dávila: Los retratos ecuestres de Felipe III y Margarita de Austria de Velázquez para el Salón de Reinos. In: Boletín del Museo del Prado XXIX (2011) Nr. 47, pp. 16-39.

57. Moffitt, John F. An ,Emblematization` of Philip IV in the ,Salón de Reinos‘. Pantheon XLVIII (1990), pp. 70-75; Luna Fernández, Juan José. „Der Salón de Reinos des Buen Retiro-Palastes in Madrid“. In Bußmann, Klaus/ Schilling, Heinz (eds.). 1648. Krieg und Frieden in Europa, Kunst und Kultur. Ausstellungskatalog Münster/ Osnabrück 2. Textband. München: Bruckmann 1998,, pp. 121-129; Brown, Velázquez, pp. 107-129, 121-129; Brown, Jonathan (ed.). Velázquez, Rubens y Van Dyck. Madrid: Ediciones el viso 1999, pp. 136-139, cat.-nr. 8, 107-129; Brown, Joanthan: The Hall of Realms and the Thirty Years‘ War. In: Ronald G. Asch/ Wulf Eckart Voß/ Martin Wrede (Hg.): Frieden und Krieg in der Frühen Neuzeit. Die europäische Staatenordnung und die außereuropäische Welt. München: Wilhelm Fink Verlag 2001, pp. 207-214; Brown, Jonathan/ Elliott, John H. A Palace for a King. The Buen Retiro and the Court of Philip IV, New Haven/ London: Yale University Press 1. Auflage 1980, 2. Auflage 2003, pp. 141-202; Álvarez Lopera, José: The Hall of Realms: the Present State of Knowledge and a Reconsideration. In: Úbeda de los Cobos, Andrés (ed.). Painting for the Planet King. Philip IV and the Buen Retiro Palace, Ausstellungskatalog Madrid, London: Paul Holberton Publishing 2005, pp. pp. 90-110; 112-119, cat.-nr. 9-12; Marías, Fernando. Pinturas de Historia, Imágines políticas. Pensando el Salón de Reinos. Madrid: Real Academia de la Historia 2012; López-Rey/ Delenda: Velázquez, pp. 360-362, cat.-nr. 66-69; Simal López, Mercedes: El Real Sitio del Buen Retiro y sus colecciones durante el reinado de Felipe IV. In: José Martínez Millán/ Manuel Rivero Rodríguez (Hg.): Arte, coleccionismo y sitios reales (La corte de Felipe IV (1621-1665): Reconfiguración de la Monarquía católica III/4). Madrid: Ediciones Polifemo 2017, pp. 2339-2566, hier 2741-2472.

58. Covarruvias/ Covarrubias i Leyva, Diego (eds.): Elogios al Palacio Real del Bven Retiro [...]. Madrid: Imprenta del Reyno 1635 
Manuel de Gallegos (Manoel de Galhegos) 1637 in seinem Lobgedicht auf den neuen Palast Silva topográfica al Buen Retiro festhielt ${ }^{59}$ : „Entra en esse Salon; y alegre mira/ la copia de Felipo, que pendiente/ adorna desta puerta lo eminente./ Contempla el fuego que en sus ojos gira,/ considera que airado/ en ginete veloz se ostenda armado. Si así le viera el belga en la camapña/ al Imperio de España/ se rindieran las turbas rebeladas,/ en rayos de decoro fulminadas." Trotz der freundlichen Landschaftsdarstellung verkörperte das Reiterbildnis Philipps IV. von Velázquez also ebenso wie jenes von Rubens den Kampf des Habsburgers gegen die protestantischen Niederländer!

Über diesen beiden Gemälden wurde das Bildnis des Thronfolgers als „beredtes Exemplum“ und Sinnbild der Regierungsfähigkeit des Prinzen präsentiert - in den Worten des Hofdichters: „No ves como veloz, como ligera/ al bello Adonis de hermesura armado/ conduze à par del dia/ acanelada pia?"60. Das Porträt weist den Thronfolger, der mit seinem Pferd eine Levade vollführt, als vollendeten Reiter aus und damit „wird die perfekte Kontrolle des Tieres zum Ausdruck der vollkommenen Herrschaft." ${ }^{\text {"1 }}$ Schon 1640 hatte Diego de Saavedra Fajardo diesen Gedanken in einem Emblem seines Erziehungstraktates für den Infanten aufgegriffen ${ }^{62}$. Welche Aufgaben vom Thronfolger erwartet wurden, hat der königliche Kammerdichter - und daher wohl einer der potentiellen Konzeptverfasser des Ausstattungsprogrammes - Antonio Hurtado de Mendoza 1639 in der Beschreibung der Eidesleistung der castillischen Stände vor dem damals zehnjährigen Baltasar Carlos expressis verbis formuliert, nämlich „de resistir á tantos y tan declarados enemigos de la Iglesia y suyos y de la Augustissima Casa de Austria [...], la defensa de la Fe y del Imperio" 63 .

Eine Bestätigung dieser Interpretation der Reiterporträts von Velázquez liefern uns vor allem zwei an den habsburgischen Prinzen adressierte Erziehungstrakte aus den Jahren 1640 und 1643. Saavedras Schrift unter dem Titel Idea de un Prinicpe politico Christiano [...] dedicada al Principe de las

59. De Gallegos, Manuel: Obras varias al real palacio del Bven Retiro. Madrid: Maria de Quiñones 1637, fol. 2v-3v. Siehe dazu: Ponce Cárdenas, Jesús: Pintura y Panegírico. Usos de la écfrasis en Manoel de Galhegos. In: Versants 65 (2018) nr. 3, pp. 97-123.

60. Zitiert in: Warnke: Reiterbildnis, pp. 146-159.

61. Pfisterer, Salón de Reinos, p. 229, bezieht die Interpretation auf das Porträt Philipps IV.

62. Mará del Carmen Heredia Moreno/ Juana Hidalgo Ogáyar+: Intercambio de regalos entre la realeza europea y mercedes reales por servicion prestados a la corona (1621-1640). In: De Arte 15 (2016), pp. 150-167, hier 159-160.

63. Hurtado de Mendoza, Antonio de: Ceremonial que se observa en España para el juramento de Príncié heredditario, ó convocacion de las cortes de Castilla, segun se ha executado dese el juramento del Príncipe Nostro Sr. D. Baltasar Carlos, primero de este nombre. Madrid: Imprenta de Gonzales 1789, p. 17. Verständlicherweise wurde auch der uneheliche und militärisch aktive Sohn Philipps IV., Don Juan José de Austria, schon 1648 von José de Ribera in dieser Form porträtiert: García-Frías Checa, Carmen/ Javier Jordán de Urríes y del Colina (Hg.): El Retrato en las colecciones reales pe Patrimonio Nacional de Juan de Flandes a antonio López, Ausstellungskatalog. Madrid: Patrimonio Nacional 2014, pp. 212-216, cat.-nr. 29 (Gabriele Finaldi). 
Españas nuestro Señor visualisiert nämlich schon auf dem Titelkupfer der 1640 in München erschienenen Erstausgabe die Ideologie des Salon de Rei$n o s^{64}$ in Kurzform (Abb. 16): Der in einer fensterartigen Nische präsentierte Buchtitel wird von den Reiterbildnissen Philipps IV. und des Kardinalinfanten flankiert. Auf deren Sockeln erscheinen die Inschriften VIRTVTEM EX ME sowie EX ME LABOREM ET FORTVNAM und verweisen auf Vater sowie Onkel des Infanten als dessen direkte Tugendvorbilder. Der Erscheinungsort München und die Funktion des Autors als spanischer Botschafter am bayerischen Hof sowie als Diplomat am Friedenskongress in Münster, lassen wohl keinen Zweifel an einer zwischen den beiden Zweigen der Casa de Austria abgestimmten Strategie. Das bestätigt auch der 1643 vom Jesuiten Juan Eusebio Nieremberg in Madrid publizierte Tugendspiegel Corona virtuosa y virtud coronada en que se proponen los frutos de la virtud de un principe junatmento con los heroicos exemplos de virtudes de los emperadores de la Casa de Austria y reyes de España. Denn dieser präsentiert nicht nur in bewusster Parallelisierung Tugendexempla von Rudolf I. bis Ferdinand II. auf kaiserlicher und von Ferdinand dem Heiligen bis Philipp III. auf spanischer Seite, sondern wurde 1675 in Wien auch in einer lateinischen Version publiziert $!^{65}$ Spätestens 1646 wurde eine Heirat von Baltasar Carlos mit dessen Cousine Erzherzogin Maria Anna von Philipp IV. sowie vom spanischen Staatsrat offiziell diskutiert ${ }^{66}$

In beiden Zweigen der Casa de Austria galt also im 2. Viertel des 17. Jahrhunderts offensichtlich das Reiterbildnis als der den Habsburgern und ihrem unter göttlichem Schutz stehenden Schlachtenglück angemessene Porträttypus. Dies beweist auch ein den Römischen König Ferdinand IV. und potentiellen Bräutigam der Infantin María Teresa als neuen Konstantin zeigender Kupferstich aus dem Jahre 1653 (Abb. 17) ${ }^{67}$. Georg Lackner stellte den Thronfolger auf kurbettierendem Pferd vor einer Schlachtenszene mit türkischen Kriegern dar. Durch das am Himmel erscheinende (ungarische) Doppelkreuz mit dem Motto IN HOC SIGNO VINCES (In diesem Zeichen wirst du siegen) wird der Kampf des römischen und ungarischen Königs gegen die Osmanen mit dem Triumph des ersten christlichen Kaisers über seine heidnischen Gegner gleichgesetzt. Das Idealbild des Herrschers, der wie

64. D. De Harp Scheffer: Aegidius Sadeler to Raphael Sadeler (Hollstein Dutch \& Flemish etchings, engravings and woodcuts 1450-1700, xxi), 1980, p. 194, cat.n. 13.

65. Zum Autor siehe: D. Scott Hendrickson: Jesuit Polymath of Madrid. The Literary Enterprise of Juan Eusebio Nieremberg (1595-1658) (Jesuit Studies 4), Leiden/ Boston: Brill 2015.

66. Claudia Ham: Die Verkauften Bräute. Studien zu den Hochzeiten zwischen österreichischen und spanischen Habsburgern im 17. Jahrhundert, Dissertation der Universität Wien, Wien 1995, pp. 169182.

67. Polleroß, Friedrich: Das sakrale Identifikationsporträt. Ein höfischer Bildtypus vom 13. bis zum 20. Jahrhundert Manuskripte zur Kunstwissenschaft 18). Worms: Wernersche Verlagsgesellschaft 1988, Abb. 99; Welt des Barock, Ausstellungskatalog St. Florian. Linz: Ö̈. Landesregierung 1986, p. 72, cat.-nr. 1.31 . 
Konstantin seine Gegner im Vertrauen auf das Kreuz bekämpft, war ja ein Kernmotiv der Pietas Austriaca und wurde auf Rudolf I. zurückgeführt ${ }^{68}$.

Um 1668/70 schuf der spanische Hofmaler Sebastián de Herrera Barnuevo ein Reiterporträt des jungen Königs Karl II., bei welchem er direkt das Reiterporträt des Baltasar Carlos von Velázquez paraphrasierte und den jugendlichen Habsburger ebenfalls mit dem Kommandostab porträtierte ${ }^{69}$. Ein etwas jüngeres Reiterbildnis Karls von Herrera Barnuevo (Abb. 18) folgte hingegen dem ikonographischen Vorbild des Kardinalinfanten von Rubens ${ }^{70}$, und in beiden Fällen sollte der von Beginn an kränkliche Prinz der kritischen Öffentlichkeit als potenzieller Heerführer vorgeführt werden. Ein großformatiges Porträt dieser Art war wohl auch dazu bestimmt, die Herrscherserie in den beiden Madrider Residenzen fortzusetzen, war es doch naheliegend. Karl II. auch visuell dem Vorbild Karls I. (als Kaiser der V.) nacheifern zu lassen $^{71}$. Parallel dazu oder als Gegenstück zu einem etwas jüngeren Reiterporträt des Königs von Francisco Rizi war offensichtlich vom selben Maler auch ein Reiterporträt der Königinmutter Maria Anna von Österreich (also der Schwester des oben genannten Ferdinand IV.) geplant, welches die spanische Regentin in Witwentracht und mit Marschallsstab (!) auf dem Pferde präsentiert, während Fama mit der Trompete und der Königskrone herniederschwebt $^{72}$. Das Bildnis ist nur in einer Entwurfszeichnung überliefert, weshalb zu vermuten ist, dass es entweder nach der Entmachtung Maria Annas nicht ausgeführt oder durch das Bildnis der ersten Gattin des Königs ${ }^{73}$ ersetzt wurde.

Wie sehr das Reiterporträt bereits zu einem ,Familienlogo' der Habsburger geworden ist, verraten vor allem die weiblichen Bildnisse, zählen doch Darstellungen von Fürstinnen hoch zu Ross eher zu den Ausnahmen ${ }^{74}$. Eine Ausnahme, die die Regel bestätigt, bilden jedoch die zunächst in Manuskripten gemalten und seit der Mitte des 16. Jahrhunderts in der Druckgraphik geläufigen seriellen Darstellungen der burgundischen Herzoginnen bzw. niederländischen Statthalterinnen auf dem Pferd wie es bei den männlichen Regenten dieser Provinzen üblich war. Mit den Bildnissen der Maria von Bur-

68. Coreth: Pietas Austriaca, pp. 38-44.

69. Pascual Chenel, Álvaro: Sebastián de Herrera Barnuevo y los retratos ecuestres de Carlos II durante su minoría de edad. Fortuna iconográfica y propaganda política. In: Reales Sitios XLVI (2009) Nr. 182, pp. 4-27, hier 4-12; Pascual Chenel: El retrato de Estado, pp. 431-447; Mínguez: Carlos II, pp. 206212; Sancho/ Souto: El arte regio, p. 172.

70. Dorotheum: Auktion Alte Meister vom 24.4.2018, Lot nr. 77.

71. Schon 1666 zeigte eine Buchillustration den Prinzen vor einem Denkmal des Kaisers: Souto/ Sancho: Carlos II, Fig. 5.

72. Souto/ Sancho: Carlos II, pp. 54-55, fig. 10.

73. Zum Reiterporträt der María Louis de Orleáns siehe: Pascual Chenel, Álvaro. El retrato de Estado durante el reinado de Carlos II. Imagen y propaganda (Tesis Doctorales Cum Laude A/33), Madrid: FUE 2010, pp. 574-575.

74. Vgl. dazu: Liedtke: Royal Horse. 
gund sowie der Maria von Ungarn und der Margarethe von Parma hatten der spanische Hof und seine Künstler eine entsprechende Ikonographie vor Augen $^{75}$. Bereits um 1525 entstand außerdem ein Holzschnitt, der Karl V. und Ferdinand I. auf der einen sowie ihre Schwestern Isabella, Johanna, Katharina und Maria auf der anderen Seite zu Pferd einander gegenüber stellt ${ }^{76}$. Daher überrascht es kaum, wenn ein aus Straßburg stammender und in deutschen Städten tätiger Kupferstecher wie Abraham Aubry bei einem Porträtstich der kaiserlichen Braut María Margarita Teresa (Abb. 19) auf ein älteres Blatt zurückgreift, welches die französische Königin Anna von Österreich zeigt. Dass er aber die künftige Kaiserin gerade mit einem Reiterporträt würdigte, ist wohl ebenso wenig Zufall wie die Tatsache, dass ein Porträt ihrer spanischen Tante als Vorbild diente ${ }^{77}$. Ebenfalls ein französisches Modell und damit die Darstellung einer Infantin auf dem französischen Thron wurde offensichtlich 1666 vom Nürnberger Verleger Johann Hoffman ,abgekupfert', um Kaiser Leopold I. und seine spanische Braut zu Pferde zu porträtieren ${ }^{78}$.

Nach dieser Übertragung des ,feministischen' Typus vom spanischen an den Wiener Hof, war es nur logisch, dass der Gedanke einer monumentalen habsburgischen Reiterversammlung bei der Hochzeitsoper Il Pomo d'oro zu Ehren Leopolds I. und seiner spanischen Braut Margarita 1668 in ephemerer, aber künstlerisch imposanter Form aufgegriffen wurde. Das Bühnenbild zum Prolog von Ludovico Ottavio Burnacini zeigt unter dem Titel Teatro della Gloria Austriaca im Zentrum der Perspektive eine Apotheose Leopolds I. auf kurbettierendem Pferd, der aus dem Himmel mit einem Lorbeerkranz bekrönt wird. Umgeben ist der Herrscher von einer Architektur mit korinthischen Marmorsäulen zwischen denen auf jeder Seite sechs vergoldete Reiterdenkmäler von Ahnen bzw. Amtsvorgängern aufgestellt sind. Davor erscheinen die Personifikationen des Reiches, der Erbländer und der spanischen Territorien in Europa und Amerika, um die weltweite Herrschaft des

75. Haag, Sabine/ Dagmar Eichberger/ Annemarie Jordan Gschwend (Hg.): Frauen, Kunst und Macht, Ausstellungskatalog Innsbruck. Wien: Kunsthistorisches Museum 2018, p. 38. Die Tradition lässt sich bis ins 15. Jahrhundert zurückfuhren, als Maria von Burgund in der handschriftlichen "Chronik von Flandern“ zu Pferd als Erbin des Herzogtums porträtiert wurde. Darauf hat zuletzt Sabina de Cavi hingewiesen: De Cavi: Nuove fonti, pp. 137-140.

76. Vorstenportretten uit de eerste helft van de 16de eeuw. Houtsneden als propaganda. Ausstellungskatalog Amsterdam: Rijksmuseum 1972, cat.-nr. 4, Abb.

77. Polleroß: Reiterporträt, fig. 23 und 24. Es wäre daher auch nicht verwunderlich, wenn das erste Reiterporträt Ludwigs XIV. von Charles Lebrun, das nur in Kopien überliefert ist, nicht nur zufällig, sondern doch bewusst dem Rubens'schen Porträttypus des Schwiegervaters in Madrid folgte: Bril, Damien. „A la curiosité des genres. Louis XIV. et le portrait équestre“. artibus et historiae XXXV (2014), nr. 69, pp. 213-231.

78. Pelc, Milan: Der Sammler und sein Kaiser. Leopold I. in der Sammlung Valvasor - Die Ikonographie des Kaisers aus der Perspektive eines adeligen Zeitgenossen. In: Werner Telesko (Hg.): Die Repräsentation der Habsburg-Lothringischen Dynastie in Musik, visuellen Medien und Architektur/ Representing the Habsburg-Lorraine Dynasty in Music, Visual Media and Architecture 1618-1918. Wien/ Köln/ Weimar: Böhlau Verlag 2017, pp. 231-250, hier , 238-239, Abb. 4. Vgl. dazu etwa das Doppelreiterporträt von Ludwig XIII. und Anna von Österreich von 1639: Bril: Le Brun, fig. 4. 
Hauses Habsburg zu versinnbildlichen (Abb. 20) ${ }^{79}$. Ebenso wie sein Neffe und Schwager im Salón de Reinos wurde der junge Herrscher auf dem steigenden Pferd gleichzeitig als Erbe der Tugenden seiner Vorfahren (auf schreitenden Pferden) und als Erbe eines weltweiten Herrschaftsgebietes präsentiert.

Es waren dann vor allem die Siege der christlichen Heere über die Osmanen ab 1683, die zahlreiche Darstellungen Leopolds I. als Triumphator hervorbrachten. Da der Herrscher aus der belagerten Stadt geflohen war und auch danach an keiner Schlacht teilnahm, verkündigte die zeitgenössische Propaganda, dass der Habsburger durch sein Gebet die Truppen unterstützt hätte. Ungeachtet dieser Thematik wurden die militärischen Erfolge in Ungarn als Triumph des christlichen Abendlandes über die islamischen Osmanen und der Kaiser auf Flugblättern und volkstümlichen Stichen auf steigendem Pferd in der Schlacht als „empereur de guerre“ gefeier ${ }^{80}$. Ein Wiener Thesenblatt von J. Schormer und Johann Franz Samuel Wussim aus dem Jahre 1687 mit der Unterschrift „Illlinc protegeris Virtute hinc Numine Caesar: Tutior ad Lauros non valet esse via" zeigt Leopold in antikem Kostüm auf steigendem Pferd vor einer Schlachtenszene (Abb. 21). Die göttliche Hilfe wird hier durch einen Engel mit Feuerschwert und ungarischem Schild sowie durch den Adler Jupiters mit dem Blitzbündel veranschaulicht, und darüber thront die Personifikation der göttlichen Voraussicht. Die Graphik kopierte unmittelbar ein Thesenblatt mit dem Bildnis König Ludwig XIV. von Frankreich ${ }^{81}$, aber die Ikonographie der himmlischen Schutzpatrone war bereits beim Bildnis des Kardinalinfanten vorweggenommen worden.

In Wien wurde in der kaiserlichen Kunstkammer die Serie der Reiterstatuetten nach den Siegen über die Osmanen und der Krönung Josefs I. zum Römischen König mit Kleinmonumenten von Leopold I. und Josef I. ebenfalls fortgesetzt wurde, allerdings nicht in Bronze, sondern von Matthias Steinl in der von Leopold bevorzugten hochbarocken Gattung der Elfenbeinschnitzerei ${ }^{82}$ (Abb. 22).

79. Polleroß, Friedrich (ed.). Federschmuck und Kaiserkrone. Das barocke Amerikabild in den habsburgischen Ländern. Ausstellungskatalog Schlosshof. Wien: Künstlerhaus 1992, cat.-nr. 7.18 (Andrea Sommer-Mathis).

80. Goloubeva, Maria: The Glorification of Emperor Leopold I in Image, Spectacle and Text (Veröffentlichungen des Institutes für Europäische Geschichte Mainz 184). Mainz: Philipp von Zabern 2000, pp. 122-141 („Conquering the Thracian: the Emperor's Image and the Turkish Campaigns“); Wrede, Martin: Türkenkrieger, Türkensieger. Leopold I. und Ludwig XIV. als Retter und Ritter der Christenheit. In: Kampmann/ Krause/ Krems/ Tischer, pp. 149-165; Wrede, Martin: Die ausgezeichnete Nation. Identitätsstiftung im Reich Leopolds I. in Zeiten von Türkenkrieg und Türkensieg, 1663-1699. In: Eckhard Leuscher/ Thomas Wunsch (Hg.): Das Bild des Feindes. Konstruktion von Antagonismen und Kulturtransfer im Zeitalter der Türkenkriege. Berlin: Gebr. Mann Verlag 2013, pp. 19-31.

81. Polleroß, Friedrich: Paraphrases artistiques ou contre-images politiques? Les empereurs et les rois de France dans des gravures parallèles. In: Bulletin du Centre de recherche du château de Versailles [mis en ligne le 03 avril 2018, URL: https://journals.openedition.org/crcv/14924

pp. 1-33, fig. 12.

82. Pühringer-Zwanowetz, Eleonore. Matthias Steinl. Wien/ München: Herold 1966, pp. 42-54; Haag, Sabine. „...das artigste...alss ich mein tage wass gesehen habe..... Elfenbeinkunst im kaiserlichen 
Ebenso konsequent wurde in Madrid die Serie der lebensgroßen Gemälde im Salón de los Espejos des Alcázar weiter geführt. Spätestens 1694 hat man dort als Pendants zu den Gemälden Karls V. von Tizian und Philipps IV. von Rubens die auch in ihrer Monumentalität mit der Allegorie des Glaubens dem flämischen Vorbild folgenden Reiterporträts von Karl II. und seiner zweiten Gattin Marianna von Pfalz-Neuburg von Luca Giordano installiert ${ }^{83}$.

Damit war das Reiterbildnis endgültig zum Kennzeichen der spanischen Linie der Habsburger geworden, und es war nur folgerichtig, dass man sich auch auf diesen Porträttypus berief, als Erzherzog Karl 1703 zum Nachfolger des spanischen Königs deklariert wurde ${ }^{84}$. So folgt ein anonymer österreichischer Kupferstich um 1703 offensichtlich sowohl was die Komposition des Pferdes betrifft als auch hinsichtlich der Kleidung des Reiters (Mantelkleid und Federhut) direkt dem Reiterporträt Karls II. von Jacob Peeters in Antwerpen aus der Zeit um $1670^{85}$. Es gibt jedoch auch Beispiele mit steigendem Pferd: Ein anonymer Kupferstich um 1670 zeigt den jungen spanischen Herrscher vor einer Jagdszene, während eine Graphik des französischen Künstlers Henri Bonnart Erzherzog Karl um 1703 als „CAROLUS III. Hispaniarum et Indiarum Rex" ebenfalls mit spanischem Mantelkleid und Federhut zu Pferd vor einer Seeschlacht porträtiert ${ }^{86}$.

Nach 1712 ließ Karl VI. die Serie der Elfenbeinmonumente von Matthias Steinl um sein eigenes Kunstkammermonument ergänzen ${ }^{87}$. Und im Kaisersaal des Augustinerchorherrenstiftes St. Florian, der ausdrücklich dem Tri-

Wien der Barockzeit. In Bückling, Maraike/ Haag, Sabine (eds.). Elfenbein. Barocke Pracht am Wiener Hof, Ausstellungskatalog. Frankfurt am Main: Liebighaus 2011, pp. 14-31.

83. Pascual Chenel: El retrato de Estado, pp. 448-453 und 580-581; Úbeda de los Cobos, Andrés: Luca Giordano y Carlos II. In: Fernando Checa Cremades (Hg.): Cortes del Barroco da Bernini y Velázquez a Luca Giordano, Ausstellungskatalog Madrid. Madrid SEACEX 2003, pp. 73-84, hier 77-78, fig. 5.3.-5.5.

84. Zum Bilderstreit während des Spanischen Erbfolgekrieges siehe: Winkler, Hubert. Bildnis und Gebrauch. Zum Umgang mit dem fürstlichen Bildnis in der frühen Neuzeit. Vermählungen Gesandtschaftswesen - Spanischer Erbfolgekrieg (Dissertationen der Universität Wien 239), Wien: Universität Wien 1993, pp. 221-251; Polleroß, Friedrich. Hispaniarum et Indiarum Rex. Zur Repräsentation Kaiser Karls VI. als König von Spanien. In Jané, Jordi (ed.). Denkmodelle. Akten des 8. Spanischösterreichischen Symposions 13.-18.Dezember 1999 in Tarragona. Tarragona: Universitas Taragonensis 2000, pp. 121-175, hier 133, Abb. 5; Bodart, Diane H. „Philippe V ou Charles III? La guerre des portraits à Rome et dans les royaumes italiens de la couronne d’Espagne, in Álvarez-Ossorio, Antonio/ García García. Bernardo J./ León, Virginia (eds.). La pérdida de Europa. La guerra de Succesión por la Monarquía de España, Madrid: Carlos de Amberes 2007, pp. 99-133; Polleroß, Friedrich. Die Kunst der Diplomatie. Auf den Spuren des kaiserlichen Botschafters Leopold Joseph Graf von Lamberg (1653-1706). Petersberg: Michael Imhof Verlag 2010, pp. 373-412.

85. Polleroß, Friedrich: Soberanía e imagen dinástica en la política artística de los Habsburgo ante la crisis sucesoria española. Paralelismos y diferencias. In: Bernardo J. García García (Hg.): En Nombre de la Paz. La Guerra de Sucesión Española y los Tratados de Madrid, Utrecht, Rastatt y Baden 1713-1715, Ausstellungskatalog. Madrid: Fundación Carlos de Amberes 2013, pp. 77-89, hier fig. 11 u. 12.

86. Pascual Chenel: Sebastián de Herrera Barnuevo, fig. 16; Polleroß: Reiterporträt, fig. 28-29.

87. Pühringer-Zwanowetz, Steinl. pp. 55-56; Bückling, Mareike: Matthias Steinl (1643/44-1727). In: Bückling/ Haag, Elfenbein, pp. 134-139. 
umph der Habsburger über die Osmanen gewidmet ist ${ }^{88}$, wurden schließlich um 1727/28 zwei großformatige Reiterporträts über den Kaminen angebracht: eines zeigt Prinz Eugen von Savoyen und das andere Kaiser Karl VI. ${ }^{89}$. Bezeichnenderweise wurde der Kaiser hier mit Küriss und Dreispitz porträtiert, also in der damals noch seltenen Form einer Felduniform (Abb. 23). Wenngleich der Typus des Reiterporträts zu diesem Zeitpunkt bei Fürsten und auch bei Adeligen so allgemein geschätzt und weit verbreitet war, dass man kaum mehr eine individuelle oder familiäre Besonderheit darin sehen konnte, so war zumindest das Bewusstsein, dass die habsburgischen Siege gegen die Ungläubigen mit göttlicher Hilfe erkämpft wurden, in St. Florian noch immer ebenso ausgeprägt wie zur Zeit Karls V. und in den Anfängen der Gattung des habsburgischen Reiterporträts.

\section{BIBLIOGRAFÍA}

Ammann, Gert: Ruhm und Sinnlichkeit. Innsbrucker Bronzeguss 1500-1650 von Kaiser Maximilian I. bis Erzherzog Ferdinand Karl. Innsbruck: Tiroler Landesmuseum, 1996.

ARndT, Johannes: «Die Kriegspropaganda in den Niederlanden während des achtzigjährigen Krieges gegen Spanien 1568-1648» en: Frieden und Krieg in der Frühen Neuzeit. Die europäische Staatenordnung und die außereuropäische Welt (Asch, Voss, Wrede, eds.). Múnich: Wilhelm Fink, 2001, pp. 239-258.

Baticle, Jeannine: «El retrato ecuestre del rey Felipe IV», en: Velázquez (Svetlana, coord.). Barcelona: Galaxia Gutenberg,1999, pp. 57-69.

Von Birken, Sigismund: Spiegel der Ehren des Höchstlöblichen Kayser und Königlichen Ertzhauses Österreich. Núremberg: Michael und Johann Friedrich Endter, 1668.

Brassat, Wolfgang: «Für die Einheit der katholischen Liga. Zum politischen Gehalt des Eucharistie-Zyklus Peter Paul Rubens», en: Idea. Jahrbuch der Hamburger Kunsthalle VII, 1988, pp. 43-62.

Bodart, Diane H. : «Enjeux de la présance en image: les portraits du roi d'Espagne dans l'Italie du XVIIe siècle», en The Diplomacy of Art: Artistic Creation and Politics in Seicento Italy. Papers from a Colloquium held at

88. Telesko, Werner. Der „Marmorsaal“ im Augustiner-Chorherrenstift St. Florian. Die Verherrlichung des Türkensiegers Kaiser Karls VI. im Lichte schriftlicher und bildlicher Quellen. In: Jahrbuch des oberösterreichischen Musealvereines 158 (2013), pp. 211-258.

89. Wutzel, Otto: Das Augustiner-Chorherrenstift St. Florian. Linz: Rudolf Trauner Verlag 1998, Abb. 115-116; Friedrich Polleroß: Karl VI. im Porträt - Typen \& Maler. In: Stefanie Hertel/ Franz-Stefan Seitschek (Hg.): Herrschaft und Repräsentation in der Habsburgermonarchie. Berlin 2021, pp. 347-373. 
the Villa Spelman (Cropper ed.), Florencia: Nuova Alfa, 2000, pp. 7799.

— : «Philippe V ou Charles III? La guerre des portraits à Rome et dans les royaumes italiens de la couronne d'Espagne», en La pérdida de Europa. La guerra de Succesión por la Monarquía de España (Álvarez-Ossorio García, León, eds.). Madrid: Carlos de Amberes, 2007, pp. 99-133.

- : «Statues royales et géographie du pouvoir sous les règnes de Charles II et de Louis XIV». ¿Louis XIV espagnol? Madrid et Versailles, images et modèles (Sabatier, Torreoni, eds.). Versailles: Maison des Sciences de L'homme, 2009, pp. 95-116.

- : Pouvoirs du portrait sous les Habsbourg d'Espagne. Paris: CTHs, 2011

Boon, K. G., Verbeek, J.: Van Ostade-De Passe. Amsterdam: Menno Hertzberger, 1949

Brea, AzCue Leticia: «Panorama de la escultura cortesana y el coleccionismo escultórico nobiliario en la época de Felipe IV. Estado de la cuestión», en Arte, coleccionismo y sitios reales. La corte de Felipe IV (1621-1665): Reconfiguración de la Monarquía católica III/4 (Millán, Rodríguez, eds.), Madrid: Ediciones Polifemo, 2017, pp. 2871-3001.

BRIL, DAMIEN : «A la curiosité des genres. Louis XIV et le portrait équestre», Artibus et historiae XXXV, 69, 2014, pp. 213-231.

Brown, Jonathan (ed.): Velázquez, Rubens y Van Dyck- Pintores cortesanos del siglo XVII. Madrid: Ediciones El Viso, 1999.

-: «The Hall of Realms and the Thirty Years' War», en Frieden und Krieg in der Frühen Neuzeit. Die europäische Staatenordnung und die außereuropäische Welt (Asch, Voss, Wrede (eds.), Múnich: Wilhelm Fink, 2001, pp. 207-214.

Brown, Jonathan, Elliott, John H.: A Palace for a King. The Buen Retiro and the Court of Philip IV, New Haven: Yale University Press, 1980.

BüCKling, MareIKE: Kaiserliches Elfenbein Matthias Steinl (1643/44-1727). Viena: KHM, 2007, pp. 134-139.

Carr, Dawson W.: Painting and Reality: The Art and Life of Velázquez, en Velázquez (CARr, Bray, Elliot, Keith, Portús), London: Yale University Press, 2006, pp. 26-53.

Carr, Dawson W., Bray, Xavier, Elliott, John H., Keith, Larry, PorTús, JAVIER, London: Yale University Press, 2006.

Checa Cremades, Fernando (ed.): El Real Alcázar de Madrid. Dos siglos de arquitectura y coleccionismo en la corte de los Reyes de España. Madrid: Nerea, 1994.

-: Tiziano y la monarquía hispánica. Usos y funciones de la pintura veneciana en España (siglos XVI y XVII). Madrid: Nerea, 1994.

-: Carlos V, a caballo, en Mühlberg, de Tiziano. Madrid: TF, 2001. 
-: «Tiziano y las estrategias de la representatión del poder en la pintura del Renacimiento», en: La Restauración de „El emperador Carlos V a caballo en Mühlberg" de Tiziano. Madrid: Museo Nacional del Prado, 2001, pp. 43-70.

-: Cortes del Barroco de Bernini y Velázquez a Luca Giordano. Madrid: SEACEX, 2003.

Coreth, Anna: "Pietas Austriaca". Österreichische Frömmigkeit im Barock. Viena: Oldenbourg Wissenschaftsverlag, 1982, pp. 45-72.

Covarruvias i leyva, Diego: Elogios al Palacio Real del Bven Retiro. Madrid: Imprenta del Reyno, 1635.

De Cavi, Sabiena: «Nuove fonti per l'iconografia equestre del Salón de los Reinos di Velázquez al Buen Retiro (1628-1634/35)», Locvs amoenvs, 11, 2011-2012, pp. 129-149.

De Cevallos, Jerónimo: Arte real para del buen govierno de los Reyes, y Principes, y de sus vasallos. Toledo: Jerónimo de Cevallos, 1623.

De Hoop SCheffer, Dieuwke: Vorstenportretten uit de eerste helft van de 16de eeuw. Houtsneden als propaganda. Amsterdam: Rijksmuseum, 1972.

Diels, Ann: The Shadow of Rubens. Print Publishing in 17th-century Antwerp. Prints by the history painters Anselm van Diepenbeeck, Cornelis Schut and Erasmus Quellinus II. London: Harvey Miller, 2009.

Emmens, Jan E.: «Las Meninas von Velázquez: Fürstenspiegel für Philipp IV», en: Las Meninas im Spiegel der Deutungen (Greub, ed.). Berlin: Dietrich Reimer, 2001, pp. 115-133.

Falleti, Franca, (ed.): Pietro Tacca. Carrara, la Toscana, le grandi corti europee. Florencia: Mandragora, 2007.

Falomir Faus, Miguel: «Tiziano, el Aretino y las "alas de la hipérbole". Adulación y alegoría en el retrato de los siglos XVI y XVII», en La Restauración de "El emperador Carlos V a caballo en Mühlberg" de Tiziano, Madrid: Museo Nacional del Prado, 2001, pp. 71-86.

FERNÁNDEZ, L. J. JOSÉ: «„Der Salón de Reinos des Buen Retiro-Palastes in Madrid“», en 1648. Krieg und Frieden in Europa (Bussmann, SchelLING, eds.). Münster: 350 J. Westfälischer Friede, 1998, pp. 121-129.

De Gallegos, Manuel: Obras varias al real palacio del Bven Retiro. Madrid: Maria de Quiñones, 1637.

Fillitz, Hermann: «Tizians Reiterbildnis Kaiser Karls V», en: Orient und Okzident im Spiegel der Kunst (Günther, Müller, eds.). Graz: Kunsthistorisches Institut Universität, 1986, pp. 81-86.

García García, Bernardo J.: En Nombre de la Paz. La Guerra de Sucesión Española y los Tratados de Madrid, Utrecht, Rastatt y Baden 1713-1715, Madrid: Fundación Carlos de Amberes, 2013. 
García-Frías Checa, Carmen; Jordán De Urríes y De la Colina, JaVIER (eds.): El Retrato en las colecciones reales del Patrimonio Nacional de Juan de Flandes a Antonio López. Madrid: Patrimonio Nacional, 2014.

Goloubeva, Maria: The Glorification of Emperor Leopold I in Image, Spectacle and Text. Mainz: Philipp von Zabern, 2000.

Gürtler, Elisabeth, brasche, Armin, Van Bakel, René: 450 Jahre Spanische Hofreitschule: 450 Years Spanish Riding School. Baden: Edition Lammerhuber.

HAAG, SABINE: «"...Das artigste...alss ich mein tage wass gesehen habe...“. Elfenbeinkunst im kaiserlichen Wien der Barockzeit», en: Elfenbein. Barocke Pracht am Wiener Hof (Bückling, Haag, eds.). Fráncfort del Meno: Liebighaus, 2011, pp. 14-31.

—: Velázquez. Múnich: Hirmer, 2014

Haag, Sabine, Eichberger, Dagmar, Jordan Gschwend, Annemarie (eds.): Frauen, Kunst und Macht, Ausstellungskatalog Innsbruck. Viena: Kunsthistorisches Museum, 2018.

Hagenow, Elisabeth Von: «Das allegorisch kommentierte Herrscherbildnis- Herrscherpropaganda in den Konfessionskriegen des 16. und 17. Jahrhunderts», en: 1648. Krieg und Frieden in Europa, Kunst und Kultur (Bussmann, Schelling, eds.). Münster, Bruckmann, 1998, pp. 61-68.

-: Bildniskommentare. Allegorisch gerahmte Herrscherbildnisse in der Graphik des Barock. Entstehung und Bedeutung, Nueva York: Georg Olms, 1999.

Heinen, Ulrich: «Loyalität - Diplomatie - Religion. Peter Paul Rubens Beitrag zum Überleben der Habsburgischen Niederlande», en: Freiheit - Macht - Pracht. Niederländische Kunst im 17. Jahrhundert (FINCHK, Hartje-Grave, eds.), Wuppertal: Von der Heydt-Museum, 2009, pp. 1031.

Hellwag-Konkerth, Karin: «La estatua ecuestre de Felipe IV de Pietro Tacca y la fachada del Alcázar de Madrid», Archivo Español de Arte, 250, 1990, pp. 233-241.

Huemer, Frances : Portraits I. Corpus Rubenianum Ludwig Burchard XIX. Bruselas: Arcade, 1977.

Hurtado De Mendoza, Antonio: Ceremonial que se observa en España para el juramento de Príncié heredditario, ó convocacion de las cortes de Castilla, segun se ha executado dese el juramento del Príncipe Nostro Sr. D. Baltasar Carlos, primero de este nombre. Madrid: Imprenta de Gonzales, 1789.

Jacquot, Dominique: Rubens. Portraits princiers. París: Réunion des Musées Nationaux, 2017. 
KAgAN, Richard L. :«Imágenes y política en la corte de Felipe IV de España. Nuevas perspectiva sobre el Salón de Reinos», en La historia imaginada (Palos, Carrió-Invernizzi, coords.). Madrid: CEEH, 2008, pp. 101-119.

Keller, Ulrich: «Reiterstandbild», en: Politische Ikonographie. Ein Handbuch (Flecker, Warnke, Ziegler, eds.), Múnich: C. H. Beck, 2014, pp. 301-307.

Косн, Евва: «Das barocke Reitermonument in Österreich», Mitteilungen der Österreichischen Galerie, 19/20, 1975-1976, pp. 32-80.

Kuster, Thomas: Hoch zu Ross. Das Reiterstandbild Erzherzog Leopolds V. cat. exp. Innsbruck, Viena: Kunsthistorisches Museum, 2020.

LARSSON, Lars O.: «Antonio Tempesta und das Reiterporträt im 17. Jahrhundert eine typologische Studie», en Wege nach Süden. Wege nach Norden. Aufsätze zu Kunst und Architektur. Als Festgabe zum 60. Geburtstag (Buttlar, Kuder, Nägelke, eds.). Kiel: Ludwig, 1998, pp. 26-35.

Lechner, P. M. Gregor: Das barocke Thesenblatt. Entstehung - Verbreitung - Wirkung. Der Göttweiger Bestand. Göttweig: Göttweig Veröffentlichungen, 1985.

Leesberg, Marjolein, Leeflang, Huigen: Johannes Stradanus. Part III (The New Hollstein. Dutch E Flemish etchings, engravings and woodcuts 1450-1750). Amsterdam: Sound \& Vision Publishers, 2008.

Leuschner, Eckhard: «Roman Virtue, Dynastic Succession and the ReUse of Images. Constructing Authority in Sixteenth and SeventennethCentury Portraiture», Studia Rudolphina, 6, 2006, pp. 5-25.

-:Antonio Tempesta (= The illustrated Bartsch 35/2). Nueva York, NY: Abaris Books, 2007.

Liedtke, Walter A.: The Royal Horse and Rider. Painting, Sculpture and Horsemanship 1500-1800. Nueva York: Abaris Books, 1989.

LiedtKe, Walter A., Moffitt, John F.: «Velázquez, Olivares, \& the baroque equestrian portrait», The Burlington Magazine CXXIII, 942, 1981, pp. 528-537.

Ligo, Larry L.: «Two Seventeenth-century Poems which link Rubens Equestrian Portrait of Philip IV to Titian's Equestrian Portrait of Charles V», Gazette des Beaux-Arts, 112, 1970, pp. 345-354.

Lisken-pruss, Marion: «Rubens im Dienst des Brüsseler Hofes», en Peter Paul Rubens (Finckh, Hartje-Grave, eds.), Wuppertal: Van der HeydtMuseum, 2012, pp. 176-203.

Llombart, Garín, Salort Pons, Salvador (eds.), Velázquez. Roma: Electa, 2001.

Álvarez Lopera, José: «The Hall of Realms: the Present State of Knowledge and a Reconsideration», en: Painting fort the Planet King (ÚBEDA DE Los Совоs, ed.). Madrid: Paul Holberton, 2005, pp. 90-110. 
Mack-Andrick, Jessica: Pietro Tacca. Hofbildhauer der Medici (15771640). Politische Funktion und Ikonographie des frühabsolutistischen Herrscherdenkmals unter den Großherzögen Ferdinando I., Cosimo II. und Ferdinando II. Weimar: VDG, 2005.

Marías, Fernando: Pinturas de Historia, Imágines políticas. Pensando el Salón de Reinos. Madrid: Real Academia de la Historia, 2012.

Martin, John Rupert: The Decoration of the Pompa Introitus Ferdinandi. Bruselas: Arcade, 1972, pp. 147-150.

Matilla, M. José: El Caballo de Bronce. La estatua de Felipe IV. Arte y técnica al servicio de la Monarquía. Madrid: Real Academia de Bellas Artes de San Fernando, 1997.

Millán, M. J., Rodríguez, R. M. (ed.): La corte de Felipe IV (1621-1665): Reconfiguración de la Monarquía católica. Madrid: Polifemo, 2017.

Mínguez, Víctor: La invención de Carlos II. Apoteosis simbólica de la casa de Austria. Madrid: CEEH, 2013.

Mínguez, Víctor, Rodríguez Moya, Inmaculada: Napoleón y el espejo de la antigüedad. Arqueología de las imágenes del poder, Valencia: Universidad de Valencia, 2014.

MoffitT, John F.: «Velázquez y el significado del retrato ecuestre barocco», Goya, 202, 1988, pp. 207-215

—: "An "Emblematization" of Philip IV in the "Salón de Reinos"», Pantheon XLVIII, 1990, pp. 70-75.

-: «The Forgotten Role of a „Determined Christian Knight“ in Titian's Depiction of ,Charles V, Equestrian, at Mühlberg'», Gazette des Beaux Arts, 137, 2001, pp. 37-52.

Miguel Morán Turina: „Pues es más que Alexandro y tu su Apelles“. Notas sobre los retratos ecuestres de Velázquez. In: El Palacio del Buen Retiro y el Nuevo Museo del Prado. Madrid: Museo del Prado 2000, pp. 62-87.

MǘcKaIn, Olaf: «Zwei Gemäldezyklen für den französischen Hof», en: Peter Paul Rubens (Finckh, Hartje-Grave, eds.). Wuppertal: Van der HeydtMuseum, 2010, pp. 268-293.

Oberhaidacher, Jörg: «Zu Tizians Reiterbildnis Karls V. Eine Untersuchung seiner Beziehungen zum Georgsthema», Jahrb. der kunsthistorischen Sammlungen Wien, 78, 1982, pp. 69-90.

Orso, Steven N.: Philip IV and the Decoration of the Alcázar of Madrid. Princeton: Princeton University Press, 1986.

Pascual Chenel, Álvaro: «Sebastián de Herrera Barnuevo y los retratos ecuestres de Carlos II durante su minoría de edad. Fortuna iconográfica y propaganda política», Reales Sitios XLVI, 182, 2009, pp. 4-27.

-: El retrato de Estado durante el reinado de Carlos II. Imagen y propaganda (Tesis Doctorales Cum Laude A/33). Madrid: FUE, 2010, pp. 448-453. 
-: «Algunas consideraicones acerca de los bronces ecuestres italianos de Carlos II vicisitudes, relaciones, usos y funciones», Archivo Español de Arte LXXXV, 338, 2012, pp. 165-180.

Pelc, Milan: Illustrium Imagines. Das Porträtbuch der Renaissance (Studies in Medieval and Reformation Thought LXXXVIII). Leiden: Brill, 2002.

-: «Der Sammler und sein Kaiser. Leopold I. in der Sammlung ValvasorDie Ikonographie des Kaisers aus der Perspektive eines adeligen Zeitgenossen», en: Die Repräsentation der Habsburg-Lothringischen Dynastie in Musik, visuellen Medien und Architektur (Telesko, ed.). Colonia, 2017.

Pfisterer, Ulrich: «Malerei als Herrschafts-Metapher. Velázquez und das Bildprogramm des Salón de Reinos», Marburger Jahrbuch für Kunstwissenschaft, 29, 2002, pp. 199-252.

Pippal, Martina: «„Las Meninas“ von Diego Velázquez-des Rätsels Lösung?», en Velázquez, Anregungen, Vorschläge, Lösungen (Ferino-PaDGEN, ed.), Viena: KHM, 2018, pp. 166-195.

Poeschie, Joachim, Weigel, Thomas, Kusch-Arnhold, Britta, (eds.): Reiterstandbilder von der Antike bis zum Klassizismus. Münster: Rhema, 2008.

Polleroß, Friedrich: «Zur Repräsentation der Habsburger in der bildenden Kunst», en Welt des Barock (Kovács, Feuchtmüller, eds.). Basel: Herder, 1986, pp. 87-104.

-: Das sakrale Identifikationsporträt. Ein höfischer Bildtypus von 13. bis zum 20. Jahrhundert, Worms: Wernersche Verlagsgesellschaft, 1988.

-: (ed.) Federschmuck und Kaiserkrone. Das barocke Amerikabild in den habsburgischen Ländern. Viena: Künstlerhaus, 1992.

-: «Hispaniarum et Indiarum Rex. Zur Repräsentation Kaiser Karls VI. als König von Spanien», en Denkmodelle. Akten des 8. Spanisch-österreichischen Symposions 13.-18.Dezember 1999 in Tarragona (Jané, ed.). Tarragona: Universitas Taragonensis, 2000, pp. 121-175.

—: «"Kaiser, König, Landesfürst: Habsburgische „Dreifaltigkeit“ im Porträt"», en Bildnis, Fürst und Territorium (Beyer, Schütte, Unbehaun, eds.), Berlín: Deutscher Kunstverlag, 2000, pp. 189-218.

-: «Pro decore Majestatis. Zur Repräsentation Kaiser Leopolds I. in Architektur, bildender und angewandter Kunst», Jahrbuch des Kunsthistorischen Museums, 4/5, 2003, pp. 191-295.

-: «Entre "majestas" y "modestas": Sobre la representación del emperador Leopoldo I», en: Cortes del Barroco. De Bernini y Velázquez a Luca Giordano (CheCA, ed.), Madrid: SEACEX, 2003, pp. 151-160.

-: «Bildnisse oder Porträts: Historische Personen und ihr Bild am Beispiel Leopolds I», en: Das Exponat als historisches Zeugnis. Präsentationsformen politischer Ikonographie (Ottomeyer, ed.). Dresden: Sandstein, 2010, pp. 143-156. 
-: Die Kunst der Diplomatie. Auf den Spuren des kaiserlichen Botschafters Leopold Joseph Graf von Lamberg (1653-1706). Petersberg: Michael Imhof, 2010.

-: «Soberanía e imagen dinástica en la política artística de los Habsburgo ante la crisis sucesoria española. Paralelismos y diferencias», en En Nombre de la Paz. La Guerra de Sucesión Española y los Tratados de Madrid, Utrecht, Rastatt y Baden 1713-1715 (García, ed.). Madrid: Fundación Carlos de Amberes, 2013, pp. 77-89.

-: «Paralelismos y diferencias. La política artística de los Habsburgo a finales del siglo XVII y comienzos del XVIII», en: Vísperas de sucesión. Europa y la Monarquía de Carlos II (García, Álvarez-Ossorio, eds.). Madrid: Fundación Carlos de Amberes, 2015, pp. 333-350.

-: Kayserliche Schatz- und Kunstkammer". Die habsburgischen Sammlungen und ihre Öffentlichkeit im 17. Jahrhundert», en Das Haus Habsburg und die Welt der fürstlichen Kunstkammern im 16. und 17. Jahrhundert (HaAg, Kirchweger, Rainer, (eds.). Viena: Holzhausen, 2016, pp. 255295.

-: «Serie, Paraphrase, Kopie: Diego Velázquez und Frans Luycx als Porträtisten der Casa de Austria», en Velázquez: Anregungen, Vorschläge, Lösungen. Schriften des Kunsthistorischen Museums 18 (Ferino-Pagden ed.), Wien: KHM/ Turhout: Brepols, 2018, pp. 142-165.

-: Series, Parphrases, Copies: Diego Velázquez und Frans Luycx as Portraitists of the House of Austria. In: David García Cueto (Hg.): Las copias de obras maestras de la pintura en las colecciones de los Austrias y el Museo del Prado. Actas del congreso internacional, Madrid, Museo del Prado, junio de 2017. Madrid: Museo Nacional del Prado 2021, pp. 128-137.

- : «Paraphrases artistiques ou contre-images politiques? Les empereurs et les rois de France dans des gravures parallèles», Bulletin du Centre de Recherche du Château de Versailles, 2018, pp. 1-33. https://journals.openedition.org/crcv/14924.

Ponce Cárdenas, Jesús: «Pintura y Panegírico. Usos de la écfrasis en Manoel de Galhegos», Versants, 65, 3, 2018, pp. 97-123.

Portús, Javier, García-Máiquez, J., DÁvila, R.: «Los retratos ecuestres de Felipe III y Margarita de Austria de Velázquez para el Salón de Reinos», Boletín del Museo del Prado XXIX, 47, 2011, pp. 16-39.

Pühringer-Zwanowetz, Eleonore: Matthias Steinl. Viena: Herold, 1966.

-: Zur kunstgeschichtlichen Bedeutung des Reiterdenkmales für Kaiser Leopold I. in Klagenfurt. Carinthia, 1965, pp. 714-751.

Reichl-Ham, Claudia: «Der "Lange Türkenkrieg" Rudolfs II. und seine Rezeption im Heeresgeschichtlichen Museum», Jahresbericht 2007 des Heeresgeschichtlichen Museums, 2008, pp. 11-34. 
Rey, José L, Delenda, Odile: Velázquez. Das vollständige Werk. Colonia: Taschen, 2014.

Ribot, Luis, (ed.): Carlos II. El rey y su entorno cortesano, Madrid: CeEH, 2009.

Rodríguez, R. Delfín: Bernini. Roma y la Monarquía Hispánica, Madrid: Museo Nacional del Prado, 2014.

Rosenauer, Artur (ed.): Spätmittelalter und Renaissance. Múnich: Prestel, 2003.

Saenz De Miera, Jesús: «Sobre los géneros artísticos y la representación del poder», en Cortes del Barroco. De Bernini y Velázquez a Luca Giordano (vV. AA.), Madrid: SEACEX, 2003, pp. 216-223.

SANCho, José L., Souto, José L.: «El arte regio y la imagen del soberano», en Carlos II. El rey y su entorno cortesano (RIBOT, ed.), Madrid: CEEH, 2009, pp. 166-185.

— : «El primer retrato del Rey Carlos II: una composición alegórica dibujada por Herrera Barnuevo, Precisinoes sobre la iconografía regia en la Corte del último Austria», Reales Sitios XLVII, 184, 2010, pp. 42-63.

Scholz-Hänsel, Michael: «Bildpropaganda gegen die Anderen. Spanische Kunst im europäischen Kontext der Toleranzdiskussion des Westfälischen Friedens», en 1648. Krieg und Frieden in Europa (Bussmann, Schelling, eds.), Münster: 350 J. Westfälischer Friede, 1998, pp. 131-139.

Simal López, Mercedes: «El Real Sitio del Buen Retiro y sus colecciones durante el reinado de Felipe IV», en Arte, coleccionismo y sitios reales. La corte de Felipe IV (1621-1665): Reconfiguración de la Monarquía católica III/4 (Millán, Rodríguez, eds.), Madrid: Polifemo, 2017, pp. 2.3392.566.

Soler Del Campo, Álvaro: «La batalla y la armadura de Mühlberg en el retrato ecuestre de Carlos V», en La Restauración de „El emperador Carlos V a caballo en Mühlberg" de Tiziano, Madrid: Museo Nacional del Prado, 2001, pp. 87-102.

Soler Del Campo, Álvaro (ed.): El arte del poder. La Real Armería y el retrato de corte. Madrid: SEACEX, 2010.

Telesko, Werner: «Der „Marmorsaal“ im Augustiner-Chorherrenstift St. Florian. Die Verherrlichung des Türkenseigers Kaiser Karls VI. im Lichte schriftlicher und bildlicher Quellen», In Jahrbuch des oberösterreichischen Musealvereines, 158, 2013, pp. 211-258.

-: (ed.) Die Repräsentation der Habsburg-Lothringischen Dynastie in Musik, visuellen Medien und Architektur. Weimar: Böhlau, 2017.

Úbeda De Los Cobos, Andrés: «Luca Giordano y Carlos II», en: Cortes del Barroco da Bernini y Velázquez a Luca Giordano (Checha, coord.). Madrid: SEACEX, 2003, pp. 73-84. 
-: (ed.) Painting for the Planet King. Philip IV and the Buen Retiro Palace. Madrid: Paul Holberton, 2005, pp. 112-119.

Van De Velde, Carl, Vlieghe, Hans: Stadsversieringen te Gent in 1635 voor de blijde intrede van den Kardinaal-Infant. Gante: Stadt Gent, 1969, pp. 51-53.

Van Hout, Nico : «Henry IV valait bien une Galerie!' Rubens' unvollendetes Projekt für das Palais du Luxembourg», en Peter Paul Rubens (Finckh, Hartje-Grave, coords.). Wuppertal: Van der Heydt-Museum, 2012, pp. 88-115.

Veldman, Ilija: Crispijn de Passe's Representations of Emperor Rudolf II., en Konečný, Lubomír/ Slaviček, Lubomir (eds.). Libellus Amicorum Beket Bukovinská. Praha: Artefactum, 2013, 136-155.

Vergara, Alejandro: Rubens and His Spanish Patrons. Melbourne: Cambridge University Press, 1999, pp. 67-75.

-: El universo cortesano de Rubens», en: Velázquez, Rubens y Van Dyck (Brown, ed.), Madrid: Museo Nacional del Prado, 2000, pp. 67-89.

Vitásek, Gabriele: «Das effigiervm Caesarvm opvs, eine illuminierte Kaiserreihe von 1580», Frühneuzeit-Info, 11, 2000, pp. 28-49.

Vhieghe, Hans : Gaspar de Crayer, sa vie es ses oeuvres, Bruselas: Arcade, 1972, pp. 120-121.

Vocelka, Karl: Die politische Propaganda Kaiser Rudolfs II. (1576-1612), Viena: ÖAW, 1981.

VolK, C. Mary: «Rubens in Madrid and the decoration of the Salón Nuevo in the Palace», The Burlington Magazine CXXII, 924, 1980, pp. 168-180.

Volrábová, Alena, Kubíková, Blanka, eds.: RudolfII. a mistři graficke 'ho umění. Praga: Národní Galerie v Praze, 2012.

vv. AA.:Prag um 1600. Kunst und Kultur am Hofe Kaiser Rudolfs II. Viena: Lucas, 1988.

VV. AA.: El linaje del Emperador, Cáceres: C. E. San Jorge, 2000.

Walgrave, Jan: A Royal Image. The Image of the Sovereign since Sir Anthony Van Dyck. Amberes: Provincie Antwerpen, 1999, pp. 131-132.

WARnKe, Martin: «Das Reiterbildnis des Baltasar Carlos von Velázquez», en Amici amico (Gosebruch, Badt, eds.), Múnich: Fink,1968, pp. $217-$ 227.

-: Das Reiterbildnis des Baltasar Carlos von Velázquez. Nah und Fern zum Bilde. Beiträge zu Kunst und Kunsttheorie. Colonia: Dumont, 1997, pp. 146-159.

Watson, Katharine: Pietro Tacca. Successore to Giovanni Bologna, Londres: Garland, 1983.

Wehlen, Bernhard: „Antrieb und Entschluss zu dem was geschieht". Studien zur Medici-Galerie von Peter Paul Rubens. Múnich: Scanneg, 2008. 
Wethey, E. Harold: The Paintings of Titian II. The Portraits. London: Phaidon, 1971.

Wilmers, Gertrude: Cornelis Schut (1597-1655). A Flemish Painter of the High Baroque, Turnhout: Brepols, 1996, pp. 83-85.

Winkler, Hubert: Bildnis und Gebrauch. Zum Umgang mit dem fürstlichen Bildnis in der frühen Neuzeit. Vermählungen - Gesandtschaftswesen - Spanischer Erbfolgekrieg (Dissertationen der Universität Wien 239), Viena: Universidad de Viena, 1993.

WOOLletT, T. ANNE: «Faith and Glory. The Infanta Isabel Clara Eugenia and the ,Triumph of the Eucharist'», en Spectacular Rubens. The Triumph of the Eucharist (Vergara, Woollett, eds.). Los Angeles: The J. Paul Getty Museum, 2014, pp. 10-29.

Wrede, Martin: «Der Kaiser, das Reich und der deutsche Norden. Die publizistische Auseinandersetzung mit Schweden im Ersten Nordischen und Holländischen Krieg», en: Frieden und Krieg in der Frühen Neuzeit. Die europäische Staatenordnung und die außereuropäische Welt (Asch, Voss, Wrede, eds.). Múnich: Wilhelm Fink, 2001, pp. 349-373.

—: «Türkenkrieger, Türkensieger. Leopold I. und Ludwig XIV. als Retter und Ritter der Christenheit», en Bourbon - Habsburg - Oranien. Konkurrierende Modelle im dynastischen Europa um 1700 (Kampmann, Krause, Krems, Tischer, eds.). Köln, Weimar, Viena: Böhlau, 2008, pp. 149-165.

-: «Die ausgezeichnete Nation. Identitätsstiftung im Reich Leopolds I. in Zeiten von Türkenkrieg und Türkensieg 1663-1699», Das Bild des Feindes. Konstruktion von Antagonismen und Kulturtransfer im Zeitalter der Türkenkriege (WunsCH, Leugner, eds.). Berlín: Gebr. Mann, 2013, pp. 19-31.

Wutzel, Отто: Das Augustiner-Chorherrenstift St. Florian. Linz: Rudolf Trauner 1998.

Zikas, Dimitrios : «„Ars sine scientia nihil est“" Il contribuito di Pietro Tacca al bronzo italiano», en: Pietro Tacca. Carrara, la Toscana, le grandi corti europee, (FAllet TI, ed.), 2007, pp. 54-73. 